\title{
AN EVALUATION OF THE BEDROCK AQUIFER SYSTEM IN NORTHEASTERN WISCONSIN
}

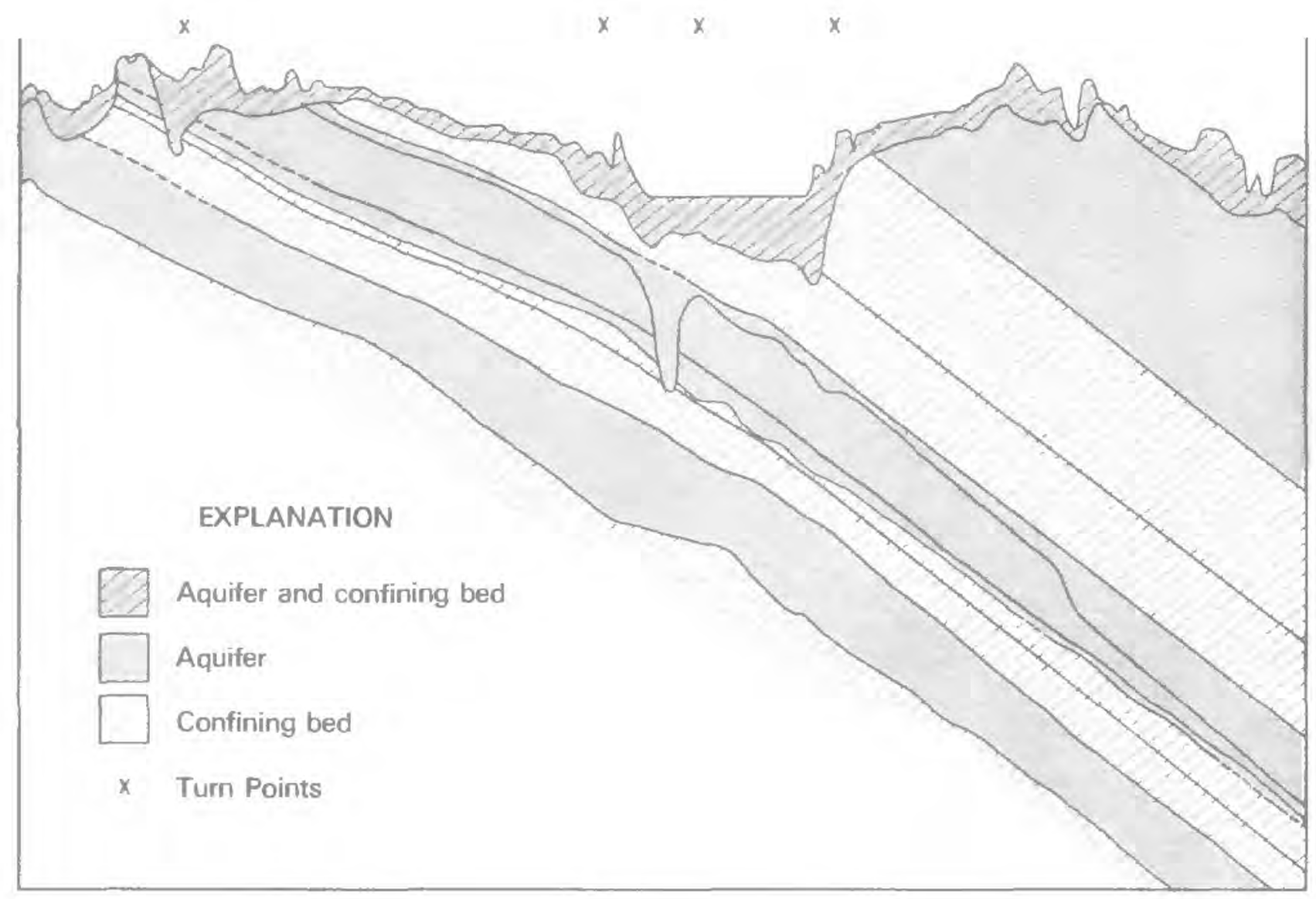




\section{AN EVALUATION OF THE BEDROCK AQUIFER SYSTEM IN NORTHEASTERN WISCONSIN}

By

Patrick J. Emmons

Water-Resources Investigations Report 85-4199

Prepared by

UNITED STATES DEPARTMENT OF THE INTERIOR GEOLOGICAL SURVEY

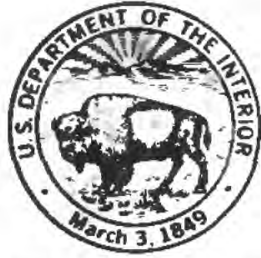

Madison, Wisconsin

1987 


\section{UNITED STATES DEPARTMENT OF THE INTERIOR DONALD PAUL HODEL, Secretary}

GEOLOGICAL SURVEY

Dallas L. Peck, Director

For additional information write to:

District Chief

U.S. Geological Survey

6417 Normandy Lane

Madison, Wisconsin 53719
Copies of this report can be purchased from:

Open-File Services Section Western Distribution Branch U.S. Geological Survey Box 25425, Federal Center Lakewood, Colorado 80225 Telephone: (303) 234-5888 


\section{CONTENTS}

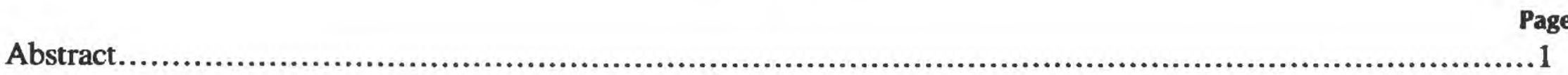

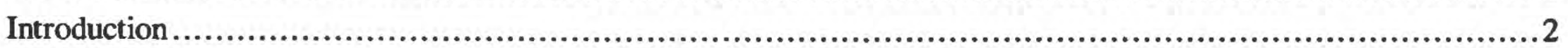

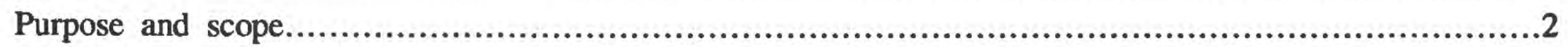

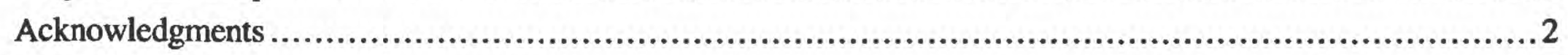

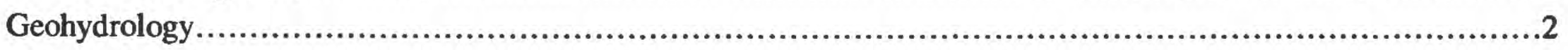

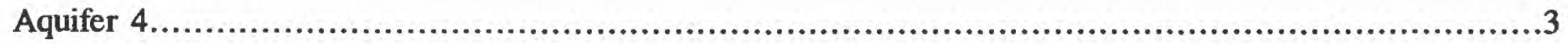

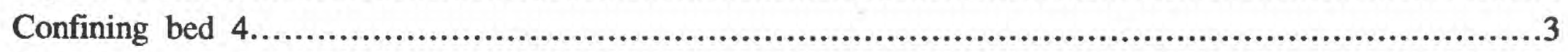

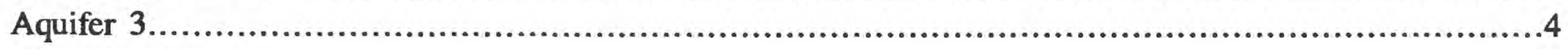

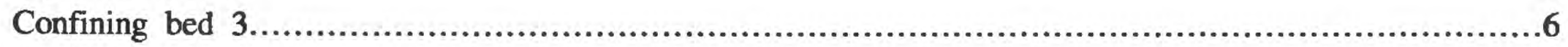

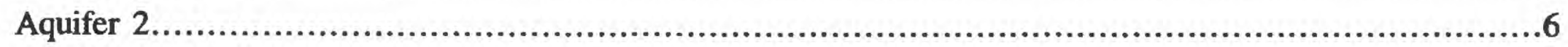

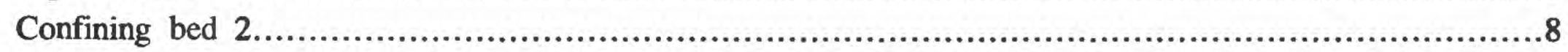

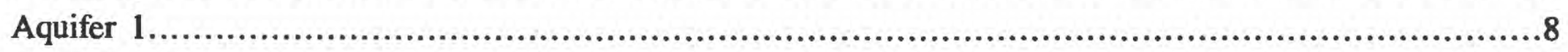

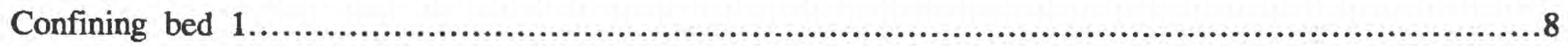

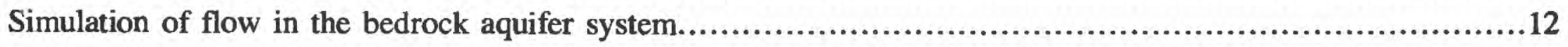

The conceptual model..................................................................................... 12

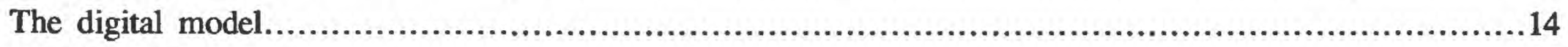

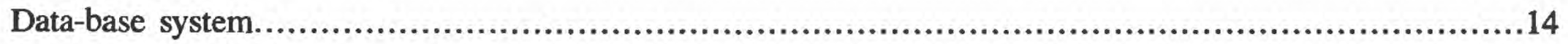

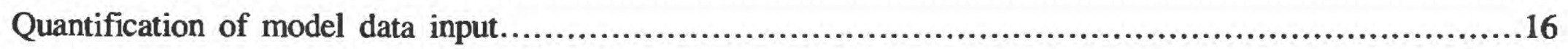

Dimensions of the finite-difference grid...............................................................16

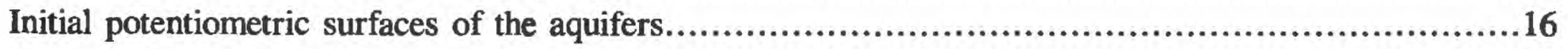

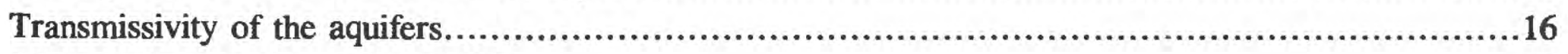

Storage coefficients of the aquifers....................................................................... 18

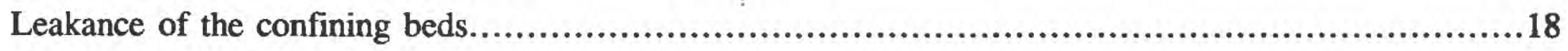

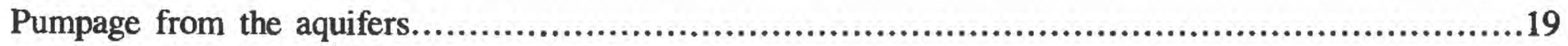

Calibration and application of the ground-water-flow model....................................................19

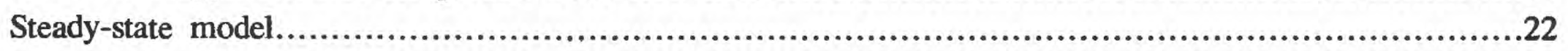

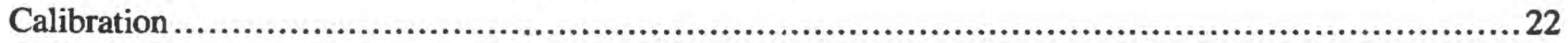

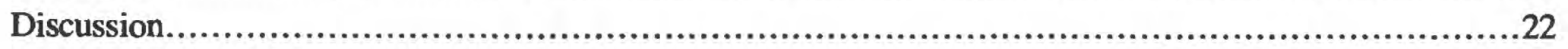

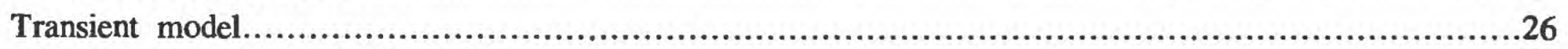

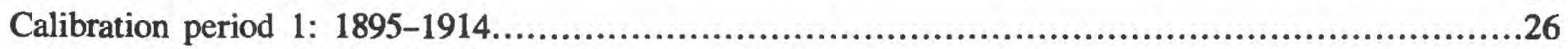

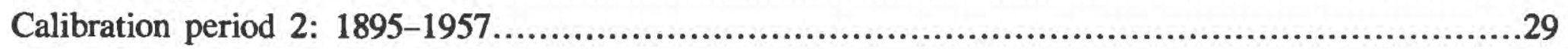

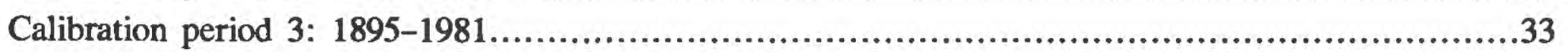

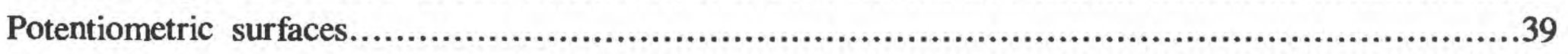

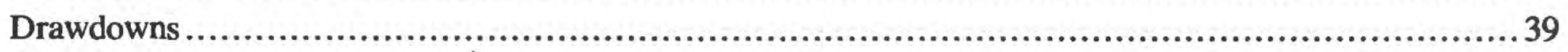

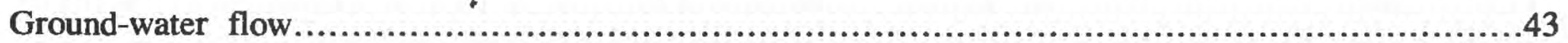

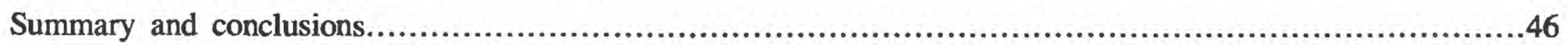

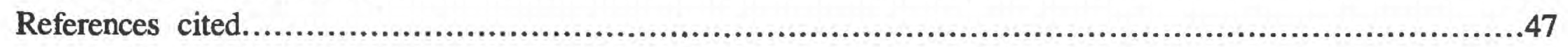




\section{ILLUSTRATIONS}

Figure 1-8. Maps showing:

1. Location of study area.

2. Thickness of the surficial deposits

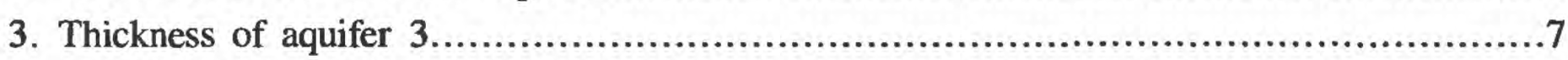

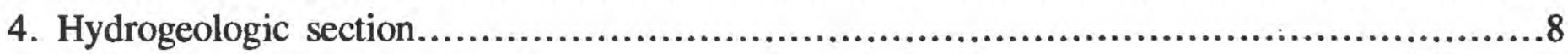

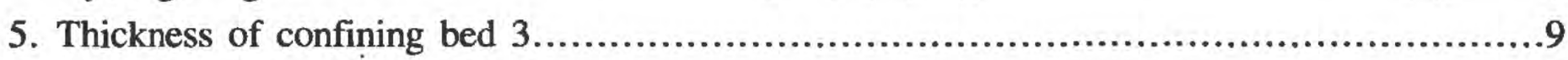

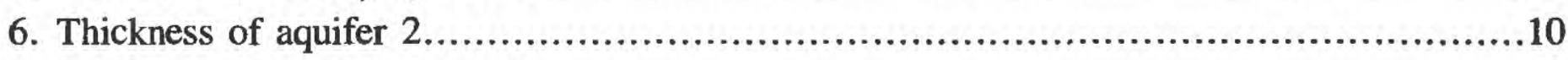

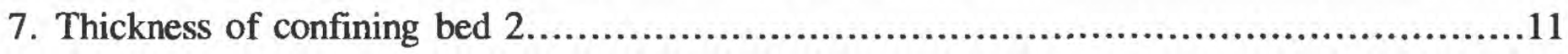

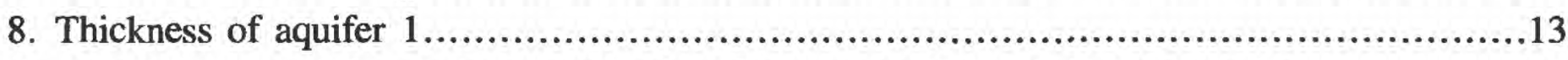

9. Schematic diagram of the study area showing the superposition of the four aquifer layers and the location of specified-head nodes and no-flow boundaries..........................14

10-19. Maps showing:

10. Finite-difference grid used to model ground-water flow in the study area....................15

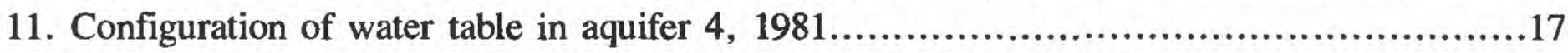

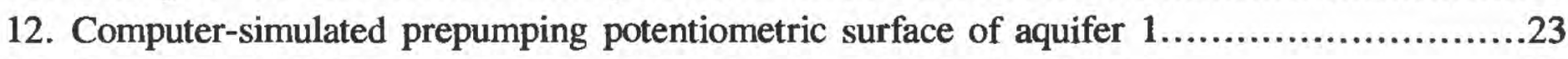

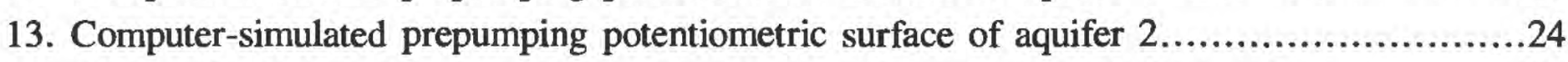

14. Prepumping vertical water movement between aquifer 1 and overlying aquifer...............25

15. Prepumping vertical water movement between aquifer 2 and overlying aquifer...............27

16. Computer-simulated composite potentiometric surface of aquifers 1 and $2,1914 \ldots \ldots \ldots \ldots . .28$

17. Computer-simulated composite potentiometric surface of aquifers 1 and $2,1957 \ldots \ldots \ldots \ldots . . .30$

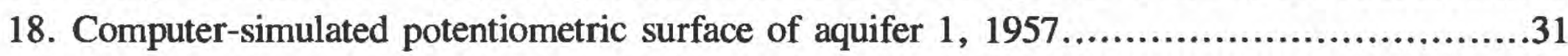

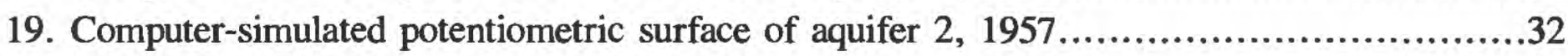

20. Selected hydrographs used for model calibration...............................................34

21-28. Maps showing:

21. Computer-simulated composite potentiometric surface of aquifers 1 and $2,1981 \ldots \ldots \ldots \ldots . .36$

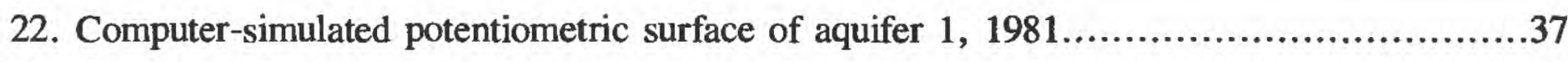

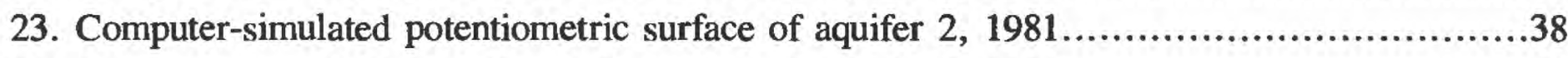

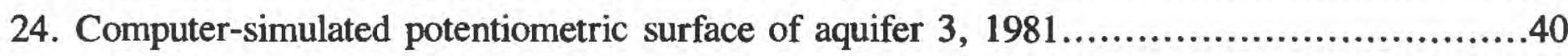

25. Computer-simulated drawdown of the potentiometric surface of aquifer 1 , prepumping through 1981.

26. Computer-simulated drawdown of the potentiometric surface of aquifer 2 , prepumping through 1981 .

27. Vertical water movement between aquifer 1 and overlying aquifer........................44

28. Vertical water movement between aquifer 2 and overlying aquifer.........................45

\section{TABLES}

Table

1. Stratigraphy and water-yielding characteristics of model units

2. Specific capacities from inflatable packer tests at Greenleaf and Marinette, Wis..............12

3. Estimated ground-water pumpage, northeastern Wisconsin, 1895-1981.......................20

4. Comparison between the model-computed potentiometric heads and measured water levels 


\section{FACTORS FOR CONVERTING INCH-POUND TO METRIC (SI) UNITS}

For readers who prefer to use metric (International System) units rather than the inch-pound units used in this report, conversion factors are listed below.

\section{Multiply inch-pound unit}

foot $(\mathrm{ft})$

square feet per day

$\left(\mathrm{ft}^{2} / \mathrm{d}\right)$

foot per day $(\mathrm{ft} / \mathrm{d})$

gallon per minute (gal/min)

inch (in.)

mile (mi)

million gallons per day

(Mgal/d)

million gallons per year

(Mgal/yr)
By

0.305

0.093

0.305

0.063

25.4

1.61

0.044

16.0

\section{To obtain SI unit}

meter (m)

square meter per day

$\left(\mathrm{m}^{2} / \mathrm{d}\right)$

meter per day $(\mathrm{m} / \mathrm{d})$

liter per second $(\mathrm{L} / \mathrm{s})$

millimeter (mm)

kilometer $(\mathrm{km})$

cubic meter per second $\left(\mathrm{m}^{3} / \mathrm{s}\right)$

cubic meter per second $\left(\mathrm{m}^{3} / \mathrm{s}\right)$

\section{DATUM}

Sea level: In this report "sea level" refers to the National Geodetic Vertical Datum of 1929 (NGVD of 1929)-a geodetic datum derived from a general adjustment of the first-order level nets of both the United States and Canada, formerly called "Mean Sea Level of 1929." 


\title{
AN EVALUATION OF THE BEDROCK AQUIFER SYSTEM IN NORTHEASTERN WISCONSIN
}

\author{
By \\ Patrick J. Emmons
}

\begin{abstract}
Ground water is a major source of water in northeastern Wisconsin. The lower Fox River valley, located between Lake Winnebago and Green Bay in northeastern Wisconsin, is the second largest population center in Wisconsin. By 1957, ground-water withdrawals had lowered the potentiometric surface of the aquifer system as much as 440 feet below prepumping levels. With the exception of the city of Green Bay, which converted from ground water to surface water (Lake Michigan) for their municipal water supply in 1957, ground-water withdrawals have continually increased.

The report evaluates the bedrock aquifer system in northeastern Wisconsin and describes how the flow regimes in the system have been altered due to ground-water withdrawals. A three-dimensional finite-difference groundwater flow model was used to aid in evaluation of the regional flow system. In order to simplify the study of the aquifer system, the geologic units were grouped into eight geohydrologic units consisting of four aquifers and four confining beds. The aquifers are the more permeable sand and gravel layers in the surficial deposits (aquifer 4), Devonian dolomite-Silurian dolomite (aquifer 3), St. Peter SandstonePrairie du Chien Group-Jordan Sandstone Member of the Trempealeau Formation (aquifer 2), and the Galesville Sandstone-Eau Claire Sandstone-Mount Simon Sandstone (aquifer 1). The confining beds are the less permeable silts and clays in the surficial deposits (confining bed 4), Maquoketa Shale-Galena Dolomite-Decorah Shale-Platteville Formation (confining bed 3), St. Lawrence Member of the Trempealeau Formation-Franconia Sandstone (confining bed 2 ), and the Precambrian crystalline rock (confining bed 1 ).

The following aquifer and confining-bed characteristics were determined to represent the aquifer system of north-

eastern Wisconsin and were used in the development of the model. Aquifer 4 acts as an upper boundary of the bedrock aquifer system. The hydraulic conductivity of aquifer 3 was 7.9 feet per day and the storage coefficient was estimated to be 0.01 . Transmissivity input values to the model for aquifer 2 are based on hydraulic conductivities ranging from 3 to 8 feet per day. The storage coefficient for aquifer 2 was 0.0002 . The transmissivity input values to the model for aquifer 1 are based on hydraulic conductivities ranging from 2.5 to 8 feet per day and the storage coefficient was 0.0002 . Confining bed 4 acts as an upper confining unit for the underlying bedrock aquifers. A vertical hydraulic conductivity of 0.007 foot per day was assigned to represent confining bed 4 . The vertical hydraulic conductivity of confining bed 3 was assigned values of 0.0001 to 0.000004 foot per day. A value of 0.00001 foot per day was used as the vertical hydraulic conductivity for confining bed 2 . Confining bed 1 is a lower boundary of the system and was not modeled.

Model simulations indicate that, by 1914 , ground-water withdrawals from the aquifer system had already impacted the study area. Pumping in the Green Bay metropolitan area had lowered the potentiometric heads in aquifer 1 by 69 feet and in aquifer 2 by 55 feet. Model simulations indicate that, by 1981 , ground-water withdrawals have caused a cone of depression centered in the city of De Pere area. The influence of the cone affects almost the entire study area and has significantly altered the horizontal and vertical flow regimes in the aquifer system. In 1981, computed drawdowns below the prepumping potentiometric surface of aquifer 1 range from 0 feet on the western side of the study area to 330 feet in the center of the cone of depression. In aquifer 2, the computed drawdown ranges from 0 feet on the western side of the study area to 253 feet in the center of the cone.
\end{abstract}




\section{INTRODUCTION}

The U.S. Geological Survey's national Regional Aquifer System Analysis (RASA) Program is conducting systematic hydrologic investigations of a number of regional groundwater systems. The major objective of the RASA program is to assemble hydrologic information and create predictive capabilities necessary for the effective management of the nation's ground water (Bennett, 1979).

Sandstone and dolomite strata of Cambrian and Ordovician age form a major aquifer system in the northern Midwest. As part of the national RASA program, a 4-year investigation of this aquifer system began in October 1978. This investigation was headed by a central project staff located in Madison, Wis. The Northern Midwest RASA study area, which is shown in figure 1 , includes parts of Wisconsin, Iowa, Illinois, Indiana, Minnesota and Missouri. The central project supported subprojects in each of the U.S. Geological Survey's District offices in the project area (Steinhilber and Young, 1979). This report describes the results of one of these subprojects: an evaluation of the bedrock aquifer system in northeast Wisconsin.

The lower Fox River Valley, located between Lake Winnebago and Green Bay in northeastern Wisconsin, is the second largest population center in Wisconsin with a population of more than 300,000 . By 1957 , continued ground-water withdrawals had lowered the potentiometric surface of the aquifer system as much as $440 \mathrm{ft}$ below its prepumping levels. In 1957, the city of Green Bay converted from ground water to surface water (Lake Michigan) for their municipal water supply. As a result, ground-water withdrawals decreased from about 13.1 to about $5.3 \mathrm{Mgal} / \mathrm{d}$ in the Green Bay area and by 1960, the potentiometric surface near the center of the drawdown cone had recovered about $240 \mathrm{ft}$ (Knowles and others, 1964). Increased demand for ground water since 1957 has resulted in renewed declines in the water levels in the partially recovered Green Bay-area-drawdown cone and continued drawdown in other parts of the study area.

\section{Purpose and Scope}

This report describes results of a study designed to evaluate the bedrock aquifer system in northeastern Wiscon$\sin$. Specifically, it describes the hydrologic and geologic characteristics of the rock units and the relationships between the aquifers and confining beds in the ground-water-flow system. Also, it provides an evaluation of the horizontal and vertical flow regimes and describes how these flow regimes have been altered due to stresses applied to the system. The report also describes the development and calibration of a three-dimensional ground-water-flow model of northeastern Wisconsin that was developed to aid in the evaluation of the bedrock aquifer system.

Hydrologic and geologic data were used from about 2,000 well records in the U.S. Geological Survey Ground Water Site Inventory (GwSI) data base and from other miscellaneous sources. Aquifer tests with inflatable packers were conducted on two wells to determine the aquifer characteristics of the individual geohydrologic units penetrated by the wells. Ground-water-withdrawal data by aquifer were compiled from Wisconsin Department of Natural Resources and Wisconsin Public Service Commission records, industrial pumpage records, and from other published and unpublished records. In order to handle this large quantity of data, the data-base management system developed by the Northern Midwest RASA study group was used (Kontis and Mandle, 1980). Programs of this data-base management system were used to computer generate a series of hydrologic and geologic maps and to digitize the input data necessary to develop a three-dimensional ground-waterflow model of the aquifer system in northeastern Wiscon$\sin$. Simulation of the aquifer system was made using the three-dimensional finite-difference, ground-water-flow model of Trescott (1975) with modifications by Trescott and Larson (1976).

\section{Acknowledgments}

The author wishes to thank the village of Greenleaf and the cities of Marinette, Wis., and Menominee, Mich., for allowing geophysical logs to be made and inflatable-packer tests to be run on their wells. Thanks are extended to Lowell Johnson and Raymond Weber of Foth and Van Dyke and Associates, Inc., for their help in locating and providing technical assistance and data on wells for packer testing.

\section{GEOHYDROLOGY}

Ground water is a major source of water in northeastern Wisconsin. The recharge, movement, and discharge of the ground water is controlled by the lithology and stratigraphy of the geologic units (table 1). In descending order, the geologic units are the surficial deposits, Devonian dolomite, Silurian dolomite, Maquoketa Shale, Galena Dolomite, Decorah Shale, Platteville Formation, St. Peter Sandstone, Prairie du Chien Group, Jordan Sandstone Member and St. Lawrence Member of the Trempealeau Formation, Franconia Sandstone, Galesville, Eau Claire, and Mount Simon Sandstones, and Precambrian crystalline rock. For purposes of this report, these rock units have been grouped into eight geohydrologic units consisting of four aquifers and four confining beds. This grouping is a logical division, hydrologically, and is the one used for modeling ground-water flow. The aquifers are the surficial deposits, Devonian dolomiteSilurian dolomite, St. Peter Sandstone-Prairie du Chien Group-Jordan Sandstone Member of the Trempealeau Formation, and the Galesville Sandstone-Eau Claire SandstoneMount Simon Sandstone. The confining beds are the surficial deposits, Maquoketa Shale-Galena Dolomite-Decorah Shale-Platteville Formation, St. Lawrence Member of the Trempealeau Formation-Franconia Sandstone, and the Precambrian crystalline rock. The lithology and water- 


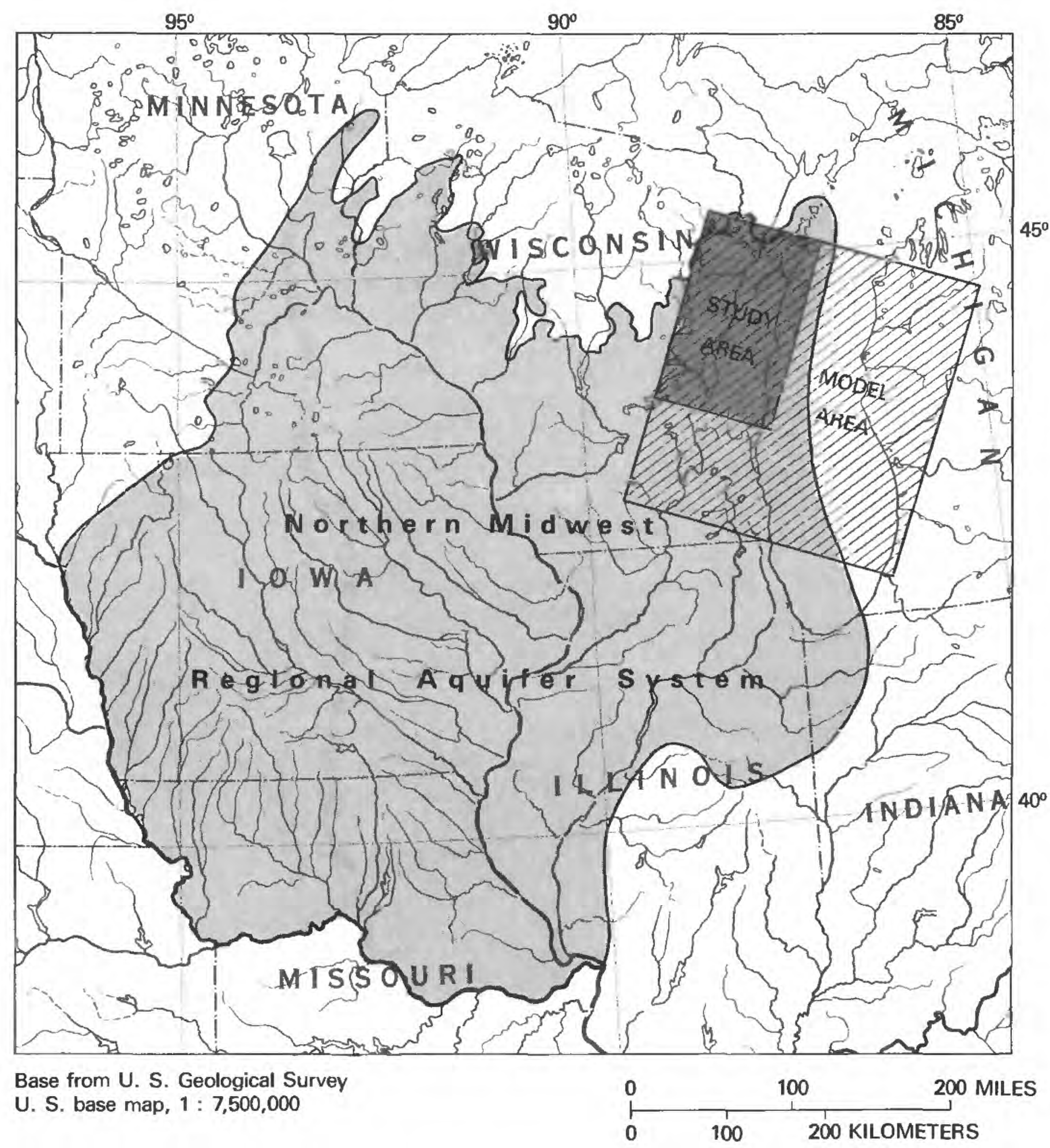

Figure 1. Location of study area.

yielding characteristics of each of the units have been summarized in table 1.

The following are descriptions of aquifer-and confiningbed model units from top to bottom.

\section{Aquifer 4}

Aquifer 4 consists of the more permeable sand and gravel layers in the surficial deposits. Surficial deposits of Quaternary age, which are found throughout the study area, include all of the unconsolidated material between the bedrock and land surface. These deposits are composed mainly of glacial drift with some alluvial and aeolian deposits. Glacial drift consists of stratified and unstratified, sorted and unsorted, clay, silt, sand, gravel, boulders, peat, and marl. The alluvial material consists of clay, silt, sand, and gravel deposited along stream channels. Aeolian deposits consist of silt and sand. The surficial deposits range in thickness from 0 to about
$600 \mathrm{ft}$. The thickest deposits are present in preglacial bedrock valleys and the thinnest where the bedrock surface is high. The thickness of the surficial deposits is shown in figure 2 .

Yields from wells finished in surficial deposits generally range from 10 to $100 \mathrm{gal} / \mathrm{min}$ in most of the study area. Where surficial deposits consist predominantly of sand and gravel and are of sufficient thickness and extent, they provide well yields up to $500 \mathrm{gal} / \mathrm{min}$. The water in the surficial deposits generally is under water-table conditions except where laterally extensive clay layers are present. In these areas, the water beneath the clay layers may be confined, producing potentiometric heads above land surface.

\section{Confining Bed 4}

Confining bed 4 consists of the less permeable silts and clays in the surficial deposits. The surficial deposits, which are found throughout the study area, include all of the un- 
consolidated material between the bedrock and land surface. These deposits are composed mainly of glacial drift with some alluvial and aeolian deposits. A more detailed description of the lithologic composition and thickness of the surficial deposits is presented in the preceding section "Aquifer 4." The thickness of the surficial deposits is shown in figure 2 .

The clay and silt in the surficial deposits generally confine the water in the underlying bedrock aquifers. The clay and silt may also act to confine the water in the surficial deposits if the clay and silt is of sufficient lateral extent and thickness.

\section{Aquifer 3}

Aquifer 3 includes the Devonian dolomite and the Silurian dolomite. The Devonian dolomite, which overlies the Silurian dolomite, is found only along the shoreline of Lake Michigan in Sheboygan and Ozaukee Counties. The Devonian is a dolomite containing shaly limestone and shale

Table 1. Stratigraphy and water-yielding characteristics of model units

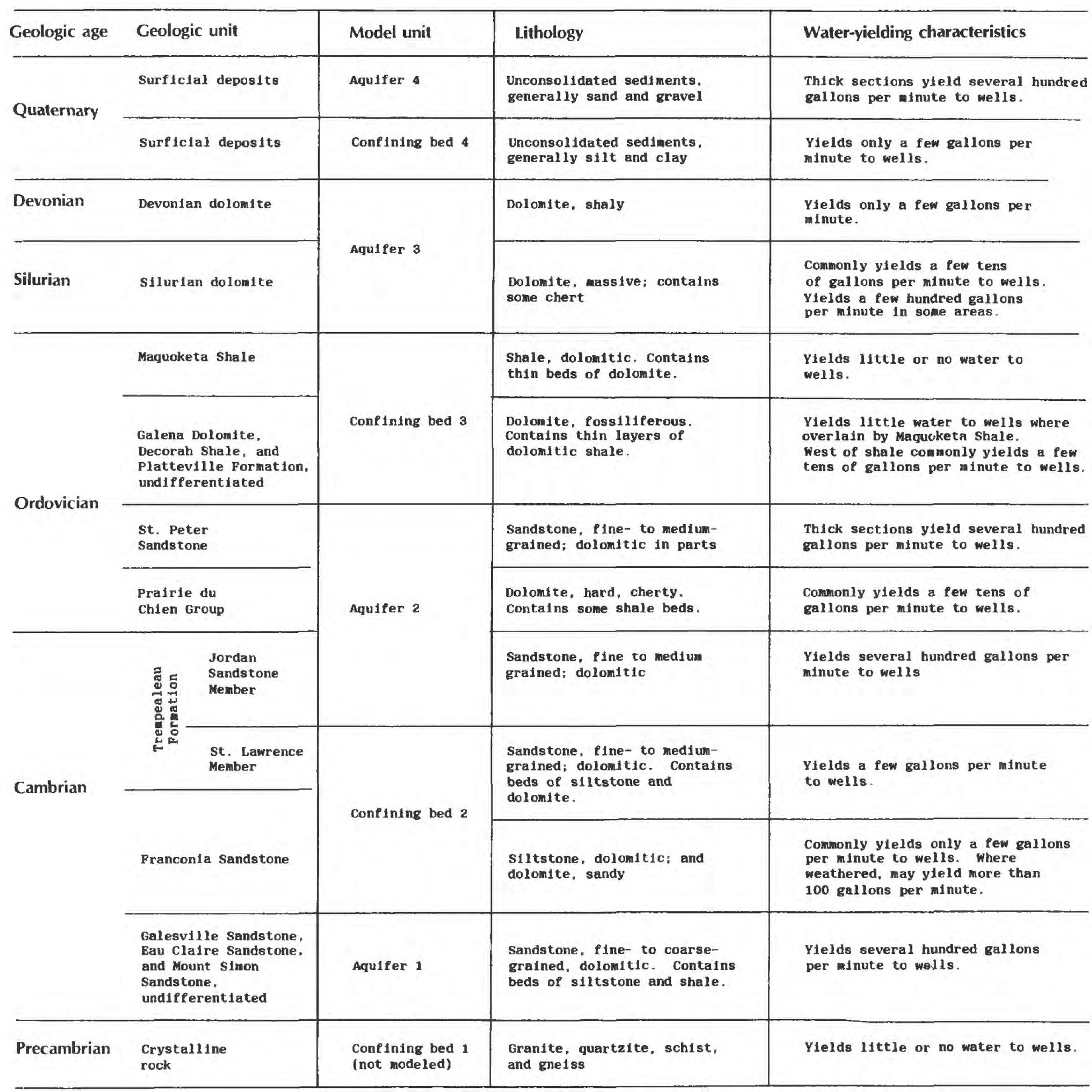




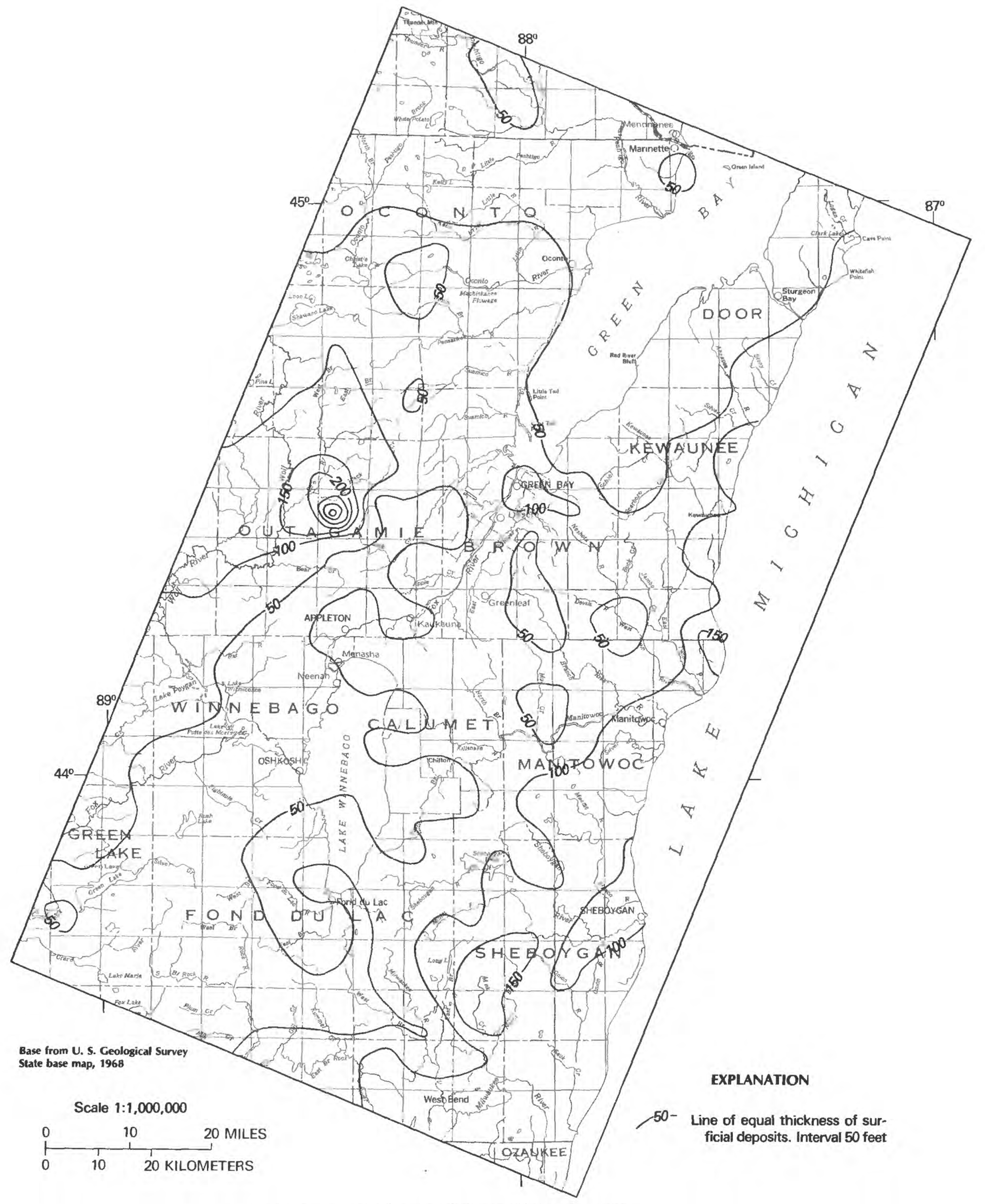

Figure 2. Thickness of the surficial deposits. 
and generally yields less than $10 \mathrm{gal} / \mathrm{min}$ to wells. The Devonian dolomite has a similar lithology and is often not distinguished from the underlying Silurian dolomite. The Silurian dolomite is found only in the eastern part of the study area, as shown in figure 3; it overlies the Maquoketa Shale.

The Silurian is a rather massive, light-gray dolomite that contains minor chert. The unit, which forms a prominent topographic escarpment along much of its erosional western edge, dips gently to the east as shown in figure 4 . The thickness averages about $400 \mathrm{ft}$. However, more than 900 $\mathrm{ft}$ of dolomite may be present along part of the eastern edge of the study area.

Most of the hydraulic conductivity of the dolomite is due to secondary rock openings such as joints, fractures, and bedding planes that have been enlarged through solution by circulating water. Well yields are also a function of the number and size of fractures the well intersects, and range from about 5 to $600 \mathrm{gal} / \mathrm{min}$. Values of hydraulic conductivity ranging from 0.017 to $8,000 \mathrm{ft} / \mathrm{d}$ were calculated from specificcapacity data from 875 wells completed in the Silurian dolomite. The geometric mean of the hydraulic conductivity was $7.9 \mathrm{ft} / \mathrm{d}$. The geometric mean was calculated from the $\log$ values of the hydraulic conductivities as described by Freeze (1972).

The upper part of the Silurian dolomite generally is under water-table conditions, whereas the lower part of the aquifer tends to be confined; some potentiometric heads are above land surface. The entire sequence of dolomite may be artesian where sufficient unconsolidated clay and silt overlie the unit. The storage coefficient has not been determined in the study area. However, a value of approximately 0.0003 was computed for the Silurian dolomite from several aquifer tests conducted in northern Illinois. The Silurian aquifer in northern Illinois occurs mainly under leaky artesian conditions (Csallany and Walton, 1963). In the study area, where the aquifer is under water-table, semiconfined conditions, the storage coefficient is orders of magnitude larger.

\section{Confining Bed 3}

The Ordovician Maquoketa Shale, Galena Dolomite, Decorah Shale, and Plattevlle Formation have been grouped together as confining bed 3. The Maquoketa Shale is a bluishgray, soft dolomitic shale, containing some thin beds of gray dolomite. The shale is found only in the eastern half of the study area and dips gently to the east as do all of the sedimentary bedrock units (fig. 4). Due to its soft, easily erodable character, the Maquoketa Shale does not extend much beyond the western edge of the overlying protective Silurian dolomite. The shale varies in thickness from 0 to more than $500 \mathrm{ft}$. Figure 5 shows the thickness of confining bed 3 . The thickest sequence is found in the northeastern part of the study area.
The undifferentiated Galena Dolomite, Decorah Shale, and Platteville Formation are predominantly thin to massive bedded, light-gray to bluish-gray, fossiliferous dolomite with some thin-bedded dolomitic shale layers. These rocks that cover approximately the eastern 70 percent of the study area vary in thickness from 0 to approximately $300 \mathrm{ft}$. Where not thinned by erosion, the average thickness is about $200 \mathrm{ft}$.

The Maquoketa Shale and the undifferentiated GalenaDecorah-Platteville unit act as a confining bed. However, in the upper part of the undifferentiated unit, fractures, joints, and bedding planes have been enlarged by solution action, and wells may yield small to moderate quantities of water. In the lower, less permeable part, and to the east, where the entire undifferentiated unit has been protected by the overlying shale, it yields little or no water to wells. The Maquoketa Shale also yields little water and is commonly cased off to prevent the shale from caving into the wells.

\section{Aquifer 2}

The St. Peter Sandstone and Prairie du Chien Group of Ordovician age and the Jordan Sandstone Member of the Trempealeau Formation of Cambrian age have been combined into aquifer 2 for this study. The St. Peter Sandstone is a fine-to-medium grained, white-to-light gray, sandstone and dolomitic sandstone. In some areas, the lower part contains dolomitic shale. The St. Peter Sandstone, which has a fairly even upper surface, was deposited on the highly eroded Prairie du Chien Group or on the underlying Jordan Sandstone and St. Lawrence Members of the Trempealeau Formation, or on the Franconia Sandstone. The thickness of the St. Peter is, therefore, extremely variable over fairly short distances as shown in figure 4.

The Prairie du Chien Group is a light-gray to white, hard, cherty dolomite with irregular and discontinuous 0.5 -in.-to 2 -ft-thick beds. The unit contains thin sand and green-shale beds. Erosion of the Prairie du Chien rocks has made their thickness very irregular.

The Jordan Sandstone Member of the Trempealeau Formation consists of light-gray, fine-to-medium grained, dolomitic sandstone.

The combined thickness of the St. Peter, Prairie du Chien, and Jordan rocks varies from 0 to $300 \mathrm{ft}$ (fig. 6). The St. Peter and Prairie du Chien units generally have a combined thickness of about $200 \mathrm{ft}$.

The hydraulic conductivity calculated from specificcapacity data for 15 wells completed in aquifer 2 ranged from 1.3 to $110 \mathrm{ft} / \mathrm{d}$. The log-normal geometric mean of the hydraulic conductivity was $10 \mathrm{ft} / \mathrm{d}$. Well yields from the aquifer are as much as $500 \mathrm{gal} / \mathrm{min}$. The aquifer is generally under artesian conditions.

Storage coefficients calculated from aquifer tests in the study area were conducted on wells open to both aquifers 1 and 2. Values of the storage coefficient range from 0.00015 to 0.014 , with an average value of about 0.0002 . There were no tests conducted on wells open only to aquifer 2 . 


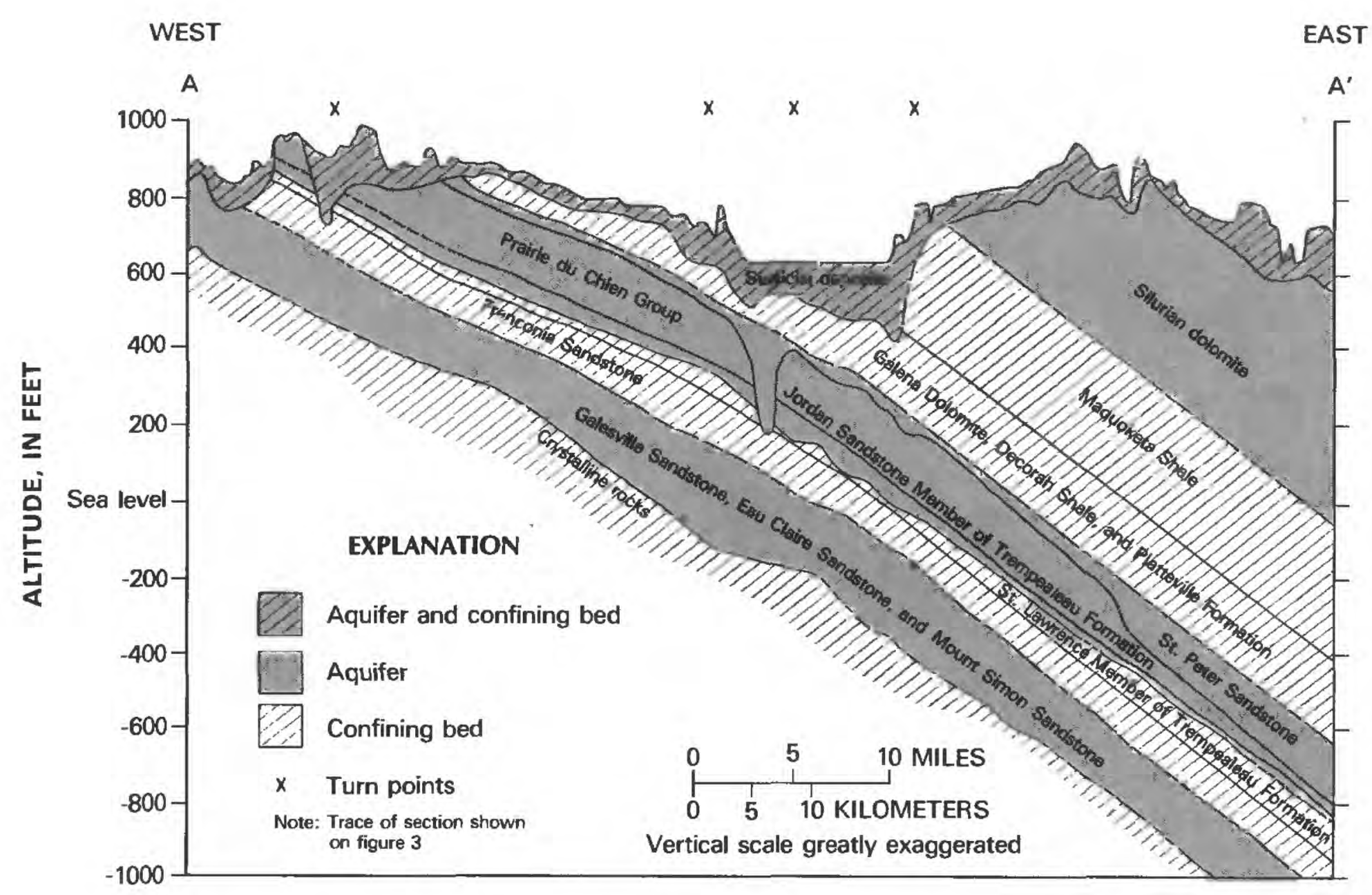

Figure 4. Hydrogeologic section.

\section{Confining Bed 2}

The St. Lawrence Member of the Trempealeau Formation and Franconia Sandstone are combined into confining bed 2 for this study. The St. Lawrence consists of gray and pink to red sandy dolomite and dolomitic siltstone. The Franconia consists of very fine-to-medium grained, light-gray and pink to green, dolomitic sandstone that contains beds of siltstone and dolomite up to $10 \mathrm{ft}$ in thickness. Figure 7 is a thickness map of confining bed 2 . The thickness of the St. Lawrence ranges from 0 to over $100 \mathrm{ft}$ and the Franconia from 0 to nearly $200 \mathrm{ft}$. However, the combined thickness generally does not exceed $200 \mathrm{ft}$.

In Fond du Lac County (Newport, 1962) and Winnebago County (Olcott, 1966), the Franconia Sandstone is capable of yielding hundreds of gallons per minute of water to wells. Lower yields are produced where the sandstone contains siltstone and dolomite layers. The high well yields would be expected where the St. Lawrence and Franconia rocks have been weathered and are in direct contact with the unconsolidated surficial deposits. Generally, the St. Lawrence and Franconia rocks yield only small quantities of water to wells. The specific capacities of the St. Lawrence and Franconia rocks are lower than those of the geohydrologic units above and below them (table 2).

\section{Aquifer 1}

The Galesville, Eau Claire, and Mount Simon Sandstones, undifferentiated, are identified as aquifer 1 in this study. The rocks consist of light-gray to white, fine-to-coarse grained, dolomitic sandstone with some thin beds of siltstone and shale. They rest unconformably on the Precambrian crystalline surface. The thickness of aquifer 1 is shown in figure 8.

The Galesville-Eau Claire-Mount Simon unit is not present just east of Lake Winnebago and west of the city of Fond du Lac due to highs in the Precambrian surface. Aquifer 1 is probably the most productive aquifer in the modeling area, yielding hundreds of gallons per minute of water to wells. The hydraulic conductivity varies from 3.5 to $160 \mathrm{ft} / \mathrm{d}$ in 28 wells completed in the aquifer. The geometric mean of the 28 hydraulic conductivity values was $10 \mathrm{ft} / \mathrm{d}$. Aquifer 1 generally is under artesian conditions except in the western part of the study area where it is the uppermost bedrock unit.

Most of the values for the storage coefficient in the study area are from wells that are open to the St. Peter-Prairie du Chien-Jordan geohydrologic unit (aquifer 2) and GalesvilleEau Claire-Mount Simon geohydrologic unit (aquifer 1). The storage coefficient ranges from 0.00015 to 0.014 , and averages about 0.0002 .

\section{Confining Bed 1}

A basement complex of dense, crystalline rocks forms the base of the ground-water system in northeastern Wisconsin and is modeled as confining bed 1 . The Precambrian crystalline rocks that have been identified in the area are chiefly granite, quartzite, schist, and gneiss. These rocks are nearly impermeable and yield little water to wells. 


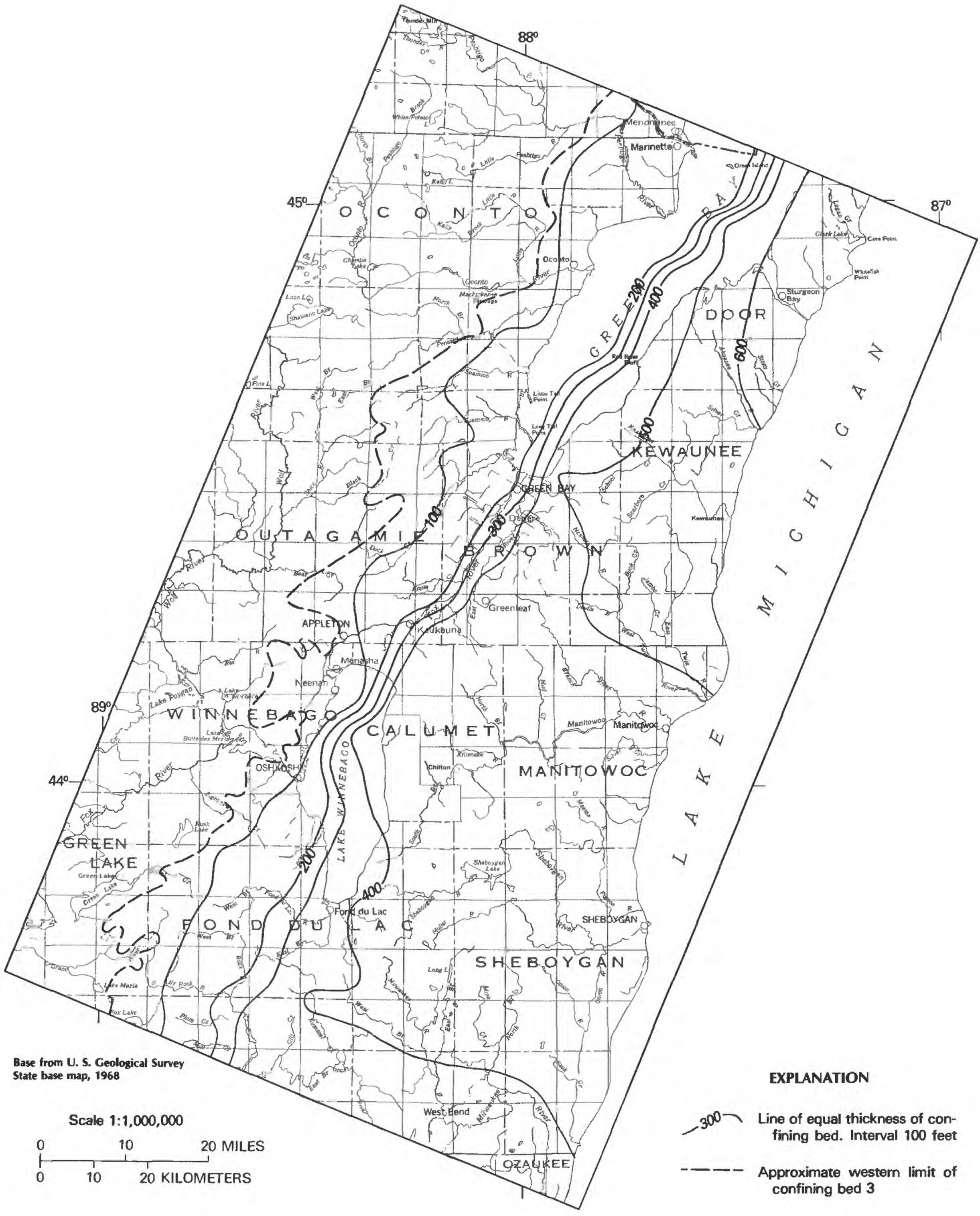

Figure 5. Thickness of confining bed 3 . 


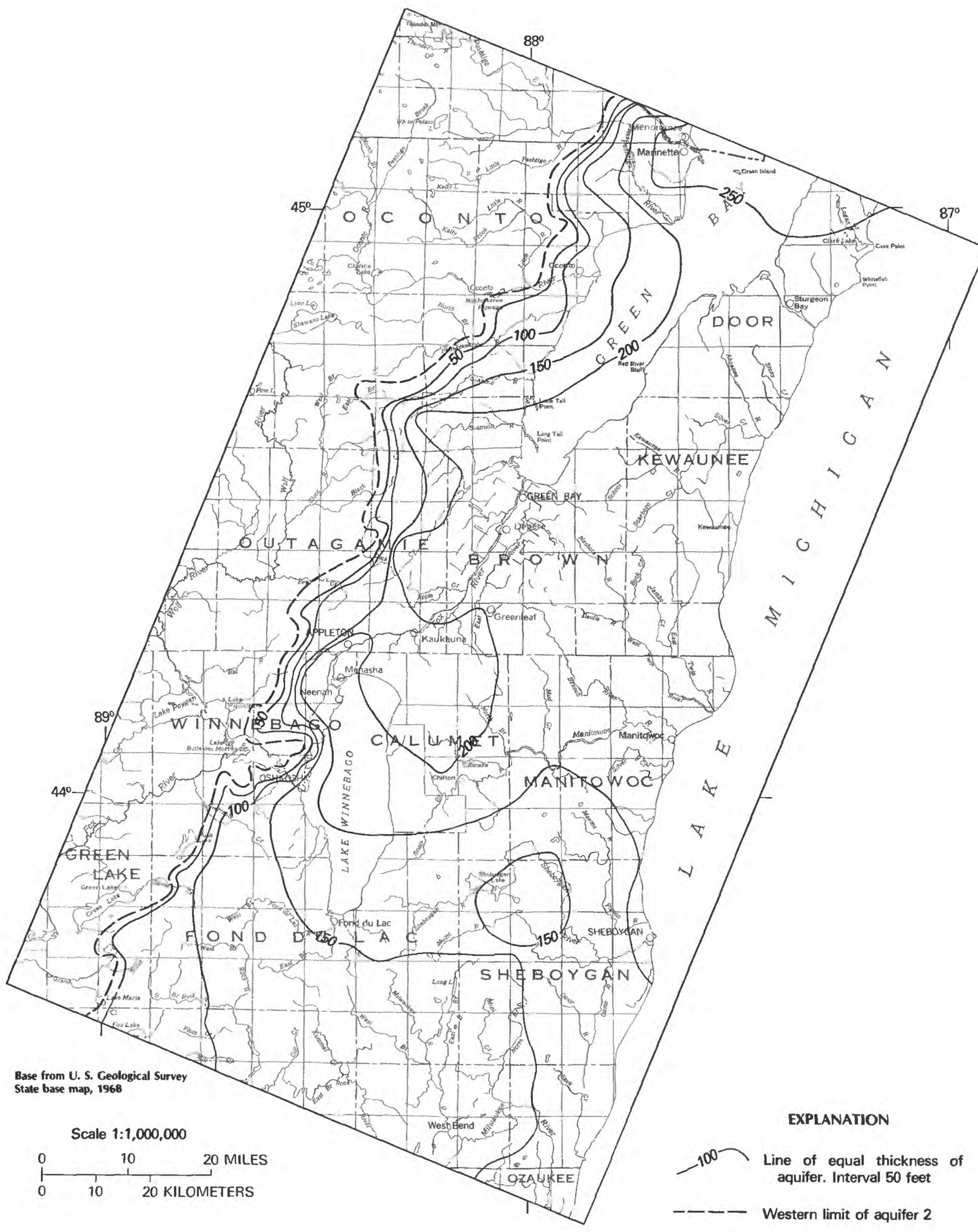

Figure 6. Thickness of aquifer 2. 


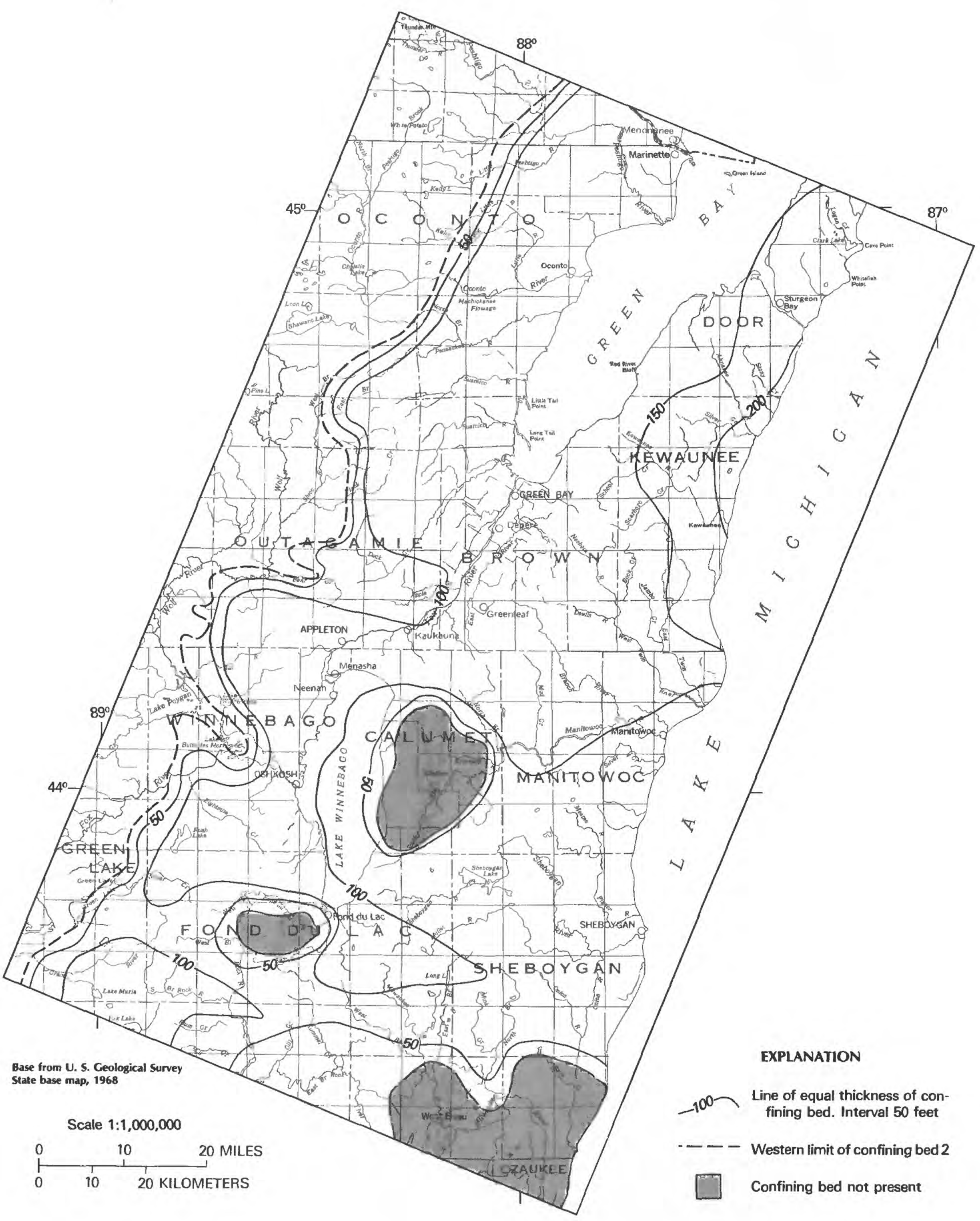

Figure 7. Thickness of confining bed 2 . 
Table 2. Specific capacities from inflatable packer tests on wells at Greenleaf and Marinette, Wis.

\begin{tabular}{|c|c|c|}
\hline \multirow[b]{2}{*}{ Geologic unit } & \multicolumn{2}{|c|}{$\begin{array}{l}\text { Specific capacity } \\
\text { (gallons per minute per foot) }\end{array}$} \\
\hline & Greenleaf well & Marinette well \\
\hline Silurian dolomite & Cased off & Not present \\
\hline Maquoketa Shale & Cased off & Not present \\
\hline $\begin{array}{l}\text { Galena Dolomite, Decorah } \\
\text { Shale, and Platteville } \\
\text { Formation, undifferentiated }\end{array}$ & 10.0 & ${ }^{1} 0.0$ \\
\hline St. Peter Sandstone & 3.9 & Not tested \\
\hline Prairie du Chien Group & Not present & ${ }^{20} 0.5$ \\
\hline $\begin{array}{l}\text { Jordan Sandstone Member of } \\
\text { the Trempealeau Formation }\end{array}$ & Not present & Not present \\
\hline $\begin{array}{l}\text { St. Lawrence Member of the } \\
\text { Trempealeau Formation }\end{array}$ & Cased off & Not present \\
\hline Franconia Sandstone & 0.1 & 20.5 \\
\hline Galesville Sandstone & 1.9 & ${ }^{3} 1.6$ \\
\hline Eau Claire Sandstone & Not drilled & ${ }^{4} 2.0$ \\
\hline Mount Simon Sandstone & Not drilled & 3.5 \\
\hline 1 Pumping dewatered packed zone. & & \\
\hline 2 Upper part Franconia Sandstone and lower Prairie du Chien. & & \\
\hline 3 Upper part of Eau Claire-Galesville, undifferentiated. & & \\
\hline 4 Lower part of Eau Claire-Galesville, undifferentiated. & & \\
\hline
\end{tabular}

\section{SIMULATION OF FLOW IN THE BEDROCK AQUIFER SYSTEM}

\section{The Conceptual Model}

Ground-water flow within an aquifer system is governed by a complex series of interrelated hydrologic processes. A conceptual model employs a number of simplifying assumptions that makes it possible to describe these hydrologic processes, allowing the aquifer system to be represented mathematically. The conceptual model is developed by analyzing existing hydrologic and geologic data. The model may not exactly represent the hydrologic processes, but includes the basic assumptions and logic governing these processes.

The basic assumptions in the conceptual model of the aquifer system in northeastern Wisconsin are:

1. The aquifer system consists of four aquifers and four confining beds (table 1 ). The aquifers are the more permeable sand and gravel layers in surficial deposits, Devonian dolomite-Silurian dolomite, St. Peter Sandstone-Prairie du Chien Group-Jordan Sandstone Member of the Trempealeau Formation, and the Galesville Sandstone-Eau Claire Sandstone-Mount Simon Sandstone. The confining beds are the less permeable silt and clay layers in surficial deposits, Maquoketa Shale-Galena Dolomite-Decorah Shale-Platteville Formation, the St. Lawrence Member of the Trempealeau Formation-Franconia Sandstone, and the Precambrian crystalline rocks.
2. The principal source of recharge to the aquifer system is precipitation. The surficial deposits are recharged directly by infiltration of precipitation. Recharge to the lower aquifers occurs where the units subcrop beneath the surficial deposits. Recharge to the lower units also can occur as leakage through the overlying confining beds. Recharge to the surficial deposits occurs throughout the study area.

3. The water table in surficial deposits can be represented as a specified-head boundary as shown in figure 9. Conceptually, the water-table aquifer in the surficial deposits provides a source of recharge to, or acts as a sink for discharge from, the underlying artesian bedrock aquifers. The silt and clay layers in the surficial deposits act as an upper confining bed for the underlying artesian bedrock aquifers.

4. All lateral model boundaries of the three bedrock aquifers are no flow except west of the aquifers' western limits where heads are held constant to represent the surficial aquifer. This area of constant head is represented by specified-head grid blocks as shown in figure 9. The northern boundary was designated no flow because the potentiometric gradients of the aquifers are approximately parallel to that boundary. The southern and eastern no-flow boundaries were placed at a sufficient distance to minimize any boundary effects in the study area (fig. 1). When compared with recharge from the overlying surficial deposits, horizontal flow across the western boundary is insignificant.

5. The Precambrian crystalline rock is an impermeable boundary of the aquifer system. 


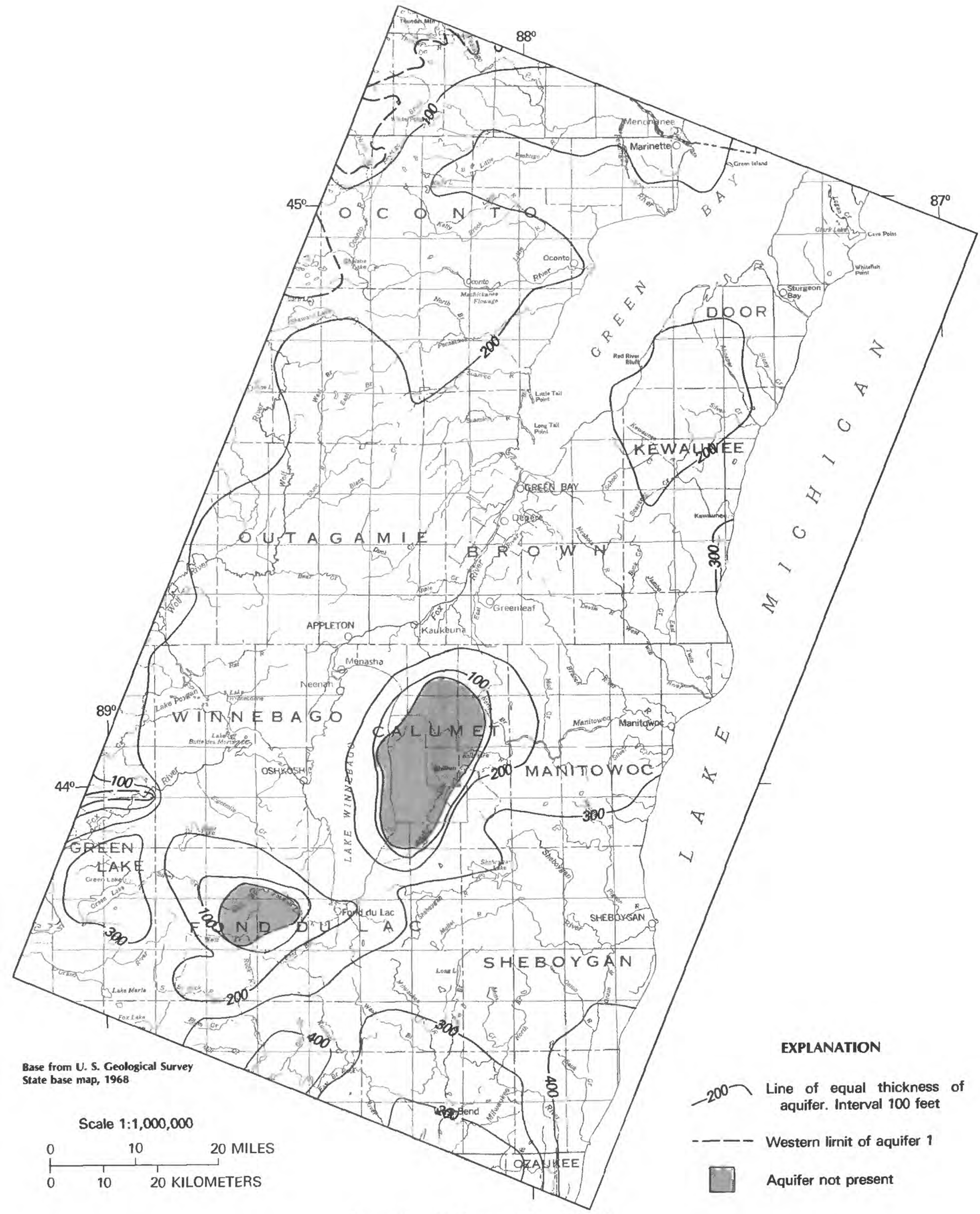

Figure 8. Thickness of aquifer 1. 
6. All of the flow in the aquifers is horizontal. All of the flow in the confining beds is vertical. Storage occurs only in the aquifers. Confining beds yield no water to wells.

7. Discharge from the bedrock aquifers occurs as pumpage or as leakage through the confining beds. Discharge from the surficial deposits occcurs as leakage to the underlying aquifers.

\section{The Digital Model}

A mathematical model of an aquifer system is the application of mathematical equations describing ground-water flow to a conceptual model of the flow system. A digitalcomputer model or simply a digital model uses a digital com-

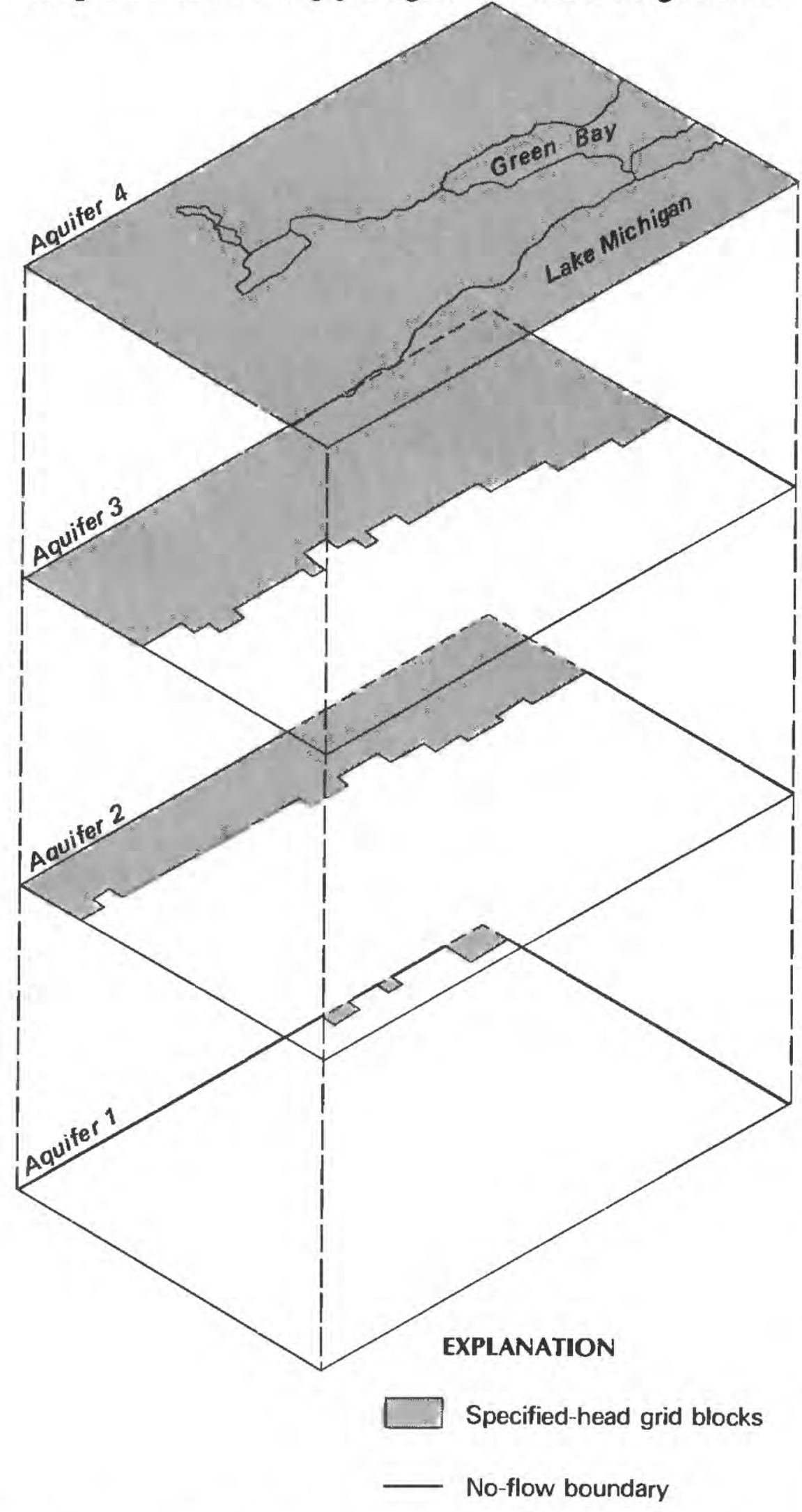

Figure 9. Schematic diagram of the study area showing the superposition of the four. aquifer layers and the location of specified-head nodes and no-flow boundaries. puter to obtain approximate solutions to the partial differential equations of ground-water flow contained in the mathematical model. The digital model used in this study is the threedimensional finite-difference ground-water flow model of Trescott (1975) with modifications (Trescott and Larson, 1976). The source-model program also was modified by the northern Midwest RASA study group to simulate the hydraulic effects of wells open to more than one aquifer in the aquifer system and to make it possible to run the model on the University of Wisconsin UNIVAC 1100/82 1 computer. The model was designed to simulate the ground-water flow in an aquifer system using either a fully three-dimensional or quasi three-dimensional approach. The three-dimensional approach requires larger computer memory and more computer time than the quasi three-dimensional approach. The quasi three-dimensional approach is a series of twodimensional models coupled by terms representing flow through the intervening confining beds. The quasi threedimensional approach can be used if horizontal flow in the confining beds and vertical flow in the aquifers can be ignored. The quasi three-dimensional approach was used to simulate the bedrock aquifer system in northeastern Wisconsin.

The modified Trescott model uses finite-difference methods to obtain approximate solutions to partial-differential ground-water-flow equations. The modeling area was subdivided into a series of finite-difference-grid blocks in which the aquifer properties are assumed to be constant (fig. 10). The continuous derivatives of the partial differential equation of ground-water flow are replaced by the finite-difference approximations at the center of each of the grid blocks, or, at the nodes. The result is a series of finite-difference equations that can be solved with the strongly-implicit-procedure (SIP) iterative-numerical technique (Trescott, 1975).

\section{Data-Base System}

The problem of producing an array of data values to input to each node in the model grid is a common one to modeling. Generally, these arrays must be produced from scattered discrete point data. Much of the point data required to develop the model of northeastern Wisconsin is contained in the U.S. Geological Survey Ground-Water Site Inventory (GWSI) data base. The data in GWSI include water-level, wellconstruction, geologic, and hydrologic data. To utilize the data in GWSI, the customary procedure has been to retrieve the data and then manually plot and contour the data. A finitedifference grid is then laid over the contoured data and an average value for the hydrologic element in each node is estimated and coded in a form which can be used as model input.

The northern Midwest RASA study group developed a data-base management system that will produce refined data which can be directly inserted into the model from discrete point data (Kontis and Mandle, 1980). Selected data in GWSI

\footnotetext{
1 The use of trade names in this report is for identification only and does not imply endorsement by the U.S. Geological Survey.
} 


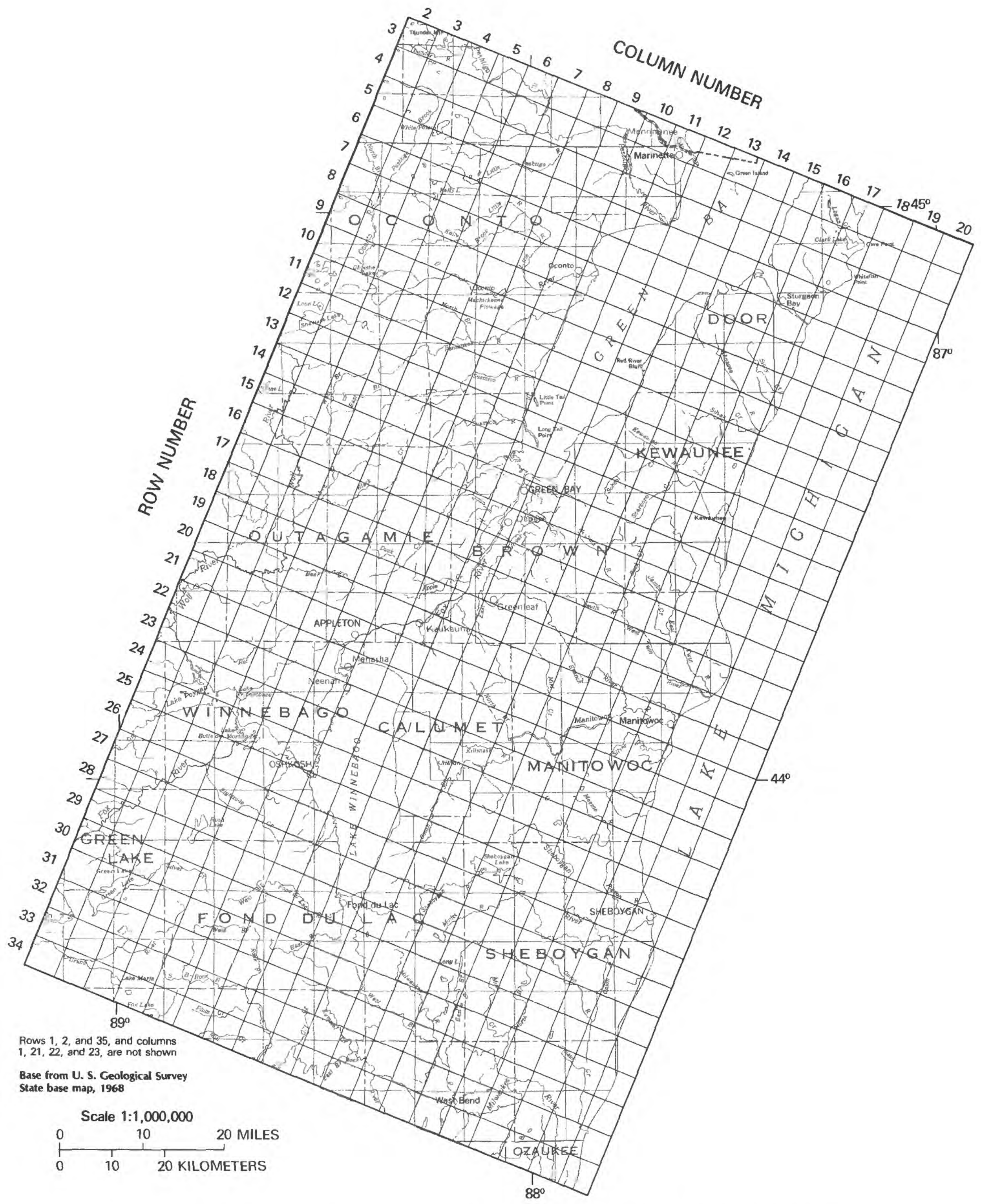

Figure 10. Finite-difference grid used to model ground-water flow in the study area. 
were transferred to temporary data files and then retrieved on to local off-line disks utilizing an Informer 3 microprocessor. The data on the disk files were edited to insure accuracy and completeness and then transferred to the University of Wisconsin UNIVAC 1100/82 computer where the RASA data-base-management-and model-source programs reside. The offline use of the microprocessor and disk files have shown to be a very effective, rapid, and low-cost means of handling and editing data.

The edited data on the computer were sorted and rearranged into the hydrologic and geohydrologic elements required for modeling. The RASA data-base-management program using a Forward-Lambert transformation technique converted the geographic latitude and longitude coordinates of the data to cartesian "map inches". By use of the minimum curvature spline (MISP) method, the unequally spaced data in map inch coordinates were converted to uniform two-dimensional grids. The accuracy of the gridded data was checked by visually comparing the machinegenerated contour maps with existing hand-contoured maps and with the actual point data.

These techniques were used to generate gridded point data for most of the elements described in the following section.

\section{Quantification of Model Data Input}

Data are input to a ground-water-flow model by entering a value for the hydrologic elements that define the system at each finite-difference node in each layer. The value assigned to the node is considered to be representative of the entire grid block. The following is a list of elements used in the model of the ground-water system in northeastern Wisconsin:

1. Dimensions of the finite-difference grid

2. Initial potentiometric surfaces of the aquifers

3. Transmissivity of the aquifers

4. Storage coefficient of the aquifers

5. Vertical leakage of the confining beds

6. Pumpage from the aquifers

\section{Dimensions of the Finite-Difference Grid}

A finite-difference grid is required so the geohydrologic data can be put in a form to be entered and operated on by the computer-model program. The finite-difference grid selected to represent the model area has 39 rows and $28 \mathrm{col}-$ umns. The finite-difference grid shown in figure 10 includes the first 35 rows and 23 columns and represents the study area shown in figure 1 . The following table shows the row and column grid spacing used in the model.

\begin{tabular}{|c|c|c|c|}
\hline $\begin{array}{l}\text { Row } \\
\text { number }\end{array}$ & $\begin{array}{c}\text { Approximate } \\
\text { grid spacing } \\
\text { (mi) }\end{array}$ & $\begin{array}{l}\text { Column } \\
\text { number }\end{array}$ & $\begin{array}{c}\text { Approximate } \\
\text { grid spacing } \\
\text { (mi) }\end{array}$ \\
\hline $1-35$ & 3.75 & $1-23$ & 3.75 \\
\hline 36 & 7.50 & 24 & 7.50 \\
\hline 37 & 15.00 & 25 & 15.00 \\
\hline 38 & 30.00 & 26 & 30.00 \\
\hline \multirow[t]{2}{*}{39} & 30.00 & 27 & 60.00 \\
\hline & & 28 & 60.00 \\
\hline
\end{tabular}

Rows 1-35 and columns 1-23 are equally spaced at $19,792 \mathrm{ft}$, producing grid blocks of about $3.75 \mathrm{mi}$ on a side. The uniform grid spacing representing the study area is small enough to define the regional flow system. The model grid was extended beyond the study area, $82.5 \mathrm{mi}$ to the south and $172.4 \mathrm{mi}$ to the east. The model boundaries were extended this far to minimize boundary effects on the study area.

\section{Initial Potentiometric Surfaces of the Aquifers}

The input array used to generate the water-table surface of aquifer 4 (fig. 11) was used as the initial potentiometricsurface array for the four aquifers in the prepumping model. More than 1,000 historical water-level measurements were used to generate this model-input array. Where aquifer 4 underlies Green Bay or Lake Michigan, the aquifer is assigned the altitude of the lake surface, $580 \mathrm{ft}$ above sea level. Also, where the aquifer underlies Lake Winnebago, the lake level of $747 \mathrm{ft}$ above sea level was assigned as the watertable altitude. The aquifer 4 water table is at or very close to its prepumping levels. Also, the potentiometric heads in aquifer 3, which have not changed appreciably due to pumping, are at or very close to the heads in aquifer 4 . Therefore the water-table array is a good representation of the initial potentiometric surfaces of aquifers 3 and 4 . Because there are no head data available to define the prepumping potentiometric surfaces in aquifers 1 and 2, the aquifer 4 water-table array also was used as an initial potentiometric surface for these aquifers in the prepumping model.

The potentiometric-head arrays of aquifers 1,2 , and 3 computed by the prepumping or steady-state model were used as the corresponding starting potentiometric-head arrays in the transient or pumping model. A discussion of the prepumping model and the prepumping potentiometric surfaces are contained in the section titled "Steady-State Model".

Because the water table in aquifer 4 is at or very close to its prepumping levels, it was also used as the specifiedhead boundary in the pumping model.

\section{Transmissivity of the Aquifers}

The transmissivity arrays used in the model were obtained by multiplying the hydraulic conductivity of the aquifer by the thickness of the aquifer at each node. Aquiferthickness arrays were generated by the technique described 


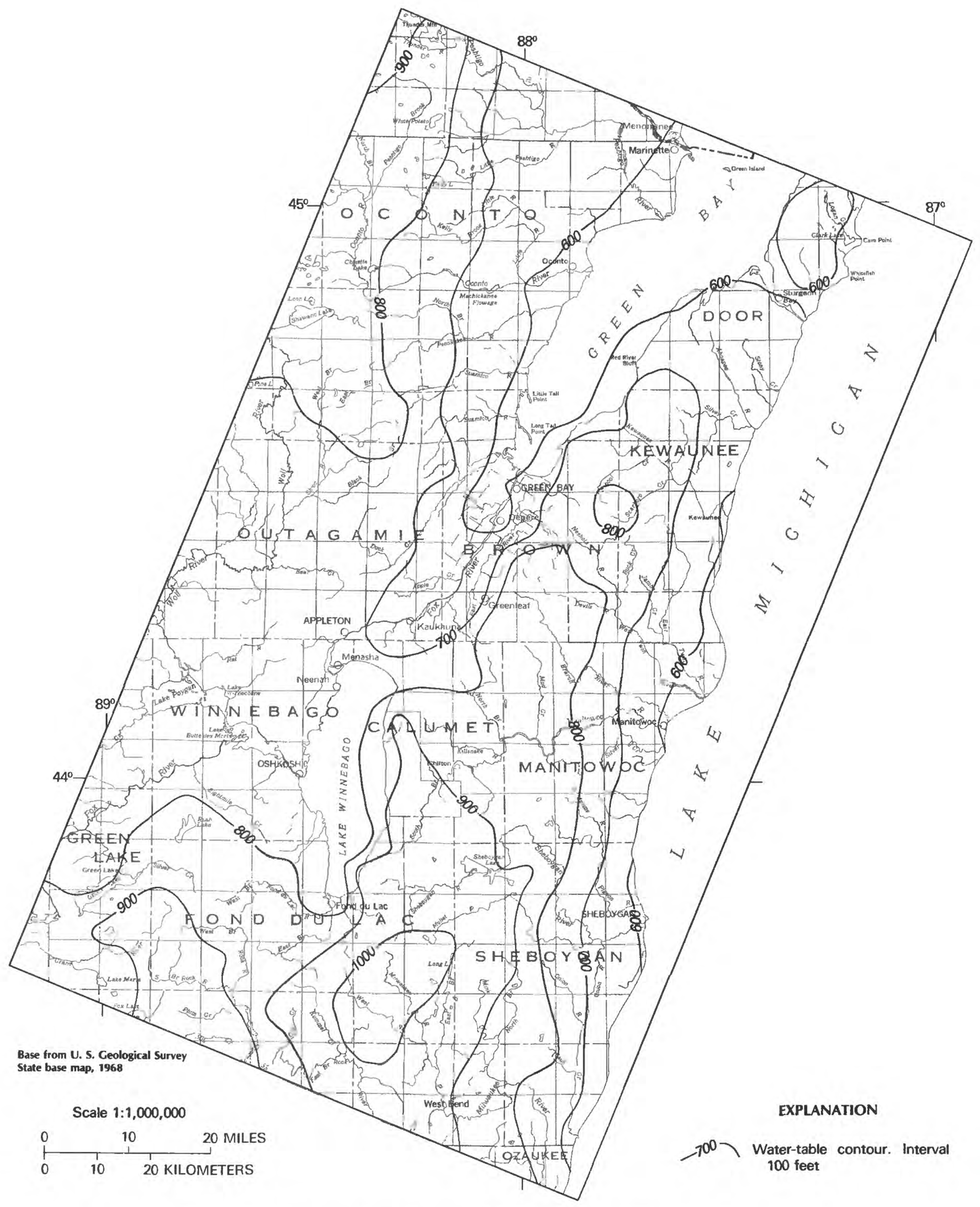

Figure 11. Configuration of water table in aquifer $4,1981$. 
earlier. Figures 8 and 6 show the general range in thickness of aquifers 1 and 2, respectively.

As mentioned previously, the geometric mean of the hydraulic conductivities calculated for aquifers 1 and 2 derived from specific-capacity tests is $10 \mathrm{ft} / \mathrm{d}$. The composite transmissivity of aquifers 1 and 2, obtained by multiplying the hydraulic conductivities times the aquifer thickness, resulted in transmissivity values much higher than those obtained from aquifer tests. Newport (1962) reported an average transmissivity value of approximately $3,400 \mathrm{ft}^{2} / \mathrm{d}$ in the city of Fond du Lac area. Olcott (1966) reported a transmissivity value of $2,700 \mathrm{ft}^{2} / \mathrm{d}$ in Winnebago County, and an average transmissivity of about $1,600 \mathrm{ft}^{2} / \mathrm{d}$ was reported for the Green Bay area (Knowles, Dreher, and Whetstone, 1964).

Because transmissivities obtained from aquifer tests are believed to be more reliable than those calculated from specific-capacity tests, the following hydraulic conductivity for aquifer 1 was reduced. As indicated on the following table, the reduction resulted in a projected hydraulic conductivity of $8.3 \mathrm{ft} / \mathrm{d}$ for the southern part of the modeled area to $3.1 \mathrm{ft} / \mathrm{d}$ for the northern part. The hydraulic conductivities of aquifer 2 were reduced to $8.2 \mathrm{ft} / \mathrm{d}$ in the southern part of the modeling area to $2.5 \mathrm{ft} / \mathrm{d}$ the north.

\begin{tabular}{|c|c|c|}
\hline $\begin{array}{c}\text { Row } \\
\text { number }\end{array}$ & $\begin{array}{c}\text { Hydraulic } \\
\text { conductivity } \\
\text { of aquifer } 1 \\
\text { (feet per day) }\end{array}$ & $\begin{array}{c}\text { Hydraulic } \\
\text { conductivity } \\
\text { of aquifer } 2 \\
\text { (feet per day) }\end{array}$ \\
\hline $1-18$ & 3.1 & 2.5 \\
\hline $19-21$ & 4.2 & 3.1 \\
\hline $22-23$ & 5.1 & 4.2 \\
\hline $24-26$ & 6.2 & 5.1 \\
\hline $27-28$ & 7.1 & 6.2 \\
\hline $29-35$ & 8.3 & 8.2 \\
\hline
\end{tabular}

The hydraulic conductivity obtained from a well finished in aquifer 3 is a function of the number and size of fractures and solution openings penetrated by the well. Values of hydraulic conductivity ranging from 0.017 to $8,000 \mathrm{ft} / \mathrm{d}$ were calculated from specific-capacity data for 875 wells completed in aquifer 3 . Although the hydraulic conductivity varies over 6 orders of magnitude, the geometric mean of $7.9 \mathrm{ft} / \mathrm{d}$ is representative of the aquifer on a regional scale. The aquifer thickness shown in figure 3 and the geometric mean of the hydraulic conductivity was used to calculate the transmissivity.

Aquifer 4 was represented as a specified-head boundary and, therefore, did not require assignment of transmissivity.

\section{Storage Coefficients of the Aquifers}

Analyses of aquifer tests indicate that the storage coefficients for aquifers 1 and 2 are approximately 0.0002 and are generally constant throughout the study area. This value for storage coefficient was used for aquifers 1 and 2 throughout the model.

Little data are available on the storage coefficient of aquifer 3 in the study area. However, the aquifer varies from unconfined to semiconfined with location and depth. A storage coefficient of 0.01 , which is a transition value between confined and unconfined aquifers, was used and gave acceptable results in the model.

Aquifer 4 is represented as a specified head and, therefore, is not assigned a value for storage.

\section{Leakance of the Confining Beds}

The leakance or leakage coefficient is the volumetric rate at which water will flow vertically from one aquifer to another through an intervening confining bed per unit area per foot of head loss between the aquifers.

The leakance arrays are calculated as the vertical hydraulic conductivity divided by the thickness of each confining bed at each node. Confining bed 1 is the lower limit of the aquifer system and was not modeled.

No quantitive data are available on the leakance through confining bed 2 in the study area. However, data from packer tests (table 2) indicate confining bed 2 probably has a higher hydraulic conductivity than confining bed 3 . If the horizontalto-vertical anisotropy in confining beds 2 and 3 are proportional, then confining bed 2 should have a higher vertical hydraulic conductivity than confining bed 3 . Through a series of model adjustments, the vertical hydraulic conductivity of $0.00001 \mathrm{ft} / \mathrm{d}$ divided by the thickness of confining bed 2 (fig. 7) was found to give acceptable results.

No data are available for the vertical hydraulic conductivity of confining bed 3 in the modeled area. However, it is assumed that it would have similar values to those in northeastern Illinois and southeastern Wisconsin. In northeastern Illinois, Walton (1960) calculated the average vertical hydraulic conductivity of the Maquoketa Shale to be about $0.000007 \mathrm{ft} / \mathrm{d}$. Young varied the vertical hydraulic conductivity of the Maquoketa Shale areally from 0.000004 to $0.00004 \mathrm{ft} / \mathrm{d}$ in a ground-water flow model of southeastern Wisconsin (Southeastern Wisconsin Regional Planning Commission, 1976). The vertical hydraulic conductivity of the Galena-Decorah-Platteville unit and the drift in the modeled area were varied areally from 0.0007 to $0.0034 \mathrm{ft} / \mathrm{d}$.

Through a series of model calibration adjustments, it was found that a vertical hydraulic conductivity of $0.000004 \mathrm{ft} / \mathrm{d}$ divided by the thickness for most of confining bed 3 provided the best match between observed and computed potentiometric heads. On the western side of the model area, where the Maquoketa Shale is not present and the Galena-DecorahPlatteville unit is less than $80 \mathrm{ft}$ thick, a vertical hydraulic conductivity of $0.0001 \mathrm{ft} / \mathrm{d}$ provided the best match between the observed and model-computed potentiometric heads. 
There are no data available for the vertical hydraulic conductivity of confining bed 4 in the study area. In northeastern Illinois, the vertical hydraulic conductivity of the drift calculated from seven aquifer tests ranged from 0.01 to 0.084 $\mathrm{ft} / \mathrm{d}$ (Walton, 1960). In developing a ground-water flow model in southeastern Wisconsin, Young used vertical hydraulic conductivity values of 0.0007 to $0.0034 \mathrm{ft} / \mathrm{d}$ for the Galena-Decorah-Platteville unit and drift in the recharge areas (Southeastern Wisconsin Regional Planning Commission, 1976). Bradbury (1982) used values of 0.004 to 0.58 $\mathrm{ft} / \mathrm{d}$ for the drift to develop a ground-water-flow model of the Silurian dolomite in Door County. A uniform vertical hydraulic conductivity of $0.007 \mathrm{ft} / \mathrm{d}$ was assigned to represent confining bed 4 .

\section{Pumpage from the Aquifers}

Data on ground-water withdrawals are required to simulate transient conditions in the model. Pumpage data were collected for the period 1895 through 1981. To simulate the transient conditions, pumpage within the study area from three aquifers or combinations of these aquifers was compiled by county for 10 pumping periods from 1895-1981 (table 3). The table indicates where and how fast pumpage has increased.

Table 3 includes high-capacity-well pumpage from aquifers 1, 2, and 3 only. The State of Wisconsin classifies a high-capacity well as one which has the capability of producing at least $100,000 \mathrm{gal} / \mathrm{d}$. Wells not capable of producing $100,000 \mathrm{gal} / \mathrm{d}$ are classified as low-capacity wells. Lowcapacity residential and farm wells were not considered as there are no accurate means of estimating well location, pumpage and aquifers penetrated by the wells. The lowcapacity wells also tend to be shallow and spread out so that there are no discernable drawdowns on the aquifers to which they are open. Aquifer 4, in which most of the low-capacity wells are finished, is in hydrologic equilibrium, with discharge equaling recharge, the water table is at or very close to its prepumping levels. Therefore, pumping from aquifer 4 was not input to the model.

Table 3 was prepared from data reported by Weidman and Schultz (1915), Wisconsin Bureau of Sanitary Engineering (1935), Wisconsin Department of Natural Resources (1970), and Donohue and Associates (1976). In addition, unpublished records by the Wisconsin Department of Natural Resources, Private and Public Water Supply Sections, Public Service Commission, and data collected by the U.S. Geological Survey for previous ground-water studies in the model area were used. The Brown County Planning Commission collected historical-pumpage data for Brown County. Where pumpage data for private industrial wells were inadequate, the Classified Directories of Wisconsin Manufacturers were used to determine location and verify a company's existence. Census data were used to determine population of counties, towns and municipalities. These data were used to assist in extrapolating industrial-and municipalpumpage data.

\section{CALIBRATION AND APPLICATION OF THE GROUND-WATER-FLOW MODEL}

Model calibration is the process by which input data are adjusted so the model will adequately simulate historical potentiometric surfaces. The initial prepumping equilibrium conditions were simulated by the model without inputting pumpage and by setting the storage coefficients of the aquifers to zero. This is referred to as the steady-state model. The computed steady-state potentiometric surfaces were compared to earliest available measured water-level data to assess the accuracy of the steady-state model. The potentiometric heads computed by the steady-state model were used as the starting potentiometric heads in the transient or pumping model. The transient model was run using historical pumpage data and the resultant potentiometric surfaces were compared to measured historical surfaces. Calibration involves varying the values of transmissivity, leakance, and storage coefficient to bring computed water levels closer to measured values. All of the parameter values were changed within reasonable limits. The model was considered calibrated when the aquifer input data was within acceptable limits and the model adequately simulated the historical potentiometric surfaces.

Table 4 gives an indication of how well the model duplicated measured historical water-level data. The smaller the average difference between the model generated potentiometric heads and the measured water levels, the better the model is simulating the aquifer system. However, because of the very sporadic areal distribution of the data, the degree to which the model duplicates historical water levels can only be assessed where sufficient water-level data exist.

There is some inherent error in the model results and in the measured water levels that may be reflected in the table. Most of the water-level measurements were made in withdrawal wells. These water levels could reflect effects of recent pumping from the measured well. Also, nearby pumping can result in nonrepresentative water levels. Errors in identifying the layer(s) in which a well was completed, vertical differences of the water level within an individual aquifer, and inaccurate measurements of water levels in the wells can result in additional errors. Errors in the model formulation, estimation of the hydrologic parameters, and the lateral differences between well location and node center in the model will also produce differences between the computed potentiometric heads and the measured water levels. The table does reflect the best composite set of average arithmetic and absolute differences obtained between the computed potentiometric heads and the measured water levels for the steady-state model, and the 1914, 1957, and 1981 transient calibration periods for the transient model. 
Table 3. Estimated ground-water pumpage, northeastern Wisconsin, 1895-1981

(All pumpage is in millions of gallons per year)

\begin{tabular}{|c|c|c|c|c|c|c|c|c|c|c|c|}
\hline \multirow[b]{2}{*}{ County } & \multirow[b]{2}{*}{$\begin{array}{c}\text { Source } \\
\text { aquifers' }\end{array}$} & \multicolumn{10}{|c|}{ YEARS } \\
\hline & & $\begin{array}{l}1895- \\
1904\end{array}$ & $\begin{array}{c}1905- \\
1914\end{array}$ & $\begin{array}{l}1915- \\
1924\end{array}$ & $\begin{array}{l}1925- \\
1934\end{array}$ & $\begin{array}{c}1935- \\
1944\end{array}$ & $\begin{array}{l}1945- \\
1954\end{array}$ & $\begin{array}{c}1955- \\
1957\end{array}$ & $\begin{array}{c}1958- \\
1964\end{array}$ & $\begin{array}{l}1965- \\
1974\end{array}$ & $\begin{array}{c}1975- \\
1981\end{array}$ \\
\hline Brown & $\begin{array}{r}1 \\
2 \\
1.2 \\
1,2,3 \\
2,3 \\
3\end{array}$ & $\begin{array}{l}--- \\
-\cdots \\
560.4 \\
-- \\
-- \\
--\end{array}$ & $\begin{array}{l}--- \\
--- \\
560.4 \\
-- \\
--- \\
---\end{array}$ & $\begin{array}{l}-\cdots \\
560.4 \\
-- \\
-\cdots \\
--\end{array}$ & $\begin{array}{c}\ldots . \\
1.548 .6 \\
\cdots \\
\cdots \\
\cdots-\end{array}$ & $\begin{array}{l}--- \\
1,548.6 \\
-- \\
-- \\
--\end{array}$ & $\begin{array}{c}--- \\
11.7 \\
3.778 .4 \\
-\cdots \\
\cdots \\
---\end{array}$ & $\begin{array}{r}92.3 \\
11.3 \\
3,658.5 \\
--- \\
--- \\
---\end{array}$ & $\begin{array}{c}66.8 \\
11.7 \\
1.919 .8 \\
-\cdots \\
--- \\
---\end{array}$ & $\begin{array}{r}41.6 \\
17.9 \\
1.963 .9 \\
--- \\
--- \\
--\end{array}$ & $\begin{array}{r}176.3 \\
16.8 \\
2,347.3 \\
--- \\
--- \\
---\end{array}$ \\
\hline Subtotal & & $\overline{560.4}$ & $\overline{560.4}$ & $\overline{560.4}$ & $\overline{1,546.6}$ & $\overline{1,548.6}$ & $\overline{3,790.1}$ & $\overline{3,782.1}$ & $\overline{1,998.3}$ & $\overline{2.023 .4}$ & $\overline{2,540.4}$ \\
\hline Calumet & $\begin{array}{r}1 \\
2 \\
1,2 \\
1,2,3 \\
2.3 \\
3\end{array}$ & $\begin{array}{l}--- \\
--- \\
--- \\
--- \\
---\end{array}$ & $\begin{array}{l}--- \\
-- \\
--- \\
--- \\
---\end{array}$ & $\begin{array}{l}--- \\
--- \\
-- \\
--- \\
-- \\
49.7\end{array}$ & $\begin{array}{r}-. \\
-0.0 \\
.8 \\
127.0\end{array}$ & $\begin{array}{r}-- \\
-- \\
6.4 \\
-1.7 \\
160.8\end{array}$ & $\begin{array}{c}8.0 \\
1.7 \\
337.8\end{array}$ & $\begin{array}{l}--- \\
--- \\
--- \\
-- \\
1.7 \\
452.9\end{array}$ & $\begin{array}{r}--- \\
--- \\
-- \\
-1.7 \\
486.0\end{array}$ & $\begin{array}{r}--- \\
--- \\
--- \\
-\overline{9.4} \\
610.2\end{array}$ & $\begin{array}{c}--- \\
--- \\
--- \\
-12.7 \\
890.8\end{array}$ \\
\hline Subtotal & & & & $\overline{49.7}$ & $\overline{133.8}$ & $\overline{168.9}$ & $\overline{347.5}$ & $7 \overline{854.6}$ & $\overline{487.7}$ & $\overline{619.6}$ & $\overline{903.5}$ \\
\hline Door & $\begin{array}{r}1 \\
2 \\
1,2 \\
1,2,3 \\
2,3 \\
3\end{array}$ & $\begin{array}{l}--- \\
-- \\
--- \\
-- \\
---\end{array}$ & $\begin{array}{l}--- \\
\cdots- \\
-- \\
16.3 \\
--\end{array}$ & $\begin{array}{l}--- \\
--- \\
--- \\
--- \\
54.4 \\
---\end{array}$ & $\begin{array}{c}-\cdots \\
\cdots- \\
--- \\
-59.5 \\
1.1\end{array}$ & $\begin{array}{l}--. \\
--- \\
-- \\
-78.5 \\
123.9\end{array}$ & $\begin{array}{c}\ldots- \\
\cdots- \\
\cdots- \\
74.3 \\
329.7\end{array}$ & $\begin{array}{c}--- \\
-\ldots \\
--- \\
-\cdots \\
88.6 \\
389.2\end{array}$ & $\begin{array}{c}--- \\
-\cdots \\
--- \\
-\cdots \\
80.6 \\
458.4\end{array}$ & $\begin{array}{c}--- \\
-- \\
-- \\
-\cdots \\
74.5 \\
528.9\end{array}$ & $\begin{array}{r}--. \\
-- \\
--- \\
-- \\
7.7 \\
774.7\end{array}$ \\
\hline Subtotal & & & $\overline{16.3}$ & 54.4 & $\overline{60.6}$ & $\overline{202.4}$ & $\overline{404.0}$ & $\overline{487.6}$ & $\overline{539.0}$ & $\overline{603.4}$ & $\overline{782.4}$ \\
\hline Fond du Lac & $\begin{array}{r}1 \\
2 \\
1.2 \\
1.2 .3 \\
2,3 \\
3\end{array}$ & $\begin{array}{l}--- \\
-\cdots \\
390.0 \\
22.3 \\
--\end{array}$ & $\begin{array}{r}4.2 \\
413.5 \\
-- \\
29.2 \\
--\end{array}$ & $\begin{array}{r}9.6 \\
445.8 \\
-- \\
62.7 \\
---\end{array}$ & $\begin{array}{r}--- \\
72.2 \\
50.8 .8 \\
108.1 \\
3.9\end{array}$ & $\begin{array}{r}-136.3 \\
810.9 \\
210.0 \\
4.1\end{array}$ & $\begin{array}{r}396.4 \\
307.4 \\
886.3 \\
23.8 \\
182.6 \\
4.8\end{array}$ & $\begin{array}{r}612.3 \\
330.3 \\
789.0 \\
40.6 \\
174.8 \\
5.0\end{array}$ & $\begin{array}{r}653.2 \\
484.9 \\
842.5 \\
60.6 \\
186.3 \\
5.1\end{array}$ & $\begin{array}{r}994.9 \\
492.7 \\
721.9 \\
80.5 \\
220.8 \\
7.2\end{array}$ & $\begin{array}{r}1,236.7 \\
569.1 \\
583.3 \\
121.8 \\
262.7 \\
7.3\end{array}$ \\
\hline Subtotal & & $\overline{412.3}$ & $\overline{448.9}$ & $\overline{518.1}$ & $\overline{693.0}$ & $\overline{1,161.3}$ & $\overline{1.801 .3}$ & 1,952 & $\overline{2.234 .6}$ & $\overline{2.518 .0}$ & $\overline{2,780.9}$ \\
\hline Green Lake & $\begin{array}{r}1 \\
2 \\
1.2 \\
1,2.3 \\
2.3 \\
3\end{array}$ & $\begin{array}{l}54.4 \\
--- \\
-- \\
--- \\
--- \\
---\end{array}$ & $\begin{array}{l}62.4 \\
-- \\
--- \\
--- \\
--- \\
--\end{array}$ & $\begin{array}{l}103.1 \\
-- \\
-- \\
-- \\
-- \\
--\end{array}$ & $\begin{array}{l}119.7 \\
--- \\
-- \\
-- \\
--- \\
--\end{array}$ & $\begin{array}{l}190.8 \\
-- \\
-- \\
-- \\
-\cdots \\
--\end{array}$ & $\begin{array}{l}408.0 \\
-- \\
-\cdots \\
-\cdots \\
-- \\
--\end{array}$ & $\begin{array}{c}463.1 \\
-38.9 \\
-\cdots \\
--- \\
--\end{array}$ & $\begin{array}{c}521.9 \\
-5 \\
51.5 \\
-- \\
-- \\
--\end{array}$ & $\begin{array}{c}634.8 \\
-4 \\
40.5 \\
-- \\
-- \\
--\end{array}$ & $\begin{array}{r}878.1 \\
24.3 \\
61.3 \\
--- \\
--- \\
---\end{array}$ \\
\hline Subtotal & & $\overline{54.4}$ & $\overline{62.4}$ & $\overline{103.1}$ & $\overline{119.7}$ & $\overline{190.8}$ & $\overline{408.0}$ & $\overline{522.0}$ & $\overline{573.4}$ & $\overline{675.3}$ & $\overline{963.7}$ \\
\hline Kewaunee & $\begin{array}{r}1 \\
2 \\
1,2 \\
1,2,3 \\
2,3 \\
3\end{array}$ & $\begin{array}{c}--- \\
--- \\
--- \\
-- \\
---\end{array}$ & $\begin{array}{c}--- \\
--- \\
--- \\
-\cdots \\
21.4 \\
--\end{array}$ & $\begin{array}{l}--- \\
--- \\
-- \\
19.7 \\
82.1\end{array}$ & $\begin{array}{c}--- \\
--- \\
--- \\
--- \\
25.2 \\
132.1\end{array}$ & $\begin{array}{l}--- \\
-- \\
--- \\
--- \\
50.8 \\
74.7\end{array}$ & $\begin{array}{l}--- \\
-\ldots \\
-- \\
-- \\
62.7 \\
98.7\end{array}$ & $\begin{array}{c}--- \\
--- \\
--- \\
-- \\
97.8 \\
106.2\end{array}$ & $\begin{array}{r}--- \\
--- \\
--- \\
-\cdots \\
97.5 \\
132.7\end{array}$ & $\begin{array}{r}-\ldots \\
-\ldots \\
-\cdots \\
-- \\
85.6 \\
187.3\end{array}$ & $\begin{array}{l}--- \\
-- \\
-- \\
46.1 \\
290.0\end{array}$ \\
\hline Subtotal & & & $\overline{21.4}$ & $\overline{101.8}$ & $\overline{157.3}$ & $\overline{125.5}$ & $\overline{179.4}$ & 204.0 & 230.2 & $\overline{272.9}$ & 336.1 \\
\hline Manitowoc & $\begin{array}{r}1 \\
2 \\
1,2 \\
1,2,3 \\
2,3 \\
3\end{array}$ & $\begin{array}{l}--- \\
--- \\
--- \\
-- \\
--- \\
32.0\end{array}$ & $\begin{array}{l}--- \\
--- \\
--- \\
--- \\
--- \\
137.9\end{array}$ & $\begin{array}{l}--- \\
--- \\
--- \\
--- \\
--- \\
202.4\end{array}$ & $\begin{array}{l}--- \\
-- \\
-- \\
-\overline{-} \\
\overline{310.5}\end{array}$ & $\begin{array}{l}--- \\
--- \\
-- \\
-- \\
-- \\
154.9\end{array}$ & $\begin{array}{c}--- \\
--- \\
-- \\
-\overline{-} \\
212.3\end{array}$ & $\begin{array}{l}--- \\
--- \\
--- \\
-- \\
-- \\
248.8\end{array}$ & $\begin{array}{l}--- \\
--- \\
--- \\
--- \\
--- \\
313.9\end{array}$ & $\begin{array}{l}-- \\
-- \\
-- \\
-- \\
-- \\
414.6\end{array}$ & $\begin{array}{l}-- \\
--- \\
--- \\
-- \\
551.3\end{array}$ \\
\hline Subtotal & & $\overline{32.0}$ & $\overline{137.9}$ & $\overline{202.4}$ & $\overline{310.5}$ & $\overline{154.9}$ & 212.3 & $\overline{248.8}$ & $\overline{313.9}$ & 414.6 & $\overline{551.3}$ \\
\hline Marinette & $\begin{array}{r}1 \\
2 \\
1,2 \\
1.2 .3 \\
2.3 \\
3\end{array}$ & $\begin{array}{c}-- \\
-- \\
5.0 \\
-- \\
--\end{array}$ & $\begin{array}{c}--- \\
-- \\
5.0 \\
--- \\
---\end{array}$ & $\begin{array}{c}-- \\
19.8 \\
\cdots \\
\cdots- \\
\cdots\end{array}$ & $\begin{array}{c}-- \\
27.0 \\
3.5 \\
--- \\
-\cdots\end{array}$ & $\begin{array}{c}-- \\
50.2 \\
17.2 \\
--- \\
--- \\
---\end{array}$ & $\begin{array}{c}24.3 \\
39.5 \\
61.5 \\
--- \\
--- \\
---\end{array}$ & $\begin{array}{l}37.4 \\
31.1 \\
77.6 \\
--- \\
--- \\
---\end{array}$ & $\begin{array}{c}--- \\
28.5 \\
84.6 \\
--- \\
--- \\
---\end{array}$ & $\begin{array}{l}64.6 \\
17.6 \\
94.1 \\
--- \\
--- \\
---\end{array}$ & $\begin{array}{c}96.6 \\
-196.2 \\
--- \\
--- \\
--\end{array}$ \\
\hline Subtotal & & 5.0 & 5.0 & $\overline{19.8}$ & $\overline{30.5}$ & $\overline{67.4}$ & $\overline{125.3}$ & $\overline{146.3}$ & $\overline{113.1}$ & $\overline{176.3}$ & $\overline{292.8}$ \\
\hline
\end{tabular}


Table 3. Estimated ground-water pumpage, northeastern Wisconsin, 1895-1981-Continued

(All pumpage is in millions of gallons per year)

\begin{tabular}{|c|c|c|c|c|c|c|c|c|c|c|c|}
\hline \multirow[b]{2}{*}{ County } & \multirow[b]{2}{*}{$\begin{array}{c}\text { Source } \\
\text { aquifers }^{3}\end{array}$} & \multicolumn{10}{|c|}{ YEARS } \\
\hline & & $\begin{array}{l}1895- \\
1904\end{array}$ & $\begin{array}{l}1905- \\
1914\end{array}$ & $\begin{array}{l}1915- \\
1924\end{array}$ & $\begin{array}{c}1925- \\
1934\end{array}$ & $\begin{array}{l}1935- \\
1944\end{array}$ & $\begin{array}{l}1945- \\
1954\end{array}$ & $\begin{array}{l}1955- \\
1957\end{array}$ & $\begin{array}{l}1958- \\
1964\end{array}$ & $\begin{array}{l}1965- \\
1974\end{array}$ & $\begin{array}{l}1975- \\
1981\end{array}$ \\
\hline \multirow[t]{5}{*}{ Oconto } & 1 & -- & -- & --- & $-\cdots$ & --- & --- & --- & 22.4 & 38.6 & 53.4 \\
\hline & 2 & --- & --- & 15.4 & -- & -- & -- & -- & -- & -- & 6.8 \\
\hline & 1.2 & 160.0 & 162.3 & 151.8 & 154.4 & 138.7 & 165.3 & 174.5 & 183.1 & 209.4 & 421.7 \\
\hline & $\begin{array}{r}1,2,3 \\
2,3\end{array}$ & --- & $\cdots$ & & $\cdots$ & -- & -- & -- & -- & -- & -- \\
\hline & 3 & - & -- & - & $\ldots$ & - & $\ldots$ & $\ldots$ & - & - & $\cdots$ \\
\hline Subtotal & & $\overline{180.0}$ & $\overline{163.3}$ & $\overline{167.2}$ & $\overline{184.4}$ & $\overline{138.7}$ & $\overline{165.3}$ & $\overline{174.5}$ & $\overline{205.5}$ & $\overline{248.0}$ & $\overline{418.9}$ \\
\hline \multirow[t]{6}{*}{ Outagamie } & 1 & 360.5 & 400.9 & 46.6 & 69.3 & 114.8 & 137.4 & 151.9 & 168.3 & 191.4 & 279.0 \\
\hline & 2 & 1.8 & 2.8 & -- & 57.0 & 58.6 & 180.1 & 235.6 & 293.0 & 308.0 & 314.6 \\
\hline & 1.2 & --- & -- & 99.1 & 138.8 & 334.9 & 450.1 & 584.1 & 668.9 & 798.8 & 834.2 \\
\hline & $1,2,3$ & $\cdots$ & $\cdots$ & -- & -- & --- & --- & -- & -- & -- & 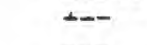 \\
\hline & $\begin{array}{r}2.3 \\
3\end{array}$ & $\cdots$ & -- & -- & -- & $\cdots$ & -- & -- & -- & -- & $\cdots$ \\
\hline & & $\cdots$ & $\cdots$ & $\cdots$ & $\cdots$ & $\cdots$ & $-\cdots$ & -- & $\cdots$ & $\cdots$ & -+ \\
\hline Subtotal & & $\overline{362.3}$ & $\overline{403.7}$ & $\overline{145.7}$ & $\overline{285.1}$ & $\overline{508.3}$ & $\overline{787.6}$ & $\overline{971.6}$ & $\overline{1.130 .2}$ & $\overline{1.295 .2}$ & $\overline{1.427 .8}$ \\
\hline \multirow[t]{5}{*}{ Sheboygan } & 1 & -- & --- &.-- & -- & --- & -- & -- & --- & --- & -- \\
\hline & 2 & -- & -- & -- & -- & -- & $\cdots$ & -- & -- & -- & $m$ \\
\hline & 1.2 & --- & --- & 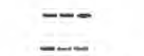 & -- & -- & $-\cdots$ & -- & -- & -- & -- \\
\hline & $\begin{array}{r}1.2 .3 \\
2.3\end{array}$ & -- & -- & 3.8 & 5.2 & 5.6 & 6.1 & 6. 3 & 6.5 & 6.8 & 7.2 \\
\hline & 3 & 9.0 & 41.7 & 187.1 & 290.8 & 644.9 & 1.093 .0 & 1.164 .0 & 1.297 .1 & 1.636 .9 & 1.734 .1 \\
\hline Subtotal & & 9.0 & 41.7 & 190.8 & 296.0 & 650.5 & $1,099.1$ & 1.170 .3 & 1.303 .6 & 1.643 .7 & $1,741.3$ \\
\hline \multirow[t]{5}{*}{ Shawano } & 1 & -- & -- & -- & -- & 15.1 & 152.8 & 213.4 & 221.3 & 273.8 & 541.4 \\
\hline & 2 & -- & -- & -- & -- & $\cdots$ & $\rightarrow$ & --- & -- & 4.0 & -- \\
\hline & 1,2 & $\cdots$ & $\rightarrow$ & -- & $\cdots$ & -- & -- & $\cdots$ & -- & -- & -- \\
\hline & $\begin{array}{r}1,2,3 \\
2,3\end{array}$ & --- & -- & --- & $\cdots$ & -- & $\cdots$ & -- & $\cdots$ & -- & --- \\
\hline & 3 & -- & -- & 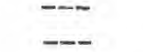 & 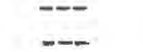 & 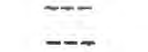 & -- & -- & -- & -- & $\cdots$ \\
\hline Subtotal & & & & & & $\overline{15.1}$ & & $\overline{0.0}$ & $\overline{0919}$ & $\bar{\square}$ & $\overline{=}$ \\
\hline & & & & & & & & & & & \\
\hline \multirow[t]{6}{*}{ Winnebago } & 1 & -- & --- & 10.4 & 10.8 & 21.9 & 138.9 & 169.3 & 175.3 & 168.9 & 166.7 \\
\hline & 2 & -- & --- & 29.6 & 181.2 & 744.5 & $1,017.2$ & 787.7 & 806.8 & 861.8 & 970.4 \\
\hline & 1.2 & 898.8 & 215.1 & 388.7 & 419.0 & 823.7 & 1.242 .0 & 1.824 .2 & $1,965.7$ & 2.158 .2 & $2,674.5$ \\
\hline & $1.2,3$ & --- & --- & -- & -- & -- & , --- & --- & -- & -- & -- \\
\hline & 2,3 & -- & $\cdots$ & -- & -- & -- & $\cdots$ & $\cdots$ & $-\cdots$ & $\cdots$ & -- \\
\hline & 3 & -- & $\cdots$ & $\cdots$ & -- & --- & -- & -- & -- & --- & $\cdots$ \\
\hline Subtotal & & $\overline{898.8}$ & $\overline{215.1}$ & $\overline{428.7}$ & $\overline{611}$ & $\overline{1.590 .1}$ & $\overline{2.398 .1}$ & $\overline{2.781 .2}$ & $\overline{2.947 .8}$ & $\overline{3.186 .8}$ & $\overline{3.811 .6}$ \\
\hline \multirow[t]{5}{*}{ Waupaca } & 1 & --- & --- & -- & $\ldots$ & -- & -- & 3.5 & 3.5 & 3.5 & 3.0 \\
\hline & 2 & -- & -- & $\cdots$ & -- & -- & -- & -- & -- & -- & -- \\
\hline & $\begin{array}{r}1,2 \\
1.3\end{array}$ & -- & --- & -- & $\ldots$ & -- & -- & --- & -- & -- & -- \\
\hline & 2,3 & $\ldots$ & $\ldots$ & $\ldots$ & --- & $\ldots$ & - & - & $\ldots$ & - & $\cdots$ \\
\hline & 3 & --- & --- & -- & -- & --- & $\cdots$ & --- & $\cdots$ & $\rightarrow$ & -- \\
\hline Subtotal & & & & & & & & $\overline{3.5}$ & $\overline{3.5}$ & $\overline{3.5}$ & $\overline{3.0}$ \\
\hline \multirow[t]{5}{*}{ Waushara } & 1 & -- & -- & -- & --- & --- & --- & 7.9 & 15.6 & 46.1 & 45.9 \\
\hline & 2 & --- & -- & $\cdots$ & -- & -- & -- & -- & $\cdots$ & -- & -- \\
\hline & $\begin{array}{r}1,2 \\
1,2.3\end{array}$ &.- & -- & $\cdots$ & - & - & $\ldots$ & -- & --- & - & $=-$ \\
\hline & 2.3 & --- & $\ldots$ & $\ldots$ & -- & -- & $\ldots$ & --- & --- & - & --- \\
\hline & 3 & $\cdots$ & -- & --- & --- & -- & $\cdots$ & - & -- & -- & --- \\
\hline Subtotal & & & & & & & & $\overline{7.9}$ & $\overline{15.6}$ & $\overline{46.1}$ & $\overline{45.9}$ \\
\hline TOTAL & & 2.494 .2 & $2,074.1$ & $2,542.2$ & 4.380 .5 & 6.522 .5 & 11.850 .8 & 13.100 & $12,317.7$ & $14,004.7$ & 17,204 \\
\hline
\end{tabular}

See Table 1. 
Table 4. Comparison between model-computed potentiometric heads and measured water levels

\begin{tabular}{|c|c|c|c|c|c|c|c|c|c|}
\hline \multirow[b]{2}{*}{$\begin{array}{c}\text { Model } \\
\text { simulation }\end{array}$} & \multicolumn{3}{|c|}{ Aquifer 1} & \multicolumn{3}{|c|}{ Aquifer 2} & \multicolumn{3}{|c|}{ Composite aquifers 1 and 2} \\
\hline & $\begin{array}{c}\text { Average } \\
\text { aritmetic } \\
\text { difference } \\
\text { between the } \\
\text { computed and } \\
\text { measured } \\
\text { water levels' } \\
\text { (feet) }\end{array}$ & $\begin{array}{c}\text { Average } \\
\text { absolute } \\
\text { difference } \\
\text { between the } \\
\text { computed and } \\
\text { measured } \\
\text { water level } \\
\text { (feet) }\end{array}$ & $\begin{array}{c}\text { Number of } \\
\text { measured } \\
\text { water } \\
\text { levels }\end{array}$ & $\begin{array}{l}\text { Average } \\
\text { arithmetic } \\
\text { difference } \\
\text { between the } \\
\text { computed and } \\
\text { measured } \\
\text { water levels' } \\
\text { (feet) }\end{array}$ & $\begin{array}{c}\text { Average } \\
\text { absolute } \\
\text { difference } \\
\text { between the } \\
\text { computed and } \\
\text { measured } \\
\text { water levels }{ }^{2} \\
\text { (feet) }\end{array}$ & $\begin{array}{c}\text { Number of } \\
\text { measured } \\
\text { water } \\
\text { levels }\end{array}$ & $\begin{array}{c}\text { Average } \\
\text { arithmetic } \\
\text { difference } \\
\text { between the } \\
\text { computed and } \\
\text { measured } \\
\text { water levels } \\
\text { (feet) }\end{array}$ & $\begin{array}{c}\text { Average } \\
\text { absolute } \\
\text { difference } \\
\text { between the } \\
\text { computed and } \\
\text { measured } \\
\text { water levels } 2 \\
\text { (feet) }\end{array}$ & $\begin{array}{c}\text { Number of } \\
\text { measured } \\
\text { water } \\
\text { levels }\end{array}$ \\
\hline $\begin{array}{l}\text { Steady-state } \\
\text { model }\end{array}$ & 3.4 & 43.7 & 13 & 15.7 & 32.0 & 13 & $\cdots$ & -- & $\cdots$ \\
\hline \multicolumn{10}{|c|}{ Transient model } \\
\hline $\begin{array}{l}1914 \\
\text { calibration } \\
\text { period }\end{array}$ & -- & -- & -- & $\cdots$ & $-\cdots$ & -- & -8.9 & 37.2 & 13 \\
\hline $\begin{array}{l}1957 \\
\text { calibration } \\
\text { period }\end{array}$ & -65.0 & 65.0 & 1 & -39.8 & 49.7 & 44 & -2.1 & 55.7 & 39 \\
\hline $\begin{array}{l}1961 \\
\text { calibration } \\
\text { period }\end{array}$ & -21.5 & 70.0 & 11 & -5.2 & 34.4 & 130 & 1.0 & 33.7 & 49 \\
\hline
\end{tabular}

Derived by adding when computer-simulated value was higher than measured value (positive number) and subtracting when computer-simulated value was lower than measured value (negative number).

2 The absolute value of a number is the number without its associated sign. For example, the absolute value of 4 and -4 are the same.

\section{Steady-State Model}

Calibration

The model, run without inputting pumpage and storage coefficient values for the aquifers, is referred to as the steadystate model. The steady-state or nonpumping model provides information on the hydrologic conditions in the aquifer system prior to pumping.

Potentiometric head relationships and flow between the aquifers are the least understood aspect of the aquifer system. Except for two packer tests (table 2) and a few driller's reports of water-level changes in wells during construction, no quantitative vertical potentiometric-head information is known about the aquifer system. The model provides the only means of making head comparisons among the aquifers over a large area.

There are no potentiometric-head data available for aquifers 1 and 2 for the period prior to ground-water development which began in about 1886 . The data points shown in figures 12 and 13 are locations of water-level measurements reported by Wiedman and Schultz (1915). These measurements were made prior to 1915 but probably do not represent the prepumping composite potentiometric surface. The water-level data were used, however, to check the reasonableness of the prepumping steady-state potentiometric surfaces of aquifers 1 and 2 . These measurements were also used to calculate the steady-state model differences in table 4. The table indicates that the average arithmetic difference between the computed potentiometric heads and the measured water levels was $3.4 \mathrm{ft}$ and the average absolute difference was $437 \mathrm{ft}$. The prepumping steady-state potentiometric-head maps of aquifers 1 and 2 (figs. 12 and 13) were computed as part of the calibration process. Aquifers 3 and 4 have similar potentiometric heads which probably have not changed appreciably from prepumping to present (1981). Therefore, the water-table surface in 1981, shown in figure 11 , also adequately represents the predevelopment steadystate potentiometric surfaces of aquifers 3 and 4. Comparing the steady-state aquifer 3 potentiometric head with those in aquifer 4 indicates that the aquifer 3 heads are generally equal to those in aquifer 4. Due to the simplifying assumptions in the model, the size of the model area, and the state of the knowledge of the geohydrology, the computed steady-state heads for all aquifers will contain inaccuracies. However, the steady-state model provides the best means of approximating these heads in aquifers 1 and 2 prior to pumping.

\section{Discussion}

Prior to ground-water withdrawals, the potentiometric surface of aquifer 1 ranged from greater than $900 \mathrm{ft}$ above sea level in the northwestern part of the study area to less than $700 \mathrm{ft}$ in the northeast (fig. 12). The highest potentiometric heads occur in the west where aquifers 2 and 3 and confining beds 2 and 3 are missing. Ground-water flow in aquifer 1 generally is to the northeast.

The potentiometric heads in aquifer 2 (fig. 13) range from greater than $900 \mathrm{ft}$ above sea level in the northwestern and southwestern corners of the study area to less than 650 $\mathrm{ft}$ in the northeastern part of the area. The flow in aquifer 2 generally is to the northeast.

Pumpage from aquifer 3 has generally been from lowcapacity wells spread over the aquifer, and has not been sufficient to produce significant drawdowns. As a result, the predevelopment steady-state potentiometric surface is nearly identical with the present surface. The potentiometric heads in aquifer 3 reflect the topography and are very similar to 


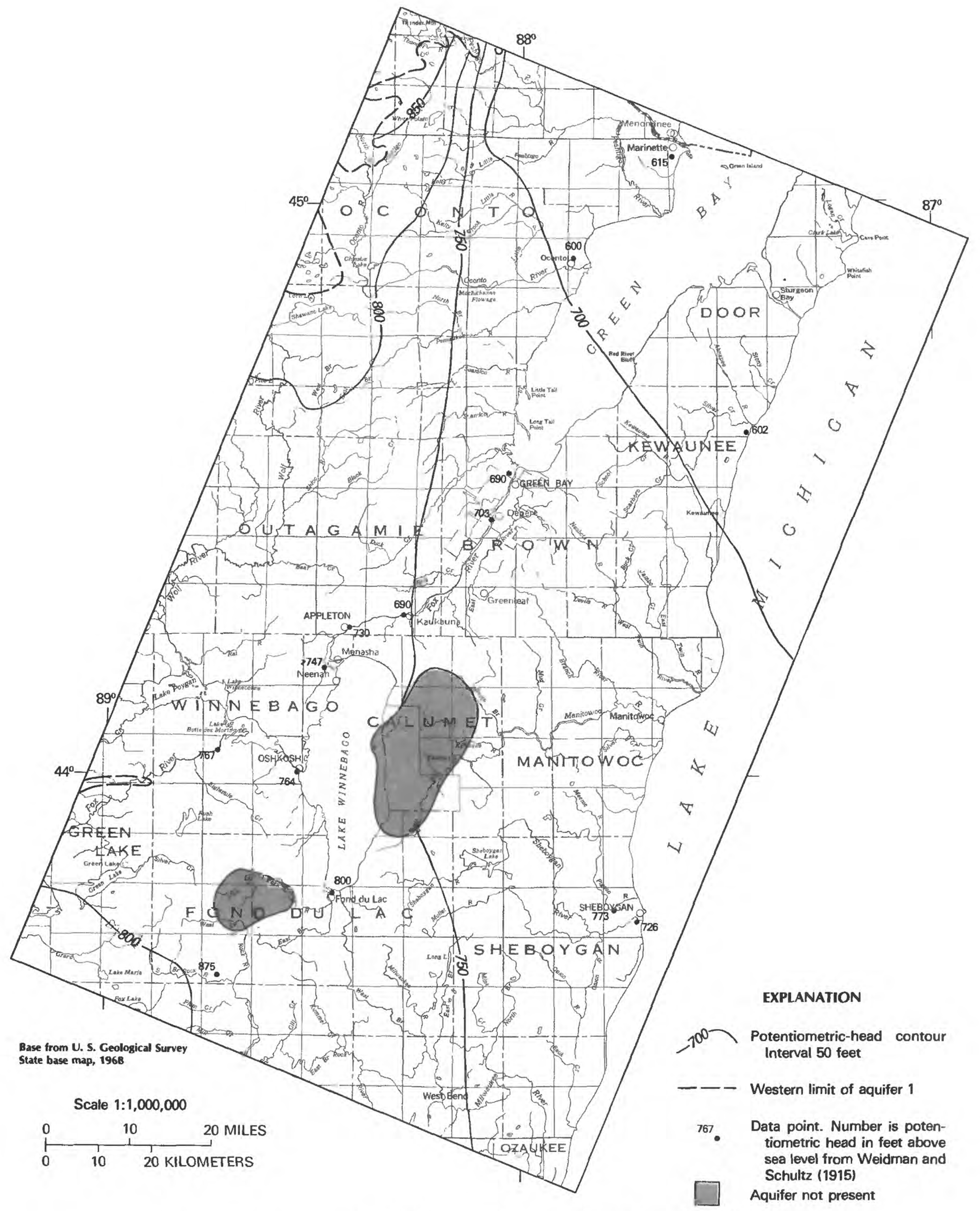

Figure 12. Computer-simulated prepumping potentiometric surface of aquifer 1 . 


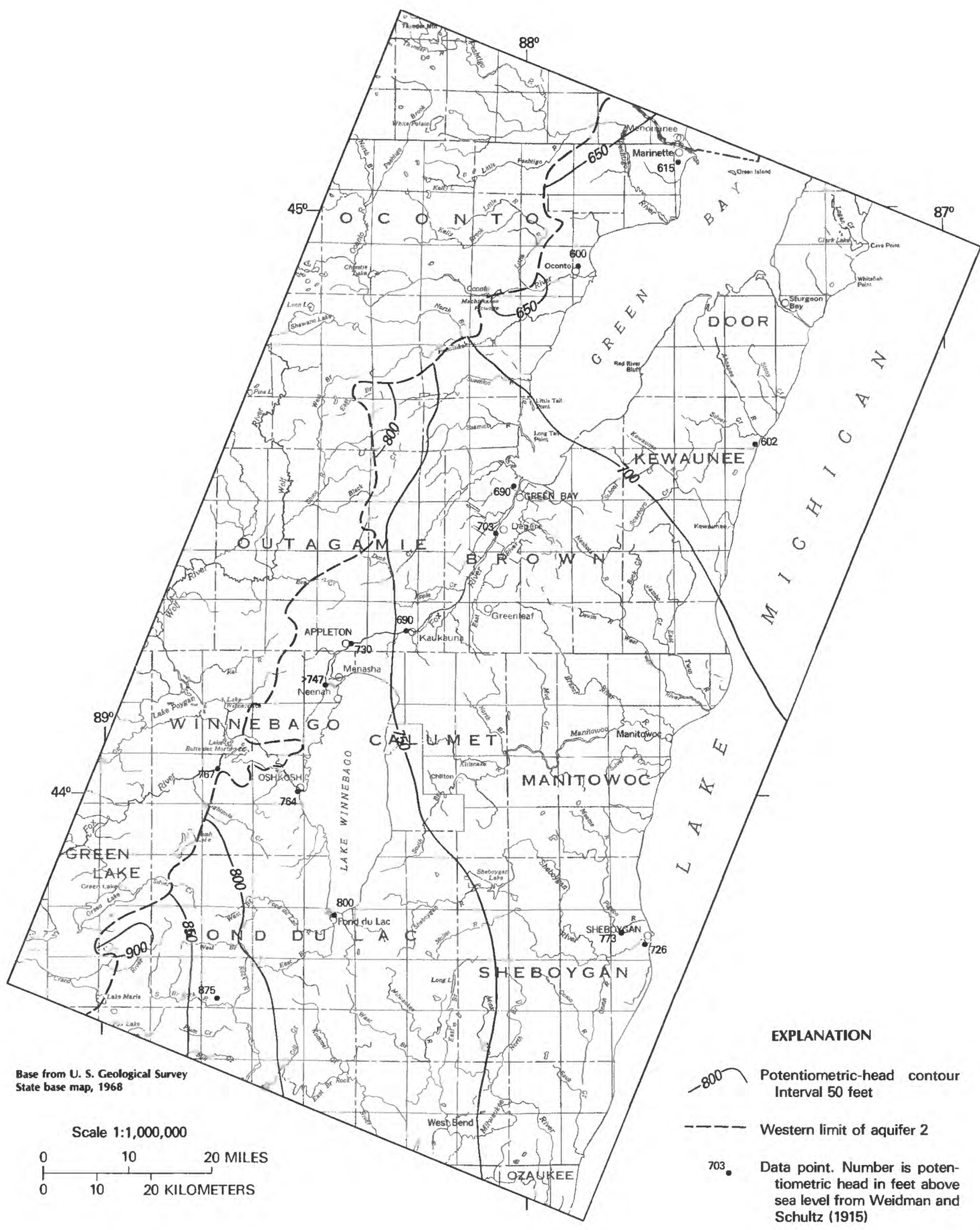

Figure 13. Computer-simulated prepumping potentiometric surface of aquifer 2 . 


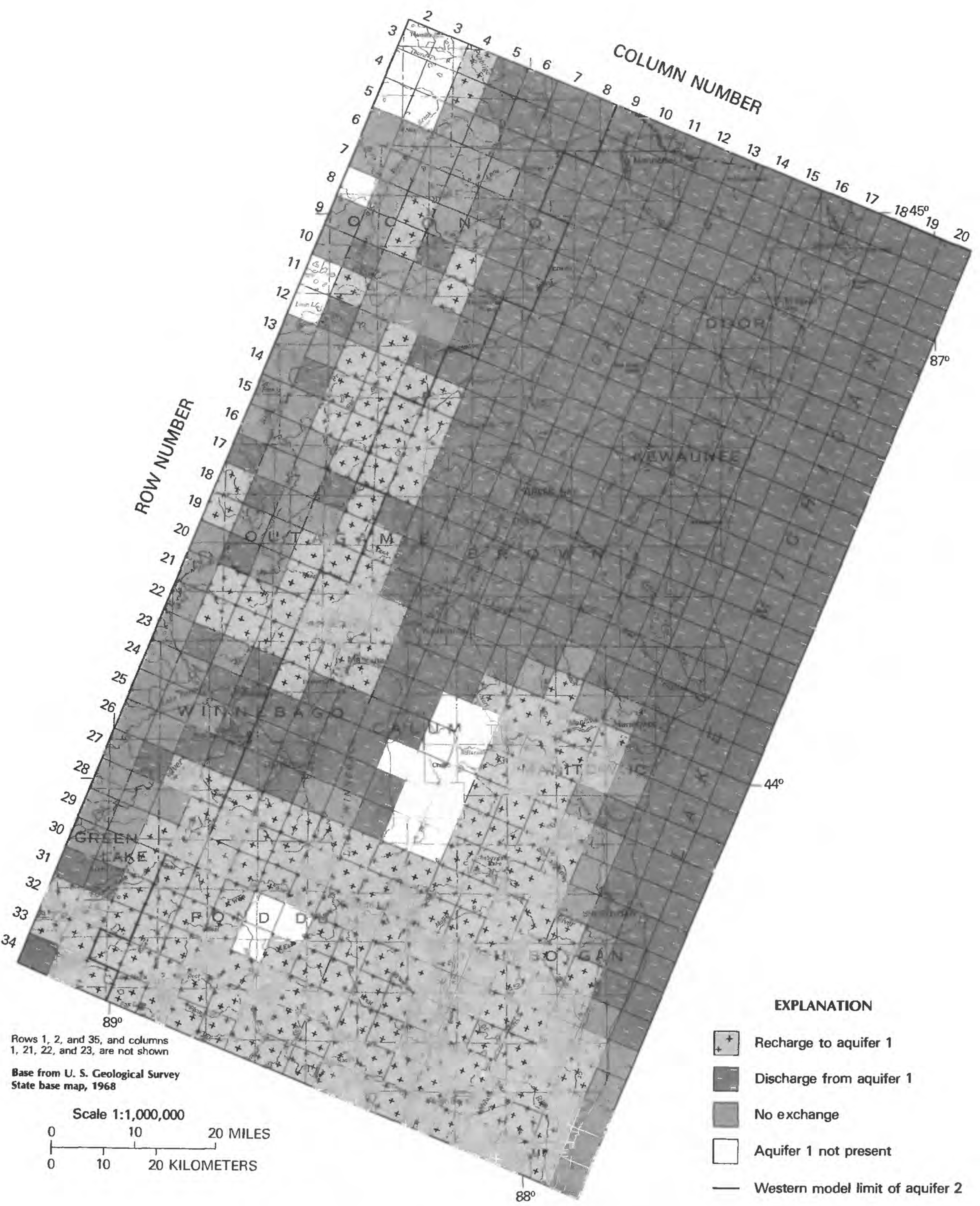

Figure 14. Prepumping vertical water movement between aquifer 1 and overlying aquifer. 
the heads in aquifer 4 (fig. 11). The potentiometric heads in aquifer 3 range from greater than $1,000 \mathrm{ft}$ above sea level, southeast of Lake Winnebago, to $580 \mathrm{ft}$, the altitude of Green Bay and Lake Michigan.

Aquifer 4 is modeled as a specified head and is, therefore, not an active layer. The aquifer is a boundary and functions as a source or sink for the underlying aquifers.

The nodal data used to plot the above-mentioned aquiferhead maps were compared to determine vertical flow between aquifers. The prepumping steady-state vertical water movement between aquifers 1 and 2 are shown in figure 14 . Recharge to aquifer 1 occurs when the head in aquifer 2 is greater than the head in aquifer 1 and discharge from aquifer 1 occurs when the head in aquifer 2 is less than the head in aquifer 1. The model indicates that prior to pumping, recharge to aquifer 1 occurred in the southern part of the study area and along the western edge. Discharge occurred in the northeastern part of the study area. Along the very western edge and the southeastern corner of the study area, the potentiometric head of aquifers 1 and 2 were equal. Just east of Lake Winnebago and west of the city of Fond du Lac are areas where aquifer 1 is not present due to topographic highs in the underlying Precambrian crystalline rock.

The qualitative steady-state potentiometric-head relationships between aquifers 2 and 3 are shown in figure 15 . Recharge to aquifer 2 occurred in the southern part of the study area and extends northward into the Door County Peninsula. Discharge from aquifer 2 to aquifer 3 occurred in the lower Fox River Valley, Green Bay and Lake Michigan. Along the western side of the study area, many of the nodal potentiometric head values in aquifers 2 and 3 were equal, indicating no exchange between the aquifers is occurring.

\section{Transient Model}

The transient model is essentially the same as the steadystate model, except that pumpage from and storage in the aquifers are considered. The transient or pumping model simulated 10 consecutive pumping periods between 1895 and 1981 (table 3). The starting potentiometric heads for aquifers 1,2 , and 3 in the transient model are the computed heads generated by the steady-state model. Much of the available historical potentiometric-head data for aquifers 1 and 2 are from wells open to both of these aquifers. To allow for comparisons between observed and computed heads in the aquifer system, the model program was modified by the northern Midwest RASA group to include a multiaquifer function (Bennett, Kontis, and Larson, 1982) to compute the composite heads for aquifers 1 and 2 . The modification allows the model to compute the composite head for each node specified, based on the transmissivity, pumpage, and computed head of each aquifer at the end of the pumping period.

The following sections compare model output with known hydrology at the end of 3 periods of the 10 pumping period simulations. The three periods (1895-1914, 1895-1957, and 1895-1981) were selected for calibration because of the large amount of published and other available data for those periods of time. However, upon analyzing the historical data, much of the well-construction and geologiclog data were determined to be either inadequate or inaccurate and there was a poor distribution of wells penetrating aquifers 1 and 2 . As a result, the traditional comparison of the potentiometric surfaces contoured from the output of the model simulation with those compiled from the measured water-level data could not be done. Acceptance of a model produced potentiometric surface map was made when the contours on the map adequately represented visually the corresponding observed point data or clusters of point data. Calibration of the model was achieved when all of the model produced maps for each of the calibration periods were within acceptable limits. Table 4 gives an indication of the ability of the model to duplicate measured historical water-level data and reflects the best composite set of average arithmetic and absolute differences between the computed potentiometric heads and the measured water levels obtained for the steadystate model and the three transient-model calibration periods.

\section{Calibration Period 1: 1895-1914}

By 1914-the end of the second pumping periodground-water withdrawals from the aquifer system in the model area were about $2,100 \mathrm{Mgal} / \mathrm{yr}$ (table 3). The second model pumping period is the first transient-model calibration period. Figure 16 shows the composite potentiometric surface for aquifers 1 and 2 at the end of 1914.

The data points shown in figure 16 are water levels from wells reported by Weidman and Schultz (1915). Because the well construction, date and method of water-level measurement, and the specific aquifers open in each of the wells are not generally known, the accuracy of the water-level measurements and the interpretation of what aquifers it represents are uncertain. The water levels are, however, the best data available to verify the computed potentiometric surface. Assuming the water-level measurements are representative of the composite potentiometric heads of aquifers 1 and 2 , the computed potentiometric surface agrees fairly well with the reported head data. Those measurements that do not agree as well probably represent wells that are open to aquifers 1,2 , and 3 or aquifers 2 and 3 . The water levels reported by Weidman and Schultz (1915) were also used to calculate the 1914 model differences shown in table 4. The table indicates that the average arithmetic difference between the computed composite aquifer 1 and 2 potentiometric heads and the corresponding reported water levels of Weidman and Schultz (1915) was $-9.9 \mathrm{ft}$ and the average absolute difference was $37.2 \mathrm{ft}$.

This model output indicates that ground-water withdrawals had already affected the aquifer system by 1914 . 


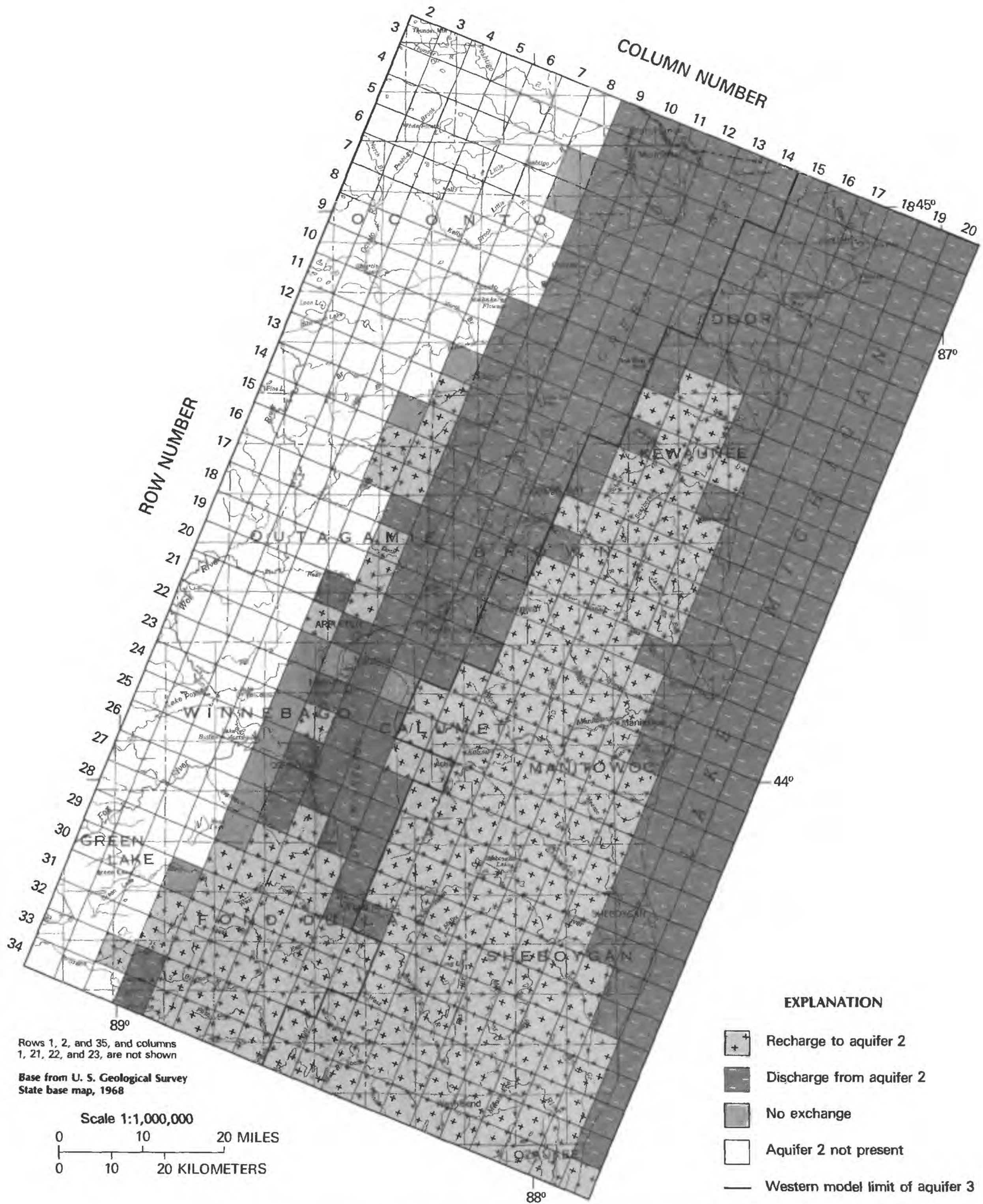

Figure 15. Prepumping vertical water movement between aquifer 2 and overlying aquifer. 


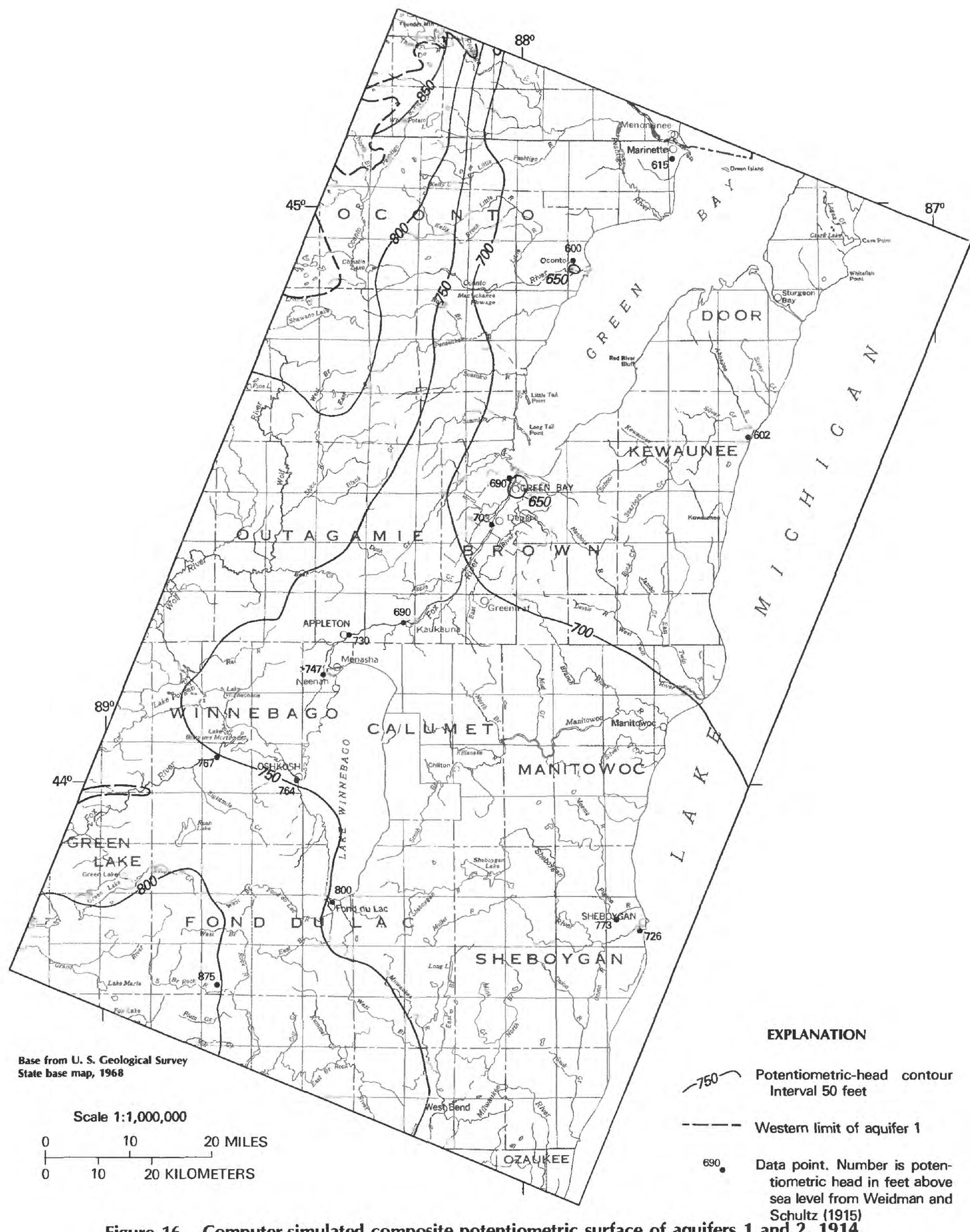

Figure 16. Computer-simulated composite potentiometric surface of aquifers 1 and 2, 1914. 
The area around the city of Green Bay shows the beginnings of a cone of depression (fig. 16). The model indicates groundwater withdrawals in the city of Green Bay area had lowered the nonpumping potentiometric heads as much as $69 \mathrm{ft}$ in aquifer 1 and $55 \mathrm{ft}$ in aquifer 2 . Although not evident in figure 16 , the model indicates ground-water withdrawals in the city of Fond du Lac area had reduced the prepumping heads by as much as $39 \mathrm{ft}$ in aquifer 1 and $30 \mathrm{ft}$ in aquifer 2 . Also in the vicinity of the city of Oconto the model indicates aquifer 1 had been lowered by as much as $41 \mathrm{ft}$ and aquifer 2 by as much as $39 \mathrm{ft}$ below their model computed prepumping potentiometric heads.

\section{Calibration Period 2: 1895-1957}

Since 1914, increasing ground-water withdrawals have occurred in the study area, with a corresponding decline in the potentiometric heads in the aquifers. The seventh model pumping period ending in 1957 is the second transient modelcalibration period.

The composite potentiometric surface of aquifers 1 and 2 is shown in figure 17 and the individual potentiometric surfaces are shown in figure 18 and 19 , respectively. Thirtynine water-level measurements were identified as being made on wells open to both aquifers 1 and 2 . There is fairly good agreement between the measured water levels and the computed composite potentimetric surface of aquifers 1 and 2 . The average arithmetic difference between the composite potentiometric surface and the measured water level is -2.1 $\mathrm{ft}$ and the absolute difference is $55.7 \mathrm{ft}$ (table 4). Only one water-level measurement was identified as being from a well completed in aquifer 1 and it was made in 1954. The 1954 measurement is in fair agreement with corresponding model computed potentiometric head. The average arithmetic difference between the computed head and the measured water level was $-65 \mathrm{ft}$ and the absolute difference was $65 \mathrm{ft}$. Water-level measurements from 44 wells completed in aquifer 2 were identified. There is fairly good agreement between these reported water-level data points and the computed potentiometric surface for aquifer 2 (fig. 19). The average arithmetic difference between the computed potentiometric surface and the measured water level for aquifer 2 was $-33.9 \mathrm{ft}$ and the average absolute difference was 49.7 $\mathrm{ft}$ (table 4).

By 1957, ground-water withdrawals in the modeled area had increased to an average rate of $13,100 \mathrm{Mgal} / \mathrm{yr}$ (table 3). Nearly 29 percent of the pumpage was concentrated in Brown County. As a result, a large cone of depression had formed around the city of Green Bay, as shown in figure 17. At the end of 1957, model computed drawdowns below the prepumping potentiometric heads at Green Bay were 437 $\mathrm{ft}$ in aquifer 1 and $386 \mathrm{ft}$ in aquifer 2. Knowles (1964) reports that by 1957 , measured composite nonpumping water levels near the center of the cone of depression had declined about
$340 \mathrm{ft}$ below land surface which was about $437 \mathrm{ft}$ below the reported prepumping water levels.

The area around the city of Fond du Lac had experienced a similar but less severe drawdown as a result of increased pumpage from aquifers 1 and 2. Computed drawdowns in 1957 are $123 \mathrm{ft}$ in aquifer 1 and $85 \mathrm{ft}$ in aquifer 2. Newport (1962) reports that between 1885 and 1956, the water-level decline in a well in the center of the cone of depression was $91 \mathrm{ft}$. It is assumed that the well is open to both aquifers 1 and 2 but there are no data to substantiate this assumption. The steady-state model potentiometric head in the city of Fond du Lac area was $33 \mathrm{ft}$ higher than reported by Weidman and Schultz (1915). As a result, the 1957 modelcomputed drawdown is $33 \mathrm{ft}$ higher than the drawdown reported by Newport (1962).

Olcott (1966) reports that, by 1963, the water level in the city of Oshkosh area had been lowered by 25 to $30 \mathrm{ft}$ below the 1915 levels reported by Weidman and Schultz (1915). The model-computed drawdowns for the Oshkosh area between 1915 and 1957 are $76 \mathrm{ft}$ for aquifer 1 and 47 $\mathrm{ft}$ for aquifer 2. Between 1915 and 1964, the model-computed drawdowns are $88 \mathrm{ft}$ for aquifer 1 and $49 \mathrm{ft}$ for aquifer 2 . The discrepancy between the reported and model-computed drawdowns in the city of Oshkosh area suggests that the aquifers are receiving more recharge from Lake Winnebago and Lake Butte des Morts than the model predicts.

By 1963, the Neenah-Menasha area had experienced water-level declines of 110 to $120 \mathrm{ft}$ below the 1915 water levels. The model-computed drawdowns between 1915 and 1957 are $121 \mathrm{ft}$ for aquifers 1 and 2. Model-computed drawdowns between 1915 and 1964 are $137 \mathrm{ft}$ for aquifer 1 and $122 \mathrm{ft}$ for aquifer 2 .

In the center of the cone of depression in the city of Green Bay area, the measured composite potentiometric head was about $300 \mathrm{ft}$ above sea level in 1957. The modelcomputed composite head for aquifers 1 and 2 is $307 \mathrm{ft}$ above sea level for 1957.

In and near the city of Fond du Lac, the center of the cone of depression was about $600 \mathrm{ft}$ above sea level in 1956, whereas the composite model potentiometric head was 664 $\mathrm{ft}$ above sea level in 1957. Measured composite water level for the area in and near the city of Oshkosh was approximately $730 \mathrm{ft}$ above sea level-in 1963 . The computed composite head for the area was $684 \mathrm{ft}$ above sea level in 1957 and $676 \mathrm{ft}$ above sea level in 1964.

According to Olcott (1966), the center of the cone of depression in the Neenah-Menasha area had an altitude of about $630 \mathrm{ft}$ above sea level in 1963. The model computed composite potentiometric head was $608 \mathrm{ft}$ above sea level in 1957 and $598 \mathrm{ft}$ above sea level in 1964.

The greatest impact on the aquifer system due to pumping had occurred by 1957 . The composite potentiometric surface of aquifers 1 and 2 (fig. 17) and the individual surfaces of aquifers 1 and 2 (figs. 18-19) show the effects of pumping. The potentiometric surfaces indicate that major 


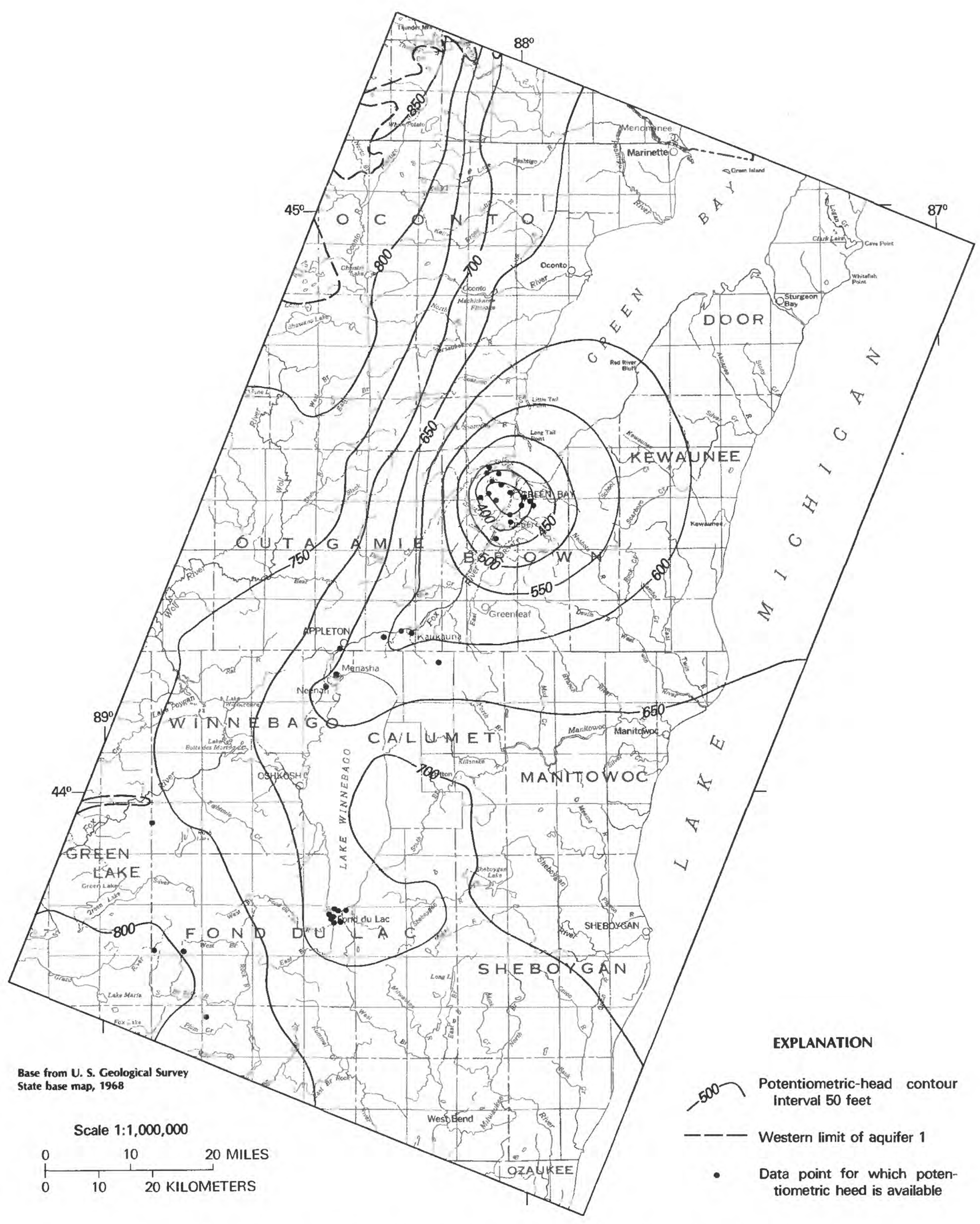

Figure 17. Computer-simulated composite potentiometric surface of aquifers 1 and 2, 1957. 


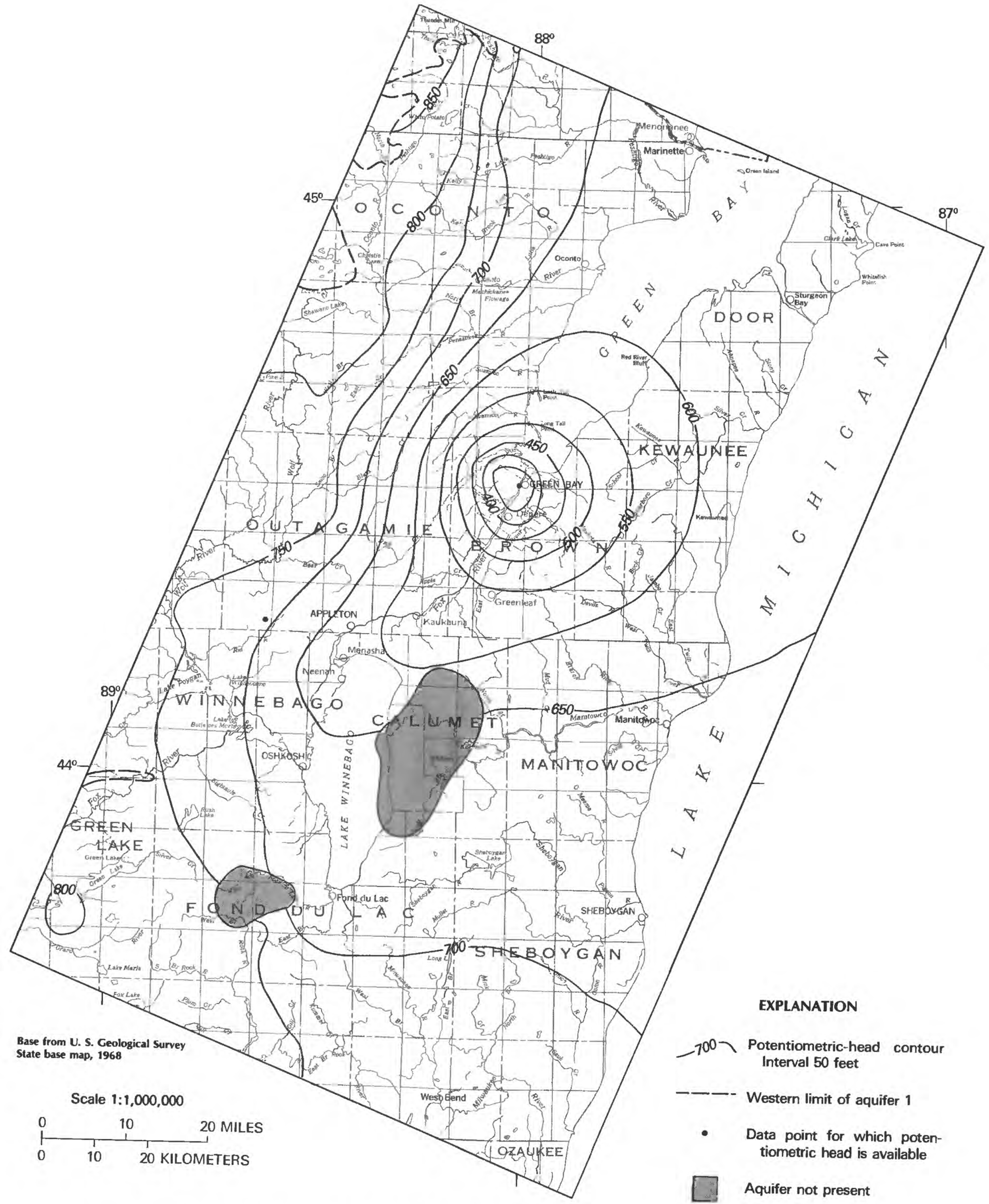

Figure 18. Computer-simulated potentiometric surface of aquifer 1, 1957. 


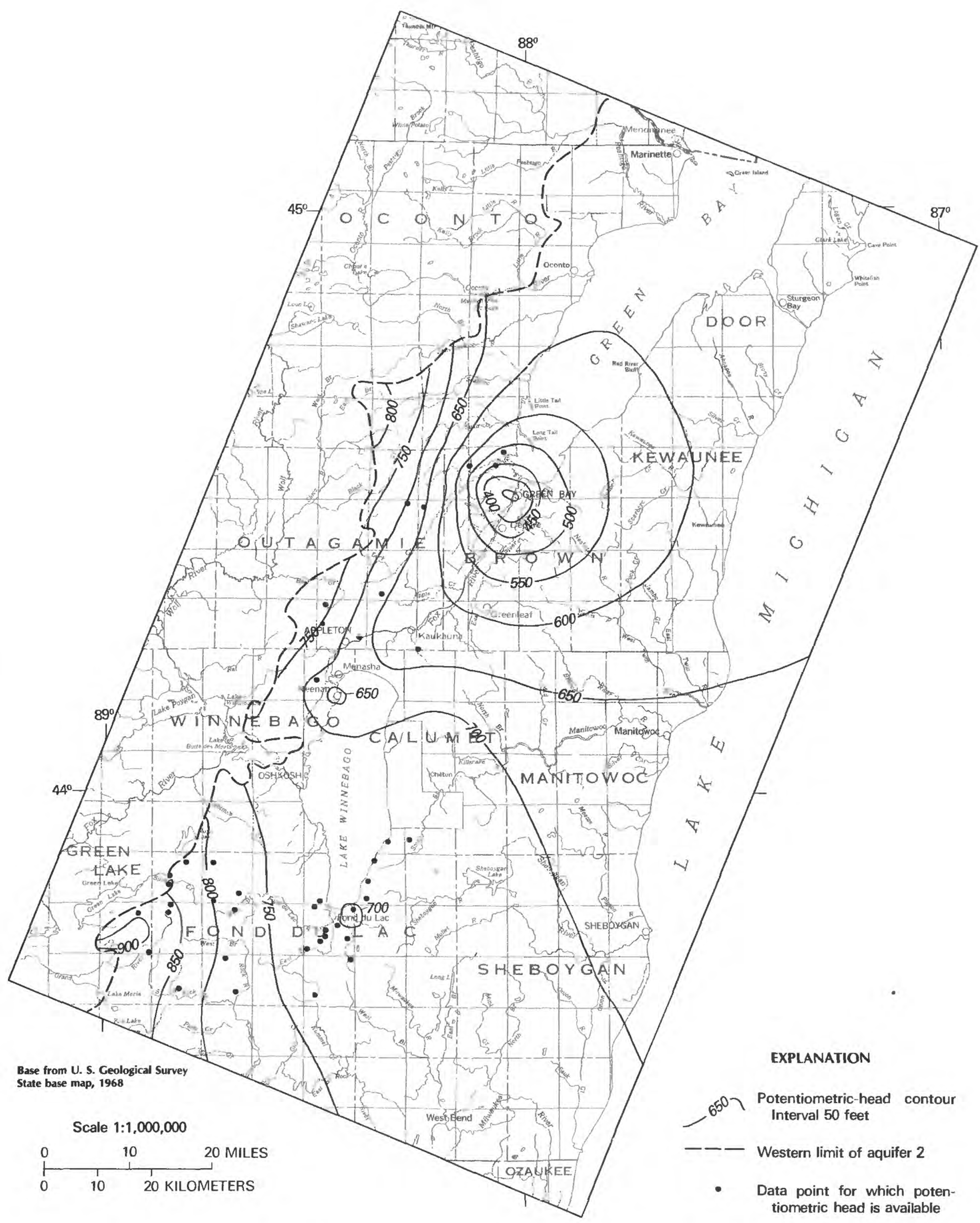

Figure 19. Computer-simulated potentiometric surface of aquifer 2, 1957. 
pumping centered in the Green Bay area, along with smaller pumping centers in the lower Fox River Valley, have affected most of the study area. The direction of ground-water flow, which was generally to the northeast before pumping began, is now controlled primarily by the large cone of depression. Much of the water that formerly flowed out of the study area is now captured by the cone. In the northeastern part of the study area, the direction of prepumping ground-water flow has been reversed.

Where aquifer 1 is not present (fig. 18), there can be no vertical flow between aquifer 1 and 2 . As a result, there is a mound of water in aquifer 2 in these areas, as evidenced by the slight northerly bow of the $700-\mathrm{ft}$ contour just east of Lake Winnebago (fig. 19). The distortion of the 700-ft contour on figure 17 is the result of the method used to compute the composite head. The aquifer 2 potentiometric head is used as the composite head in the areas where aquifer 1 is not present. The existence or importance of the mound in aquifer 2 cannot be verified as there are no water-level data in this area.

\section{Calibration Period 3: 1895-1981}

The tenth model pumping period, ending in 1981, is the third and last pumping period on which the transient model was calibrated. With few exceptions, the ground-water withdrawals in the study area had continued to increase since the drop in 1957. By 1981, withdrawals from the aquifer system in the study area were $17,204 \mathrm{Mgal} / \mathrm{yr}$ or about a 31 percent increase over 1957 pumpage (table 3).

The major exception to increased ground-water withdrawals was the city of Green Bay. In 1957, the city converted to Lake Michigan for their primary water supply, with a decrease in ground-water pumpage from a maximum rate of 4,781 to $1,934 \mathrm{Mgal} / \mathrm{yr}$ (Knowles, 1964). As a result, the potentiometric heads in the cone of depression in and near the city of Green Bay rose rapidly, as shown on the hydrographs of Bn-9 and Bn-13 (fig. 20). The water level in well $\mathrm{Bn}-9$ near the center of the cone rose approximately $250 \mathrm{ft}$ by 1960 . The maximum recorded water-level rise was $288 \mathrm{ft}$, in a well in the city of Green Bay.

Since the 1957 decrease in withdrawal from aquifers 1 and 2 in and near the city of Green Bay, the pumpage has steadily increased, which has resulted in a renewed decline in the potentiometric heads in the aquifer system. The potentiometric heads in the remainder of the study area have either remained constant or declined (fig. 20).

The computed composite potentiometric surface of aquifers 1 and 2, and the water-level-data points locating wells open to aquifers 1 and 2 are shown in figure 21 . Fortynine composite water-level measurements of aquifers 1 and 2 measured between 1970 and 1980 were used to check the accuracy of the model-computed composite potentiometric surface. The model-produced 1981 potentiometric-surface maps were considered acceptable when the contours on the maps adequately represented the corresponding observed point data or clusters of point data. Acceptance was also based on the best composite set of average arithmetic and absolute differences between the computed potentiometric heads and the measured water levels obtained for the steadystate model and the three transient calibration periods (table 4). The average arithmetic difference between the computed 1981 composite aquifer 1 and 2 potentiometric heads and the corresponding measured water levels was $1.0 \mathrm{ft}$ and the average absolute difference was $33.7 \mathrm{ft}$.

Figure 22 shows the computed potentiometric surface and the water-level-measuring points for aquifer 1 . Only 11 wells completed in aquifer 1 had water levels measured between 1970 and 1980. All but two of the measurements indicate that the computed potentiometric contours are within acceptable limits. The two measurements indicate that the center of the cone in and near the city of Green Bay should be approximately $2 \mathrm{mi}$ northeast of its presently computed location. This discrepancy probably is a result of the nodal size $(19,792 \mathrm{ft})$, which shifted the center of the pumping too far to the southwest. The model computes all pumpage within a grid block as a single well located at the center of the node. If the pumpage occurs near the edge of a grid block, the pumpage could be displaced nearly $2 \mathrm{mi}$. Table 4 indicates that the average arithmetic difference between the computed aquifer 1 potentiometric heads and the 11 corresponding measured water levels was $-21.5 \mathrm{ft}$ and the average absolute difference was $70.0 \mathrm{ft}$. If the water levels in the city of Green Bay area are eliminated, the average arithmetic difference becomes $55.9 \mathrm{ft}$ and the absolute difference, $56 \mathrm{ft}$.

The computed potentiometric surface of aquifer 2 in 1981 and the water-level data points that locate wells open only to aquifer 2 are shown in figure 23 . One hundred and thirty water-level measurements were made between 1970 and 1980 in wells completed only in aquifer 2 . The number of wells shown in figure 23 is somewhat fewer because some of the wells have several water-level measurements and others may represent several wells at approximately the same location. Overall, the computed potentiometric contours are visually within acceptable limits. There are, however, a few points that do not fit. These water levels are lower than the computed potentiometric values, and probably represent pumping or partially recovered potentiometric heads because measurements from nearby wells are acceptable. The average arithmetic difference between the computed aquifer 2 potentiometric heads and the 130 corresponding measured water level was $-5.2 \mathrm{ft}$ and the average absolute difference was $34.4 \mathrm{ft}$.

The large lobe in the 700 - $\mathrm{ft}$ contour of aquifer 2 shown in figure 23 is the result of aquifer 1 not being present in this area. Because aquifer 1 is not present, there can be no vertical flow between aquifers 1 and 2 , and a ground-water mound is modeled in aquifer 2 . The presence or importance of the mound cannot be verified because there are no waterlevel data in this area. 

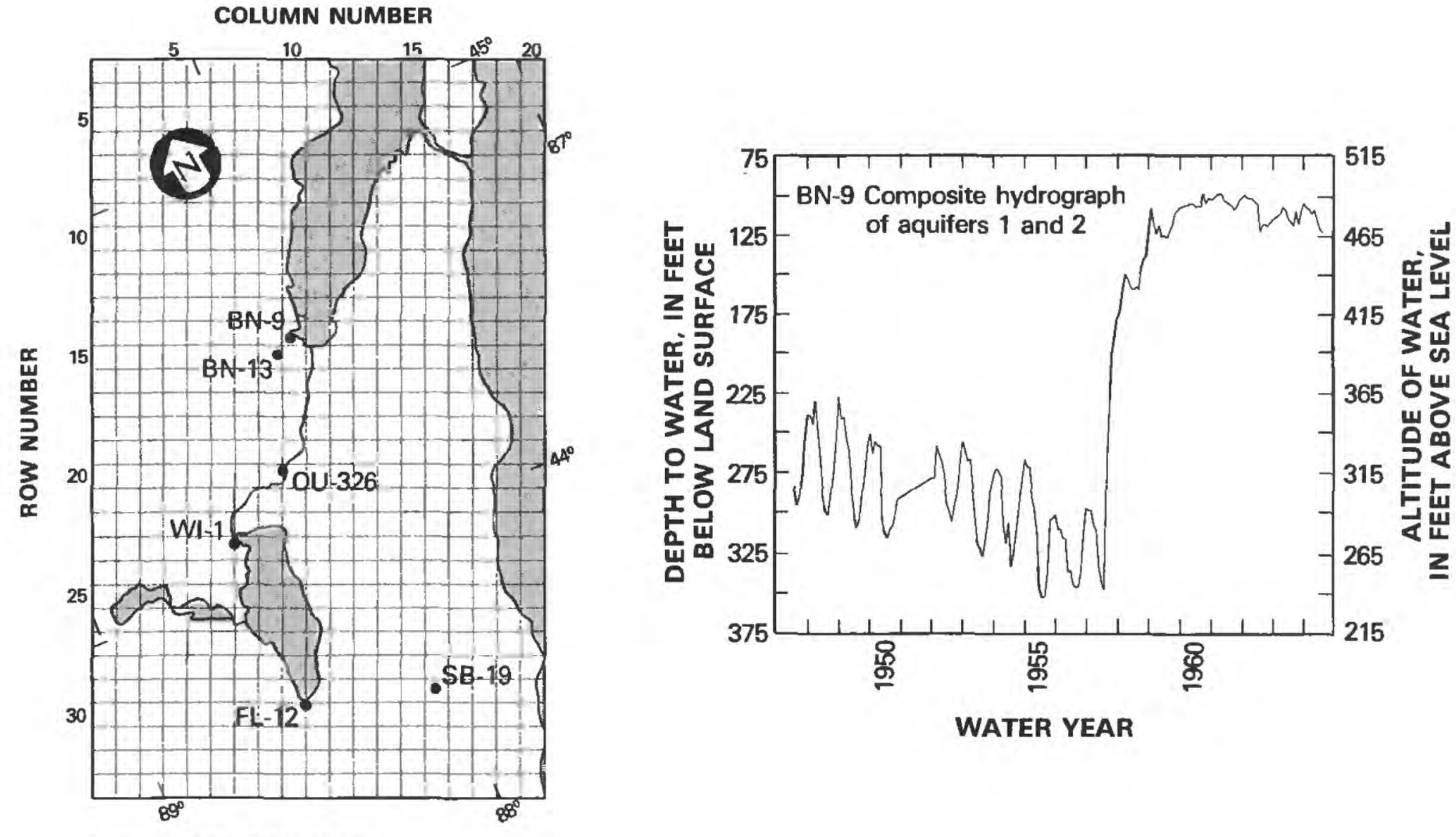

WELL LOCATION MAP

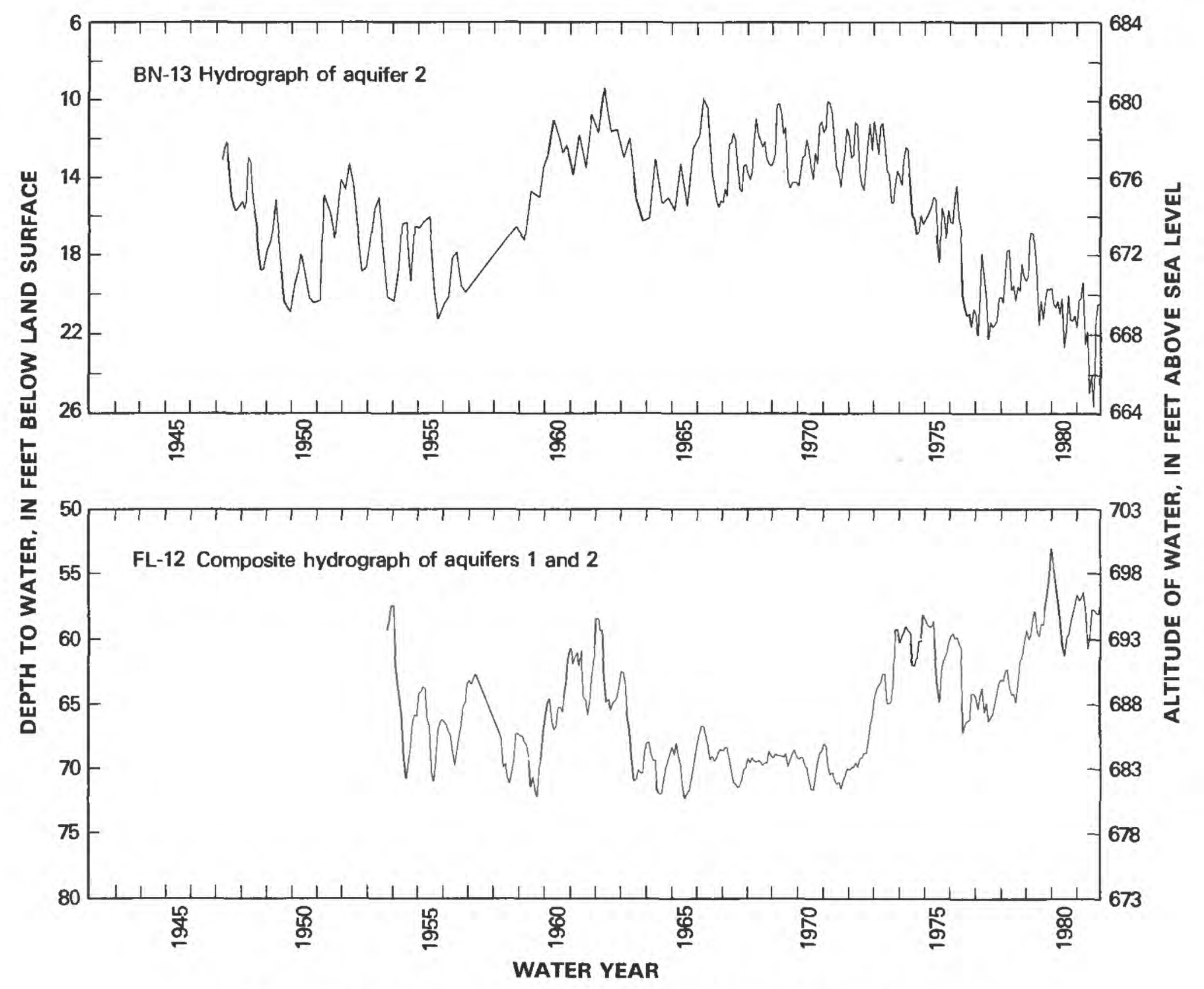

Figure 20. Selected hydrographs used for model calibration. 

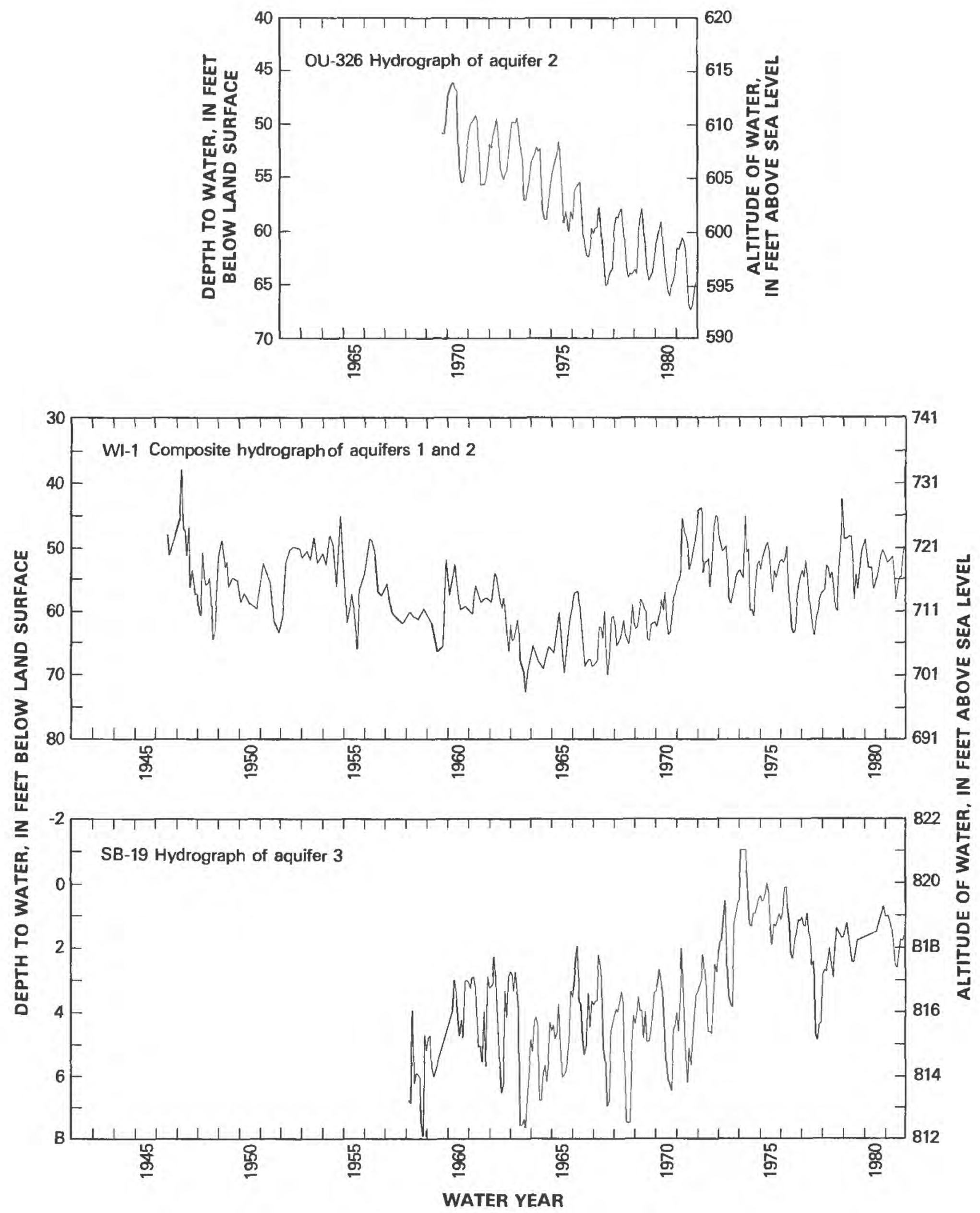


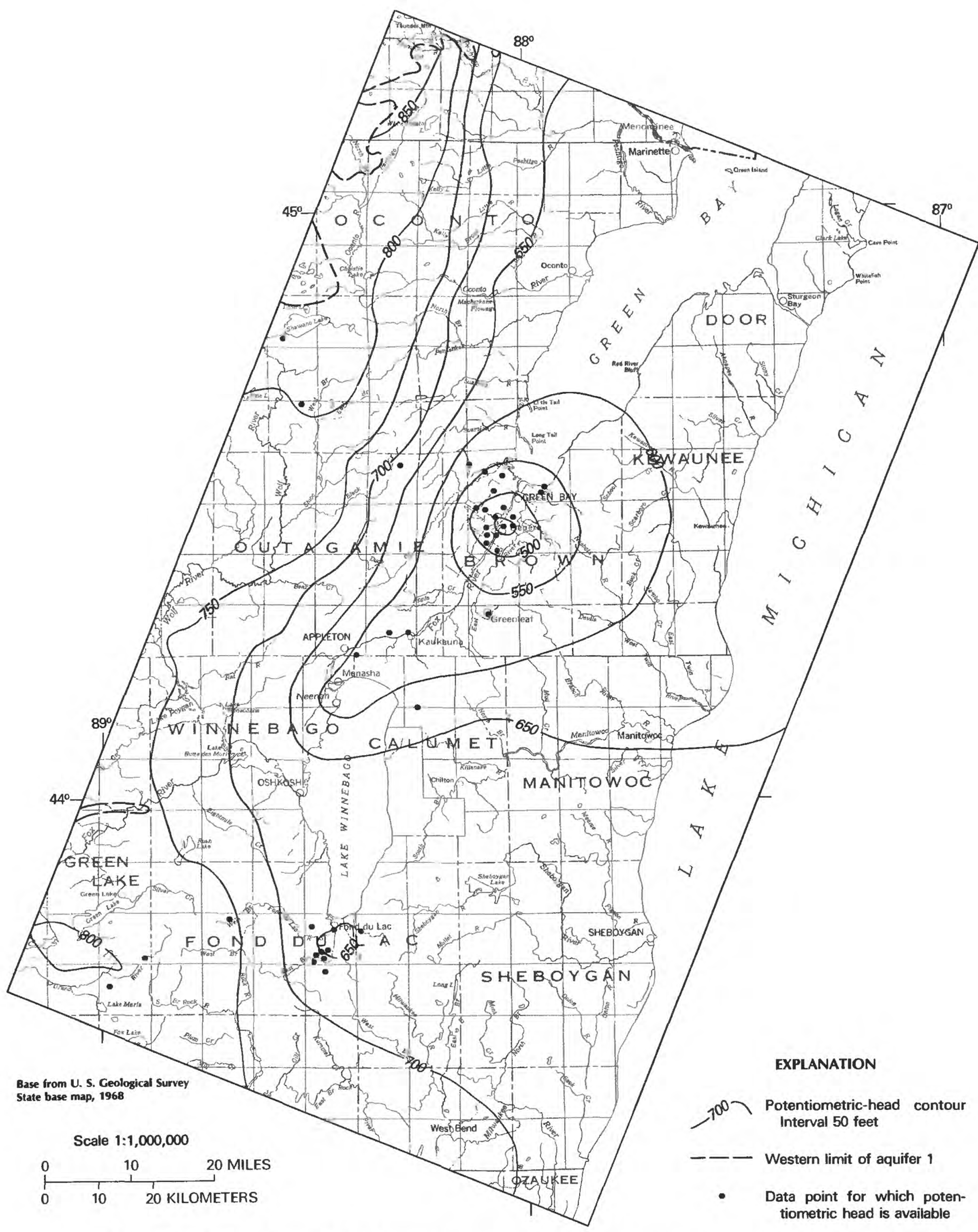

Figure 21. Computer-simulated composite potentiometric surface of aquifers 1 and 2, 1981. 


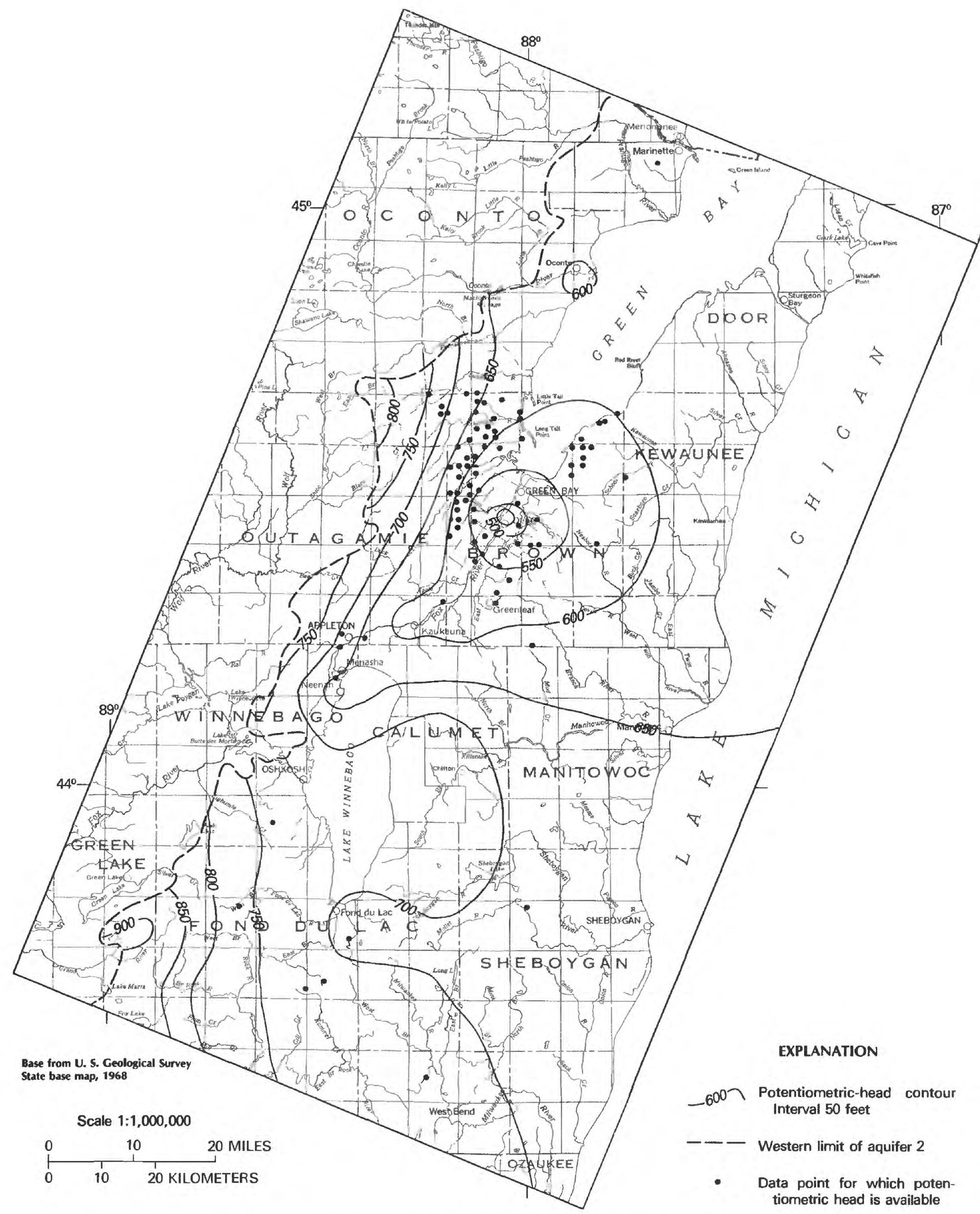

Figure 23. Computer-simulated potentiometric surface of aquifer 2, 1981. 
The computed potentiometric surface of aquifer 3 in 1981 is shown on figure 24 . Although the potentiometric head in aquifer 3 may fluctuate seasonally, no major long-term declines in the potentiometric heads have occurred as indicated by a typical hydrograph of an aquifer 3 well shown in figure 20. Because the predevelopment potentiometric surface of aquifer 3 and the water table in aquifer 4 are nearly identical and no long-term declines have occurred, the more than 1,000 data points used to construct the prepumping potentiometric-surface map for aquifer 4 can also be used to verify the 1981 potentiometric surface map for aquifer 3 . There is good agreement between the observed data points and computed potentiometric surface of aquifer 3 .

\section{Potentiometric Surfaces}

The 1981 composite potentiometric-surface map of aquifers 1 and 2 (fig. 21) shows a large cone of depression centered in and near the city of De Pere and extending southwest up the Fox River Valley to Lake Winnebago. A small cone of depression is also shown in the city of Fond du Lac area. Shallow cones of depression are also present in the cities of Neenah and Menasha and in the city of Kaukauna areas, but do not show on figure 21 because their depth is less than the 50 - $\mathrm{ft}$ contour interval. No cone of depression is present in the computed composite potentiometric heads for the city of Oshkosh area. The 1981 potentiometric-surface map of aquifer 1 (fig. 22) shows that the large cone of depression consists of the major cone centered in the De Pere area and two small cones centered in and near the city of Kaukauna and the cities of Neenah and Menasha. As a result of the 50-ft contour interval used to define the computed potentiometric surface of aquifer 1 , a small cone of depression in the city of Fond du Lac area is not shown. The center of the aquifer 1 cone is located slightly to the southwest of the city of Fond du Lac. The computed potentiometric heads for aquifer 1 do not show a cone of depression in the Oshkosh area. The 1981, aquifer 2 potentiometric-surface map (fig. 20) shows only the large cone of depression centered in the De Pere area.

The large cone of depression, centered in and near the city of De Pere, has the lowest potentiometric heads in the study area. In the center of the cone, the computed composite head is $425 \mathrm{ft}$ above sea level. The computed head in aquifer 1 is $402 \mathrm{ft}$ above sea level and the head in aquifer 2 is 462 $\mathrm{ft}$ above sea level.

In the Kaukauna area, where the model indicates a small cone of depression has formed, the 1981 computed composite potentiometric head is $551 \mathrm{ft}$ above sea level. The computed potentiometric head in aquifer 1 is $540 \mathrm{ft}$ above sea level and in aquifer 2 is $572 \mathrm{ft}$ above sea level.

The Neenah-Menasha area, which is located near the southern end of the large cone, has a 1981 computed com- posite head of $569 \mathrm{ft}$ above sea level. In aquifer 1, the model computed head is $545 \mathrm{ft}$ above sea level and in aquifer 2 the head is $602 \mathrm{ft}$ above sea level.

There is no defined 1981 cone of depression in the computed potentiometric heads for the composite aquifer 1 and 2 or for aquifer 1 alone in the Oshkosh area. The $1981 \mathrm{com}-$ puted composite head in the grid block containing the city of Oshkosh is $663 \mathrm{ft}$ above sea level. The computed potentiometric head in aquifer 1 is $624 \mathrm{ft}$ above sea level and the head in aquifer 2 where a small cone of depression is present, is $703 \mathrm{ft}$ above sea level.

In the Fond du Lac area, the 1981 computed composite potentiometric head is $639 \mathrm{ft}$ above sea level. In this area, the lowest computed head in aquifer 1 was $595 \mathrm{ft}$ above sea level and for aquifer 2 was $686 \mathrm{ft}$ above sea level. The lowest potentiometric heads for aquifers 1 and 2 at Fond du Lac were located in nodes adjacent to each other. Having the lowest potentiometric heads of both aquifers in different nodes is probably the result of the distribution of the groundwater withdrawals from each of the aquifers. When the distribution of ground-water pumpage from aquifers 1 and 2 changes significantly in adjacent nodes, the minimum potentiometric head in each of the aquifers may also be in different nodes.

\section{Drawdowns}

The computed drawdowns in 1981 below the computed prepumping potentiometric surfaces in aquifers 1 and 2 are shown in figures 25 and 26 . The drawdown patterns in each of the aquifers closely resemble the cones of depression. Computed drawdowns in aquifer 1 range from $0 \mathrm{ft}$ on the western side of the study area where the aquifer is under water-table conditions to $330 \mathrm{ft}$ in the center of the cone of depression in the De Pere area. In aquifer 2, the computed drawdowns range from $0 \mathrm{ft}$ on the western side of the study area to $253 \mathrm{ft}$ in the center of the cone.

In the Kaukauna area, the maximum computed 1981 drawdown in aquifer 1 is $212 \mathrm{ft}$ and in aquifer 2 is $176 \mathrm{ft}$. The maximum computed drawdown in Neenah-Menasha area is $213 \mathrm{ft}$ in aquifer 1 and $151 \mathrm{ft}$ in aquifer 2 . In the Oshkosh area, the computed drawdown in aquifer 1 is $136 \mathrm{ft}$ and in aquifer 2 is $59 \mathrm{ft}$. Maximum computed drawdown below the prepumping potentiometric surface in the Fond du Lac area is $176 \mathrm{ft}$ in aquifer 1 and $88 \mathrm{ft}$ in aquifer 2 . In the Oshkosh and Fond du Lac areas, the maximum computed drawdowns in aquifers 1 and 2 do not occur in the same nodes. The difference is probably a result of the pumpage distribution between the two aquifers.

The model computed maximum drawdown in aquifer 3 in the modeled area did not exceed $5 \mathrm{ft}$, although seasonally the drawdowns in some areas may be greater. 


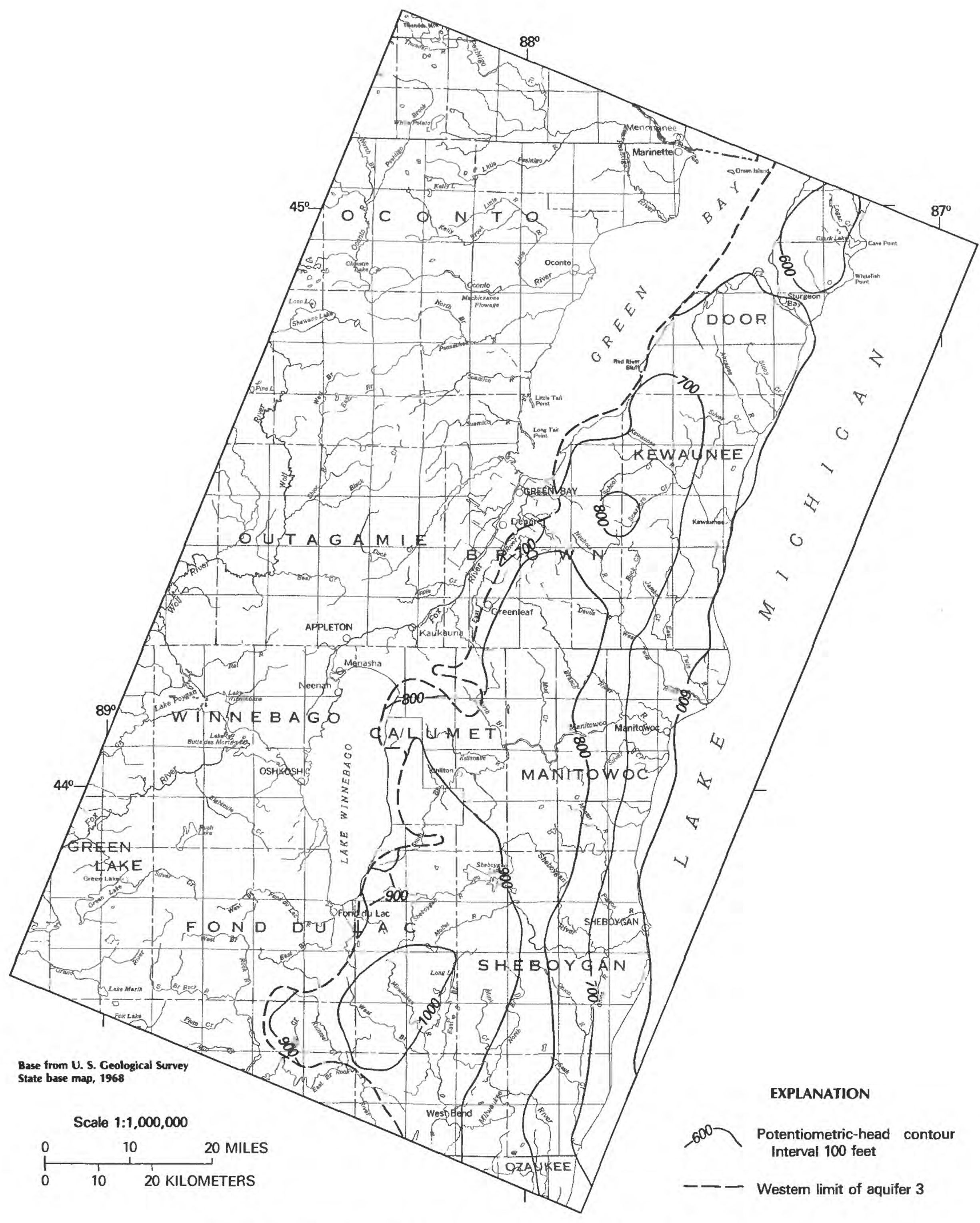

Figure 24. Computer-simulated potentiometric surface of aquifer 3, 1981. 


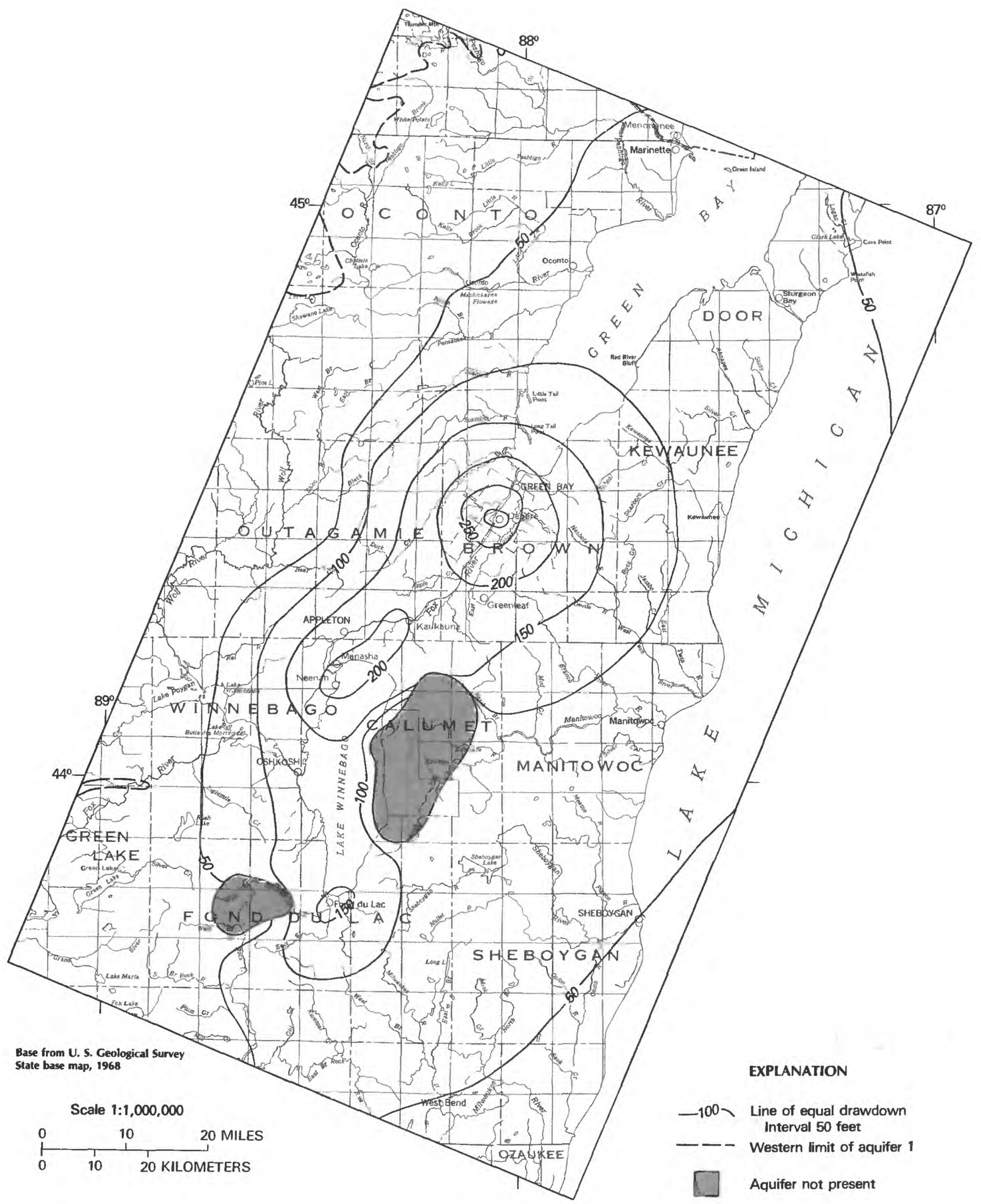

Figures 25. Computer-simulated drawdown of the potentiometric surface of aquifer 1, prepumping through 1981. 


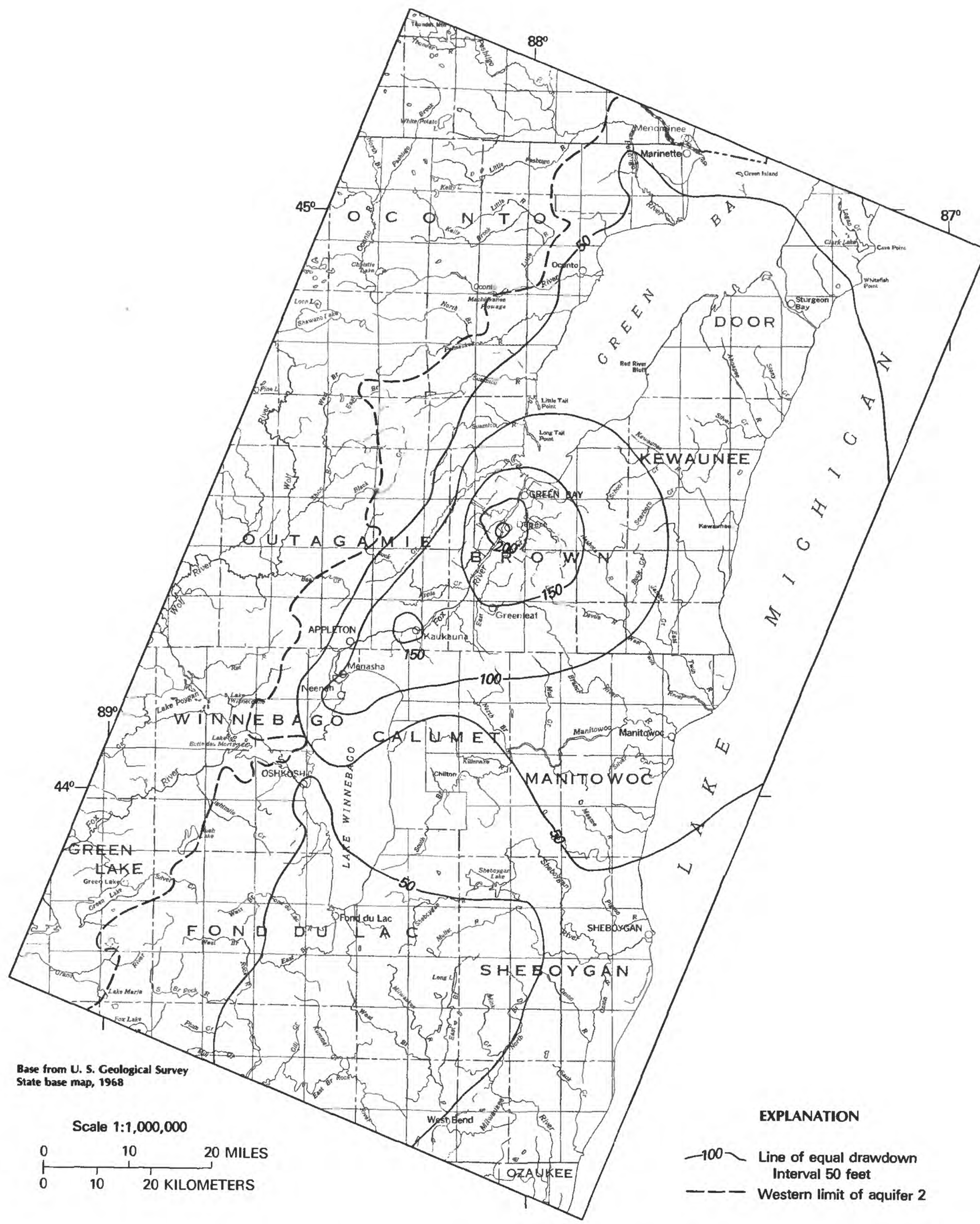

Figure 26. Computer-simulated drawdown of the potentiometric surface of aquifer 2, prepumping through 1981. 


\section{Ground-Water Flow}

The direction of flow in aquifer 1 is very similar to that in 2, as determined from the 1981 potentiometric surface maps (fig. 22 and 23). The large cone of depression centered in and near the city of De Pere captures much of the groundwater flow in the study area. Smaller amounts also are captured locally by the cones of depression around Kaukauna, Neenah-Menasha, and Fond du Lac.

Ground-water flow in aquifer 1 in the western part of the modeled area generally is east into the large cone of depression, except in the southwestern corner where the flow is northeast into the southern extent of the cone. In the northwestern corner of the area, a small flow may escape the study area to the northeast. Throughout the central part of the area, all of the water flows into the cone of depression. Groundwater movement in the southeast is divided with some flowing north and west into the cone and some flowing north and east out of the area. In the area east of the Fox River Valley and the southern part of Green Bay, the ground-water movement is westerly into the cone. In the northeastern part of the area, the ground-water gradient is flat to sloping slightly into the cone.

The direction of ground-water flow has changed significantly in aquifer 1 since prepumping conditions (fig. 12). Under prepumping conditions, the movement of water in aquifer 1 was essentially to the northeast. Movement in the aquifer in much of the study area is now into the large cone of depression created by pumping. These changes in direction now capture water that previously flowed out of the area. The changes in the regional flow directions could result in long-term changes in the water quality in the aquifer by inducing the flow of water that had previously flowed out of the area into the cone of depression created by municipal and industrial pumpage.

Ground-water flow in aquifer 2 (fig. 23) on the western side of the study area generally is to the east into the large cone of depression. The potentiometric high in the southwestern corner of the area causes the ground-water flow to radiate outward in all directions. Much of this water eventually flows into the large cone of depression; however, some flows out of the area to the west, south, and east. Through the central part of the study area, the flow generally is into the cone of depression, whereas in the southeast, much of the flow is to the east out of the area. In the northeast, the potentiometric surface has only a very slight gradient toward the cone. This very low gradient may indicate that the northeast edge of the cone is in Door County.

As with aquifer 1, the direction of water movement in aquifer 2 has changed significantly since prepumping conditions (fig. 13). The direction of flow in aquifer 2 under prepumping conditions generally was to the northeast. By 1981 , the large cone of depression in the study area captured much of the ground-water flow that previously flowed out of the study area. The changes in direction and the introduction of water into the area that previously flowed out could, over a period of time, result in changes to the water quality in the aquifer.

The direction of flow in aquifer 3 is the same as the direction of prepumping flow. The ground-water flow follows very closely the surface drainage. On the western side of the study area, the flow generally is to the east into Green Bay or the Fox River Valley or north and south into the Lake Poygan and Lake Butte des Morts area. Flow from the topographically high area between them generally is westward into Green Bay, Fox-River Valley, and Lake Winnebago and eastward into Lake Michigan.

The vertical recharge and discharge to and from aquifers 1 and 2 are shown in figures 27 and 28 and were determined based on potentiometric head differences between aquifers. Recharge to the aquifer occurs when the potentiometric head in the overlying aquifer is higher than the head in the aquifer.

Discharge from the aquifer occurs when the head in the overlying aquifer is lower than the head in the aquifer.

In 1981, recharge to aquifer 1 from aquifer 2 occurred in most of the southern two-thirds of the study area (fig. 27). Discharge from aquifer 1 to aquifer 2 occurred only along the eastern edge and in the northeastern part of the area. Along the very western edge of the study area and near the Lake Michigan shoreline, the potentiometric heads in aquifers 1 and 2 are equal. The recharge-discharge relationship in aquifer 1 has changed significantly since prepumping conditions (fig. 14). Under prepumping conditions, the area east from Green Bay south to Lake Winnebago, including the lower Fox River Valley, was a discharge area. By 1981, potentiometric-head reversal had occurred in much of this area so that this area is no longer a discharge area. The head reversal has a significant effect on the aquifer system flow regime.

Recharge to aquifer 2 from aquifer 3 occurred throughout most of the western three-quarters of the study area with the exception of the Green Bay area and the northern part of the Door County Penninsula. Discharge from aquifer 2 into aquifer 3 occurred also in the Lake Michigan area. Along the western edge of the study area, the potentiometric heads of aquifers 2 and 3 are equal. The rechargedischarge relationship in aquifer 2 also has changed significantly since prepumping conditions (fig. 15). The Lake Winnebago and lower Fox River Valley area originally was a discharge area for aquifer 2 . Since 1981, the entire area is a recharge area. As with aquifer 1 , these head reversals impact significantly on the aquifer-system flow regime. 


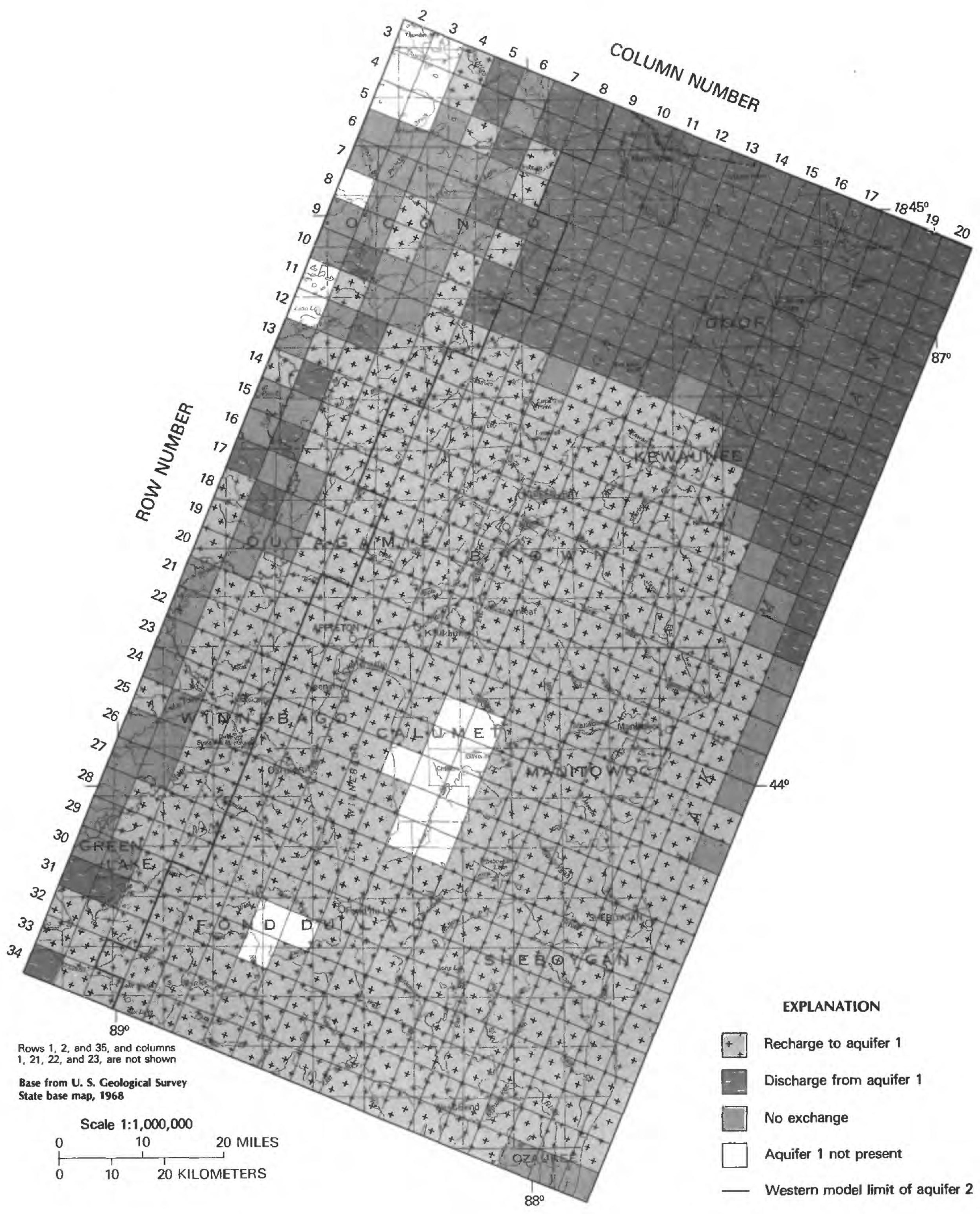

Figure 27. Vertical water movement between aquifer 1 and overlying aquifer. 


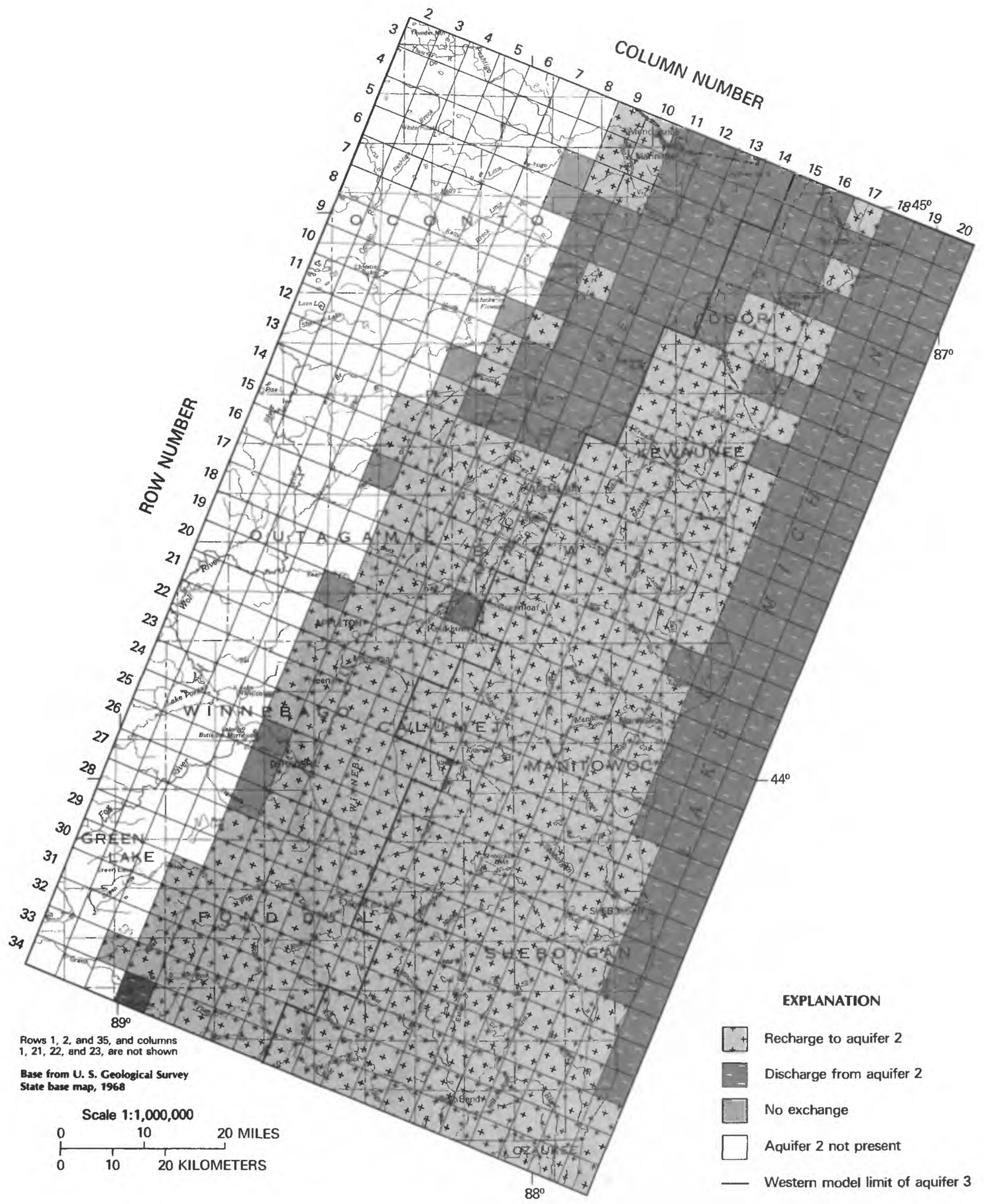

Figure 28. Vertical water movement between aquifer 2 and overlying aquifer. 


\section{SUMMARY AND CONCLUSIONS}

Ground water is a major source of water in northeastern Wisconsin. The recharge movement and discharge of the ground water is controlled by the lithology and stratigraphy of the geologic units. The purpose of this study was to evaluate the bedrock aquifer system in northeastern Wisconsin and determine how the flow regimes in the system have been altered due to ground-water withdrawals. In order to simplify the study of the aquifer system, the geologic units were grouped into eight geohydrologic units consisting of four aquifers and four confining beds. The aquifers are the more permeable sand and gravel layers in the surficial deposits (aquifer 4), Devonian dolomite-Silurian dolomite (aquifer 3), St. Peter Sandstone-Prairie du Chien GroupJordan Sandstone Member of the Trempealeau Formation (aquifer 2), and the Galesville Sandstone-Eau Claire Sandstone-Mount Simon Sandstone (aquifer 1). The confining beds are the less permeable silts and clays in the surficial deposits (confining bed 4), Maquoketa Shale-Galena Dolomite-Decorah Shale-Platteville Formation (confining bed 3), St. Lawrence Member of the Trempealeau Formation-Franconia Sandstone (confining bed 2), and the Precambrian crystalline rock (confining bed 1).

All existing geohydrologic data for the four aquifers and four confining beds were collated and evaluated. These data were also used in the development of a quasi threedimensional finite-difference ground-water flow model of the bedrock aquifer system.

Aquifer 4 is in hydrologic equilibrium, with recharge equaling discharge. The water table in aquifer 4 is at or very near its prepumping water levels. Aquifer 4 acts as an upper boundary of the bedrock aquifer system. Aquifer 3 is the uppermost bedrock aquifer unit. The hydraulic conductivity calculated from specific-capacity data for aquifer 3 ranges from 0.017 to $8,000 \mathrm{ft} / \mathrm{d}$, with a geometric mean of $7.9 \mathrm{ft} / \mathrm{d}$. The storage coefficient of the aquifer was estimated to be 0.01 . The hydraulic conductivity, calculated from specific-capacity data for aquifer 2, ranged from 1.3 to 110 $\mathrm{ft} / \mathrm{d}$ with a geometric mean of $10 \mathrm{ft} / \mathrm{d}$. Transmissivity values calculated from aquifer tests better represented aquifer 2 than did the geometric mean value for hydraulic conductivity. Therefore, zoned hydraulic conductivity values ranging from 3.1 to $8.3 \mathrm{ft} / \mathrm{d}$ were used in the calculation of model input transmissivity values. Storage coefficients calculated from aquifer tests ranged from 0.00015 to 0.014 with an average value of 0.0002 . Aquifer 1 hydraulic conductivity, calculated from specific-capacity data, ranged from 3.5 to $160 \mathrm{ft} / \mathrm{d}$ with a geometric mean of $10 \mathrm{ft} / \mathrm{d}$. Transmissivity values from aquifer tests better represented aquifer 1 than did the geometric mean value for hydraulic conductivity. Therefore, zoned hydraulic conductivity values ranging from 2.5 to 8.2 $\mathrm{ft} / \mathrm{d}$ were used in the calculation of model input transmissivity values. The storage coefficients calculated from aquifer tests ranged from 0.00015 to 0.014 with an average value of 0.0002 .

Confining bed 4 acts as an upper confining unit for the underlying artesian bedrock aquifers. Vertical hydraulic conductivities calculated from aquifer tests and estimated by other researchers for confining bed 4 ranged from 0.0007 to $0.58 \mathrm{ft} / \mathrm{d}$. A vertical hydraulic conductivity of $0.007 \mathrm{ft} / \mathrm{d}$ was assigned to represent confining bed 4 in northeastern Wisconsin. The vertical hydraulic conductivity calculated from aquifer tests and estimated by other researchers for confining bed 3 ranged from 0.000007 to $0.0034 \mathrm{ft} / \mathrm{d}$. The vertical hydraulic conductivity assigned values of 0.0001 to $0.000004 \mathrm{ft} / \mathrm{d}$ for confining bed 3 in northeastern Wiscon$\sin$. There is no data available on the vertical hydraulic conductivity of confining bed 2 ; however, through a series of model calibration adjustments, a value of $0.00001 \mathrm{ft} / \mathrm{d}$ was found to give acceptable results. Confining bed 1 is a lower boundary of the aquifer system and was not modeled.

The model of the bedrock aquifer system in northeastern Wisconsin was used to aid in the evaluation of the regional flow system and the determination of the regional effects on the system due to ground-water withdrawals. The transient model in which pumping began in 1895 indicates that, by 1914, ground-water withdrawals had already affected the aquifer system. Pumping in and near the city of Green Bay had lowered the model-computed prepumping potentiometric heads as much as $69 \mathrm{ft}$ in aquifer 1 and $55 \mathrm{ft}$ in aquifer 2 .

The greatest impact on the aquifer system due to increasing pumpage had occurred by 1957 . The potentiometric heads of aquifers 1 and 2 indicate that pumping centered in and near the city of Green Bay, along with smaller pumping centers in the lower Fox River Valley, had affected most of the study area. The direction of ground-water flow, which had been generally to the northeast under prepumping conditions, was now controlled primarily by a large cone of depression centered in and near the city of Green Bay. Much of the water that formerly flowed out of the study area was now being captured by the cone.

With the exception of the city of Green Bay, which in 1957 converted to surface water (Lake Michigan) for their primary water supply, the ground-water withdrawals in the study area have generally increased. The model-computed composite potentiometric surface for aquifers 1 and 2 in 1981 shows that the large cone of depression centered in the city of De Pere area extends southwest up the Fox River Valley to Lake Winnebago. A small cone of depression also has developed in and near the city of Fond du Lac. The lowest potentiometric heads in the study area are present in and near the city of De Pere. The lowest value for the computed composite potentiometric surface of aquifers 1 and 2 is $425 \mathrm{ft}$ above sea level. The 1981 computed potentiometric head is $402 \mathrm{ft}$ above sea level and the head in aquifer 2 is $462 \mathrm{ft}$ above sea level.

The 1981 computed drawdowns (below the computed prepumping potentiometric surfaces in aquifer 1) ranged from 
$0 \mathrm{ft}$ on the western side of the study area to $330 \mathrm{ft}$ in the center of the cone of depression in the city of De Pere area. In aquifer 2, the computed drawdown ranged from $0 \mathrm{ft}$ on the western side of the study area to $253 \mathrm{ft}$ in the center of the cone.

The recharge-discharge relationships between aquifers 1 and 2 and aquifers 2 and 3 have changed significantly since prepumping conditions. The most significant changes occurred in the lower Fox River Valley area between Lake Winnebago and Green Bay. In this area potentiometric head reversals in aquifers 1 and 2 have caused an area that discharged under prepumping conditions to become a recharge area.

Although thousands of well records and water-level measurements were available, the assignment of the data to individual aquifers in the regional aquifer system was difficult. Some areas had no acceptable hydrologic data available while at other locations the data tended to be clustered. As a result, the traditional calibration process of matching contours of observed and computed data could not be used. The calibration process consisted of visually checking the validity of the computed potentiometric contours against the discrete water-level data points. Because there is no accurate prepumping water-level data and incomplete transient waterlevel data, calibration was achieved by a trial-and-error method of adjusting the hydrologic input elements to obtain both a steady-state model that had a reasonable set of starting heads and also acceptable potentiometric surfaces at the end of three transient-model pumping periods. The smallest average arithmetic and absolute differences between the steady-state model and the three transient calibration periods and the measured water levels was also used as a quantitative indication of the model's ability to duplicate measured historical water-level data.

Caution must be observed when using the model to predict future changes in the aquifer system due to anticipated changes in stresses. The model source program does not include an option to convert from artesian to water-table conditions if the potentiometric heads are lowered below the tops of aquifers 1,2 , or 3 . This could lead to erroneous results. If the water-table conversion is needed, the source program must be modified. Due to the extent of the large cone of depression in the modeled area, the predictive model boundaries should be checked to determine whether drawdowns occur at the boundaries. If such drawdowns do occur, their effect on model calculations must be evaluated to avoid unacceptable error.

The study area was modeled by use of a quasi threedimensional model that does not consider storage of water in the confining beds. The release of stored water from the confining beds would result in changes in the computed aquifer surfaces, especially on the eastern side of the study area. There are no data available on storage in the confining beds in the study area. Also, there is no data on the potentiometric surfaces on the eastern side of the study area to determine if the potentiometric surfaces as modeled are correct.

\section{REFERENCES CITED}

Bennett, G. D., 1979, Regional ground-water systems analyses: Water Spectrum, v. 11, No. 4.

Bennett, G. D., Kontis, A. L., and Larson, S. P., 1982, Representation of multiaquifer well effects in threedimensional ground-water flow simulation: Ground Water, v. 20 , no. 3 , p. 334-341.

Bradbury, K. R. 1982, Hydrogeologic relationships between Green Bay of Lake Michigan and onshore aquifers in Door County, Wisconsin: Madison, University of Wisconsin, unpublished Ph.D. thesis.

Brown County Planning Commission, 1979, Brown County water plan evaluation and update: Brown County Planning Commission, Green Bay, Wisconsin, 154 p.

Csallany, S., and Walton, W. C., 1963, Yields of shallow dolomite wells in northern Illinois: Illinois State Water Survey Report of Investigation 46, 43 p.

Donohue and Associates, Inc., 1976, Brown County water plan: Donohue and Associates, Sheboygan, Wisconsin, $206 \mathrm{p}$.

1977, Brown County water plan update: Donohue and Associates, I Sheboygan, Wisconsin, 15 p.

Drescher, W. J., 1953, Ground-water conditions in artesian aquifers in Brown County, Wisconsin: U.S. Geological Survey Water-Supply Paper 1190, 49 p.

Foley, F. C., Walton, W. C., and Drescher, W. J., 1953, Ground-water condtions in the Milwaukee-Waukesha area Wisconsin: U.S. Geological Survey Water-Supply Paper 1229, 96 p.

Freeze, R. A., 1972, Regionalization of hydrogeologic parameters for use in mathematical models of ground water flow: 24th International Geology Congress Proceedings, sec. 11, p. 177-190.

Gonthier, J. B., 1975, Ground-water resources of Waukesha County, Wisconsin: Wisconsin Geological and Natural History Survey Information Circular 29, 47 p.

Knowles, D. B., 1964, Ground-water conditions in the Green Bay area, Wisconsin, 1950-60, U.S. Geological Survey Water-Supply Paper 1669-J, 37 p.

Knowles, D. B., Dreher, F. C., and Whetstone, G. W., 1964, Water resources of the Green Bay area, Wisconsin: U.S. Geological Survey Water-Supply Paper 1499-G, 67 p.

Kontis, A. L., and Mandle, R. J., 1980, Data-base system for northern Midwest I Regional Aquifer-System Analysis: U.S. Geological Survey Water-Resources Investigations Report 80-104, 23 p.

Krohelski, J. T., 1983, Ground-water resources and geology of Brown County with a ground-water flow model for the lower Fox River Valley, Wisconsin: University of 
Wisconsin-Extension, Geological and Natural History Survey Information Circular No. 57.

Lohman, S. W., 1972, Ground-water hydraulics: U.S. Geological Survey Professional Paper 708, 70 p.

Newport, T. G., 1962, Geology and ground-water resources of Fond du Lac County, Wisconsin: U.S. Geological Survey Water-Supply Paper 1604, 52 p.

Oakes, E. L., and Hamilton, L. J., 1973, Water resources of Wisconsin-Menominee-Oconto-Peshtigo River basin: U.S. Geological Survey Hydrologic Investigations Atlas HA-470.

Olcott, P. G., 1966, Geology and water resources of Winnebago County, Wisconsin: U.S. Geological Survey Water-Supply Paper $1814,61 \mathrm{p}$.

1968, Water resources of Wisconsin-Fox-Wolf River basin: U.S. Geological Survey Hydrologic Investigations Atlas HA-321.

Skinner, E. L., and Borman, R. G., 1973, Water resources of Wisconsin-Lake Michigan basin: U.S. Geological Survey Hydrologic Investigations Atlas HA-432.

Steinhilber, W. L., and Young, H. L., 1979, Plan of study for the northern Midwest Regional Aquifer-System Analysis: U.S. Geological Survey Water-Resources Investigations 79-44, 20 p.

Trescott, P. C., 1975, Documentation of finite-difference model for simulation of three dimensional ground-water flow: U.S. Geological Survey Open-File Report 75-438, 32p.

Trescott, P. C., and Larson, S. P., 1976, Documentation of finite-difference model for simulation of threedimensional ground-water flow: U.S. Geological Survey Open-File Report 76-591 (supplement to open-file report 75-438).

Walton, W. C., 1960, Leaky aretsian aquifer conditions in Illinois: Illinois State Water Survey Report of Investigation $39,27 \mathrm{p}$.

Weidman, Samuel, and Schultz, A. R., 1915, The underground and surface water supplies of Wisconsin: Wisconsin Geological and Natural History Survey Bulletin 35, 664 p.

Wisconsin Bureau of Sanitary Engineering, 1935, Public water supplies of Wisconsin: $31 \mathrm{p}$.

Wisconsin Department of Natural Resources, 1970, Public water supply data, 1970: $101 \mathrm{p}$.

Young, H. L., 1976, Digital-computer model of the sandstone aquifer in southeastern Wisconsin: Southeastern Wisconsin Regional Planning Commission Technical Report No. 16, Waukesha, Wisconsin, 42 p.

Young, H. L., and Batten, W. G., 1980, Ground-water resources and geology of Washington and Ozaukee Counties, Wisconsin: Wisconsin Geological and Natural History Survey Information Circular No. 38, 37 p. 